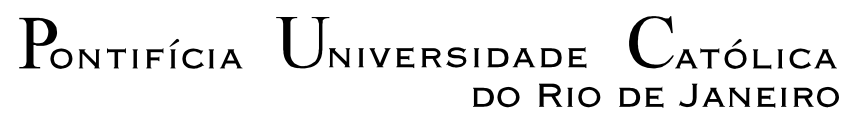

DO RIO DE JANEIRO

Maria Antonieta Sampaio Rodrigues

\title{
A LITERATURA NA FORMAÇÃO CULTURAL: A LITERATURA COMO MEDIADORA
}

Dissertação de Mestrado

Dissertação apresentada ao Programa de PósGraduação em Literatura, Cultura e Contemporaneidade da PUC-Rio como requisito parcial para obtenção do título de Mestre em Letras/Literatura, Cultura e Contemporaneidade.

Orientadora: Profa. Eliana Lucia Madureira Yunes 


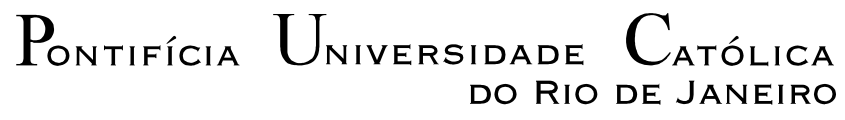

DO RIO DE JANEIRO

Maria Antonieta Sampaio Rodrigues

\section{A LITERATURA NA FORMAÇÃO CULTURAL: A LITERATURA COMO MEDIADORA}

Dissertação apresentada como requisito parcial para obtenção do grau de Mestre pelo Programa de Pós-Graduação em Literatura, Cultura e Contemporaneidade do Departamento de Letras do Centro de Teologia e Ciências Humanas da PUC-Rio. Aprovada pela Comissão Examinadora abaixo assinada.

Profa. Eliana Lucia Madureira Yunes

Orientadora

Departamento de Letras - PUC-Rio

Profa. Nanci Gonçalves da Nóbrega

UFF

Prof. Santinho Ferreira de Souza

UFES

Profa. Denise Berruezo Portinari

Coordenadora Setorial do Centro de Teologia

e Ciências Humanas - PUC-Rio

Rio de Janeiro, 11 de abril de 2013. 
Todos os direitos reservados. É proibida a reprodução total ou parcial do trabalho sem a autorização da universidade, da autora, e da orientadora.

\section{Maria Antonieta Sampaio Rodrigues}

Graduou-se em Letras pela UERJ, Universidade do Estado do Rio de Janeiro, com habilitação em Português e Inglês em 1982. Pós-graduação em Literatura Brasileira Contemporânea pela UERJ em 1983 e Filosofia pela UBM Universidade de Barra Mansa em 2005. Atualmente, é mediadora de leitura na Biblioteca Parque de Manguinhos e participa como oficineira do projeto Segundo Turno Cultural em Escolas do Amanhã pela Secretaria de Cultura da cidade do Rio de Janeiro.

\section{Ficha Catalográfica}

Rodrigues, Maria Antonieta Sampaio

A literatura na formação cultural : a literatura como mediadora / Maria Antonieta Sampaio Rodrigues ; orientadora: Eliana Lucia Madureira Yunes. - 2013.

168 f. : il. (color.) ; $30 \mathrm{~cm}$

Dissertação (mestrado)-Pontifícia

Universidade Católica do Rio de Janeiro, Departamento de Letras, 2013.

Inclui bibliografia

1. Letras - Teses. 2. Leitura. 3. Mediação. 4. Leitor. 5. Formação cultural. I. Yunes, Eliana Lucia Madureira. II. Pontifícia Universidade Católica do Rio de Janeiro. Departamento de Letras. III. Título. 
Esta dissertação é dedicada à grande companheira e amiga, Lêda Maria da Fonseca, que com seu trabalho, contribuiu de forma efetiva para a educação e cultura de tantas crianças e jovens. 


\section{Agradecimentos}

Agradeço os escritores pelas possibilidades que através das belas formas polissêmicas de escrita contribuíram para meu imaginário; os professores que com seu exemplo de estudo, dedicação e coerência foram fonte inspiradora para continuar aprofundando meus conhecimentos; os alunos que a cada instante aprendo a validade da arte/literatura como legado de vida melhor.

Eu também agradeço minha família por ter podido me proporcionar base e continuar apoiando meu crescimento intelectual e pessoal. Ter essa base, fez-me forte para a cada manhã eu tentar ser um melhor ser humano em casa, no trabalho, na comunidade, enfim por onde eu for.

A meus pais, mestres, companheiros e filho que nunca saberão o que lhes devo.

A vocês as palavras mais agradecidas. 


\section{Resumo}

Rodrigues, Maria Antonieta Sampaio; Yunes, Eliana Lucia Madureira. A Literatura na Formação Cultural: a literatura como mediadora. Rio de Janeiro, 2013. 168p. Dissertação de Mestrado - Departamento de Letras, Pontifícia Universidade Católica do Rio de Janeiro.

Esta dissertação de mestrado tem por objetivo analisar as oficinas literárias, integradas ao projeto do Segundo Turno Cultural, promovidas pela Secretaria de Cultura em parceria com a Secretaria de Educação nas Escolas do Amanhã da cidade do Rio de Janeiro, inseridas num contexto maior, previsto no PNLL (Plano Nacional do Livro e Leitura). O projeto Segundo Turno Cultural oferece no contra turno oficinas culturais para escolas em área de risco na cidade do Rio de Janeiro. A condição de acontecer dentro do ambiente escolar, faz com que seja pertinente a verificação do trabalho de leitura de textos literários realizado pelas oficinas. A pesquisa trata dos leitores considerando as políticas públicas do livro e leitura; seguindo para questão da mediação da leitura literária e a formação do leitor no espaço escolar. A experiência literária das oficinas como possibilidade para entender o mundo e relacionar-se em diferentes contextos sociais.

\section{Palavras-chave}

Leitura; mediação; leitor; formação cultural. 


\section{Abstract}

Rodrigues, Maria Antonieta Sampaio; Yunes, Eliana Lucia Madureira (Advisor). The reading on cultural formation: literature as a mediator. Rio de Janeiro, 2013. 168p. MSc. Dissertation - Departamento de Letras, Pontifícia Universidade Católica do Rio de Janeiro.

My study aims to analyze the literary workshops, integrated to the project Second Cultural Shift, promoted by the Ministry of Culture in partnership with the Department of Education in the schools called "Escolas do Amanhã" located in Rio de Janeiro, embedded in a larger context, under PNLL (Book and Reading National Plan). The project Second Cultural Shift offers cultural workshops for schools in risk area in the city of Rio de Janeiro. The condition of moving within the school environment, makes it pertinent to check the work of literary reading texts held by the workshops. The research comes from readers considering public book and reading policy; following question to the mediation of literary reading and training the reader in school. The experience of literary workshops as possibility to understand the world and relate in different social contexts.

\section{Keywords}

Reading; mediation; reader; cultural formation. 


\section{Sumário}

Introdução - Entendendo o Contexto: o início da conversa

1. Focando Leitores: um olhar sobre as políticas públicas 20

1.1. Um cenário das políticas públicas de leitura 21

1.2. Centro Regional para Fomento do Livro na América Latina e Caribe - CERLALC e Plano Nacional do Livro e Leitura - PNLL

2. Leitura Literária 34

2.1. A escola 34

2.2. Escola, espaço de troca cultural 41

2.3. Fruição mediadora e suas conduções 43

$\begin{array}{lll}\text { 2.4. O Leitor } & 48\end{array}$

3. Observação das Oficinas de Leitura 52

3.1. Escola Coronel José Gomes Moreira 55

3.2. Escola Ayrton Senna 64

3.3. Escola Júlia Lopes de Almeida 72

4. Testemunhando uma Prática de Mediação 81

4.1. CIEPs Teotônio Vilela e Hélio Smidt 81

4.2. CIEPs Chanceler Willy Brandt e Coronel Sarmento 89

4.2.1. Comunidade da Maré 96

5. Tempo que se esgota, sem fim de papo 105

6. Referências Bibliográficas 111

$\begin{array}{lll}\text { 7. Anexos } & 115\end{array}$ 


\section{Lista de Abreviaturas}

\begin{tabular}{ll} 
ANL & Associação Nacional de Livrarias \\
CBL & Câmara Brasileira do Livro \\
Cerlalc/ & Rede de Dirigentes de Planes de Lectura \\
UNESCO & \\
CIBEC & Centro de Informação e Biblioteca em Educação \\
CSLLL & Câmara Setorial do Livro, Literatura e Leitura \\
FNDE & Fundo de Desenvolvimento da Educação \\
FNILJ & Fundação Nacional do Livro Infanto-juvenil \\
IBGE & Instituto Brasileiro de Geografia e Estatística \\
IDEB & Índice de Desenvolvimento da Educação Básica \\
IEE & Índice de Efeito Escola \\
INEP & Instituto Nacional de estudos e Pesquisas Educacionais \\
INLLL & Anísio Teixeira \\
Instituto Nacional do Livro, Leitura e Biblioteca & Ministério da Educação \\
MinC & Ministério da Cultura \\
NAPRO & Núcleo de Atividades do Projeto Rondon \\
OEI & Organização dos Estudos Íbero-americanos \\
PDDE & Programa Dinheiro Direto na Escola \\
PELL & Plano Estadual de Livro e Leitura \\
PMLL & Plano Municipal de Livro e Leitura \\
PNBE & Programa Nacional Biblioteca Escolar \\
PNC & Plano nacional da Cultura \\
PNLD & Programa Nacional do Livro Didático \\
\hline
\end{tabular}


PNLEM Programa Nacional do Livro Didático

PNLL Plano Nacional de Livro e Leitura

PROLER Programa Nacional de Incentivo à Leitura

SAEB Sistema Nacional de Avaliação da Educação Básica

SEB Secretaria de Educação Básica

SEED Secretaria de Educação a Distância

SINAES Sistema nacional de Avaliação da Educação superior

SME-RJ Secretaria Municipal de educação do Rio de Janeiro

Snel Sindicato Nacional dos Editores de Livros

UNICEF Fundo Nacional das Nações Unidas 
A verdadeira educação consiste em obter o melhor de si mesmo. Que outro livro se pode estudar melhor do que o da Humanidade?

Mahatma Gandhi 


\section{Introdução - Entendendo o Contexto: o início da conversa}

As discussões sobre a necessidade de uma revisão das práticas de leitura literária na escola vêm ganhando corpo nos últimos anos. Cada vez mais, o modelo de comunicação escolar parece afastar-se dos processos comunicativos e artísticos que vêm transformando a sociedade contemporânea. Por um lado, o descentramento cultural pressiona na direção de interações permanentes, com simultaneidade de vozes e textos, em especial os que não dependem de alguma autoridade como transmissora de conhecimento. Por outro lado, o contexto contemporâneo é pouco considerado no eixo pedagógico, que não lança mão dos acervos pessoais e coletivos já disponíveis, isolando-se do sistema social.

Obras de arte não têm sentido estático, universal, fixo. Elas estão investidas de significações plurais e móveis, que se constroem no encontro de uma proposição com uma recepção. No entanto, as práticas pedagógicas tradicionais parecem impedir que esse encontro se dê livremente. A apropriação da literatura pela escola, denominada escolarização da literatura, por Magda Soares (2001), a socialização da leitura e outras estratégias de abordagem do texto literário são as questões que movem esta dissertação de mestrado.

A desescolarização da leitura, afastando as estruturas muitas vezes rígidas das práticas escolares, trata a leitura pelo viés da arte, deixando que o leitor se deleite com o texto livremente, que se envolva de espírito e corpo com a leitura, dando mais valor a diferentes sensações, sentimentos, emoções e desejos do que a ensinamentos, informações e conteúdos curriculares. As práticas escolares costumam afastar o aluno da literatura, mas quando a leitura é desescolarizada pode despertar seu interesse.

Atuei como professora de leitura e literatura nas redes pública e privada, lecionando na segunda fase do Ensino Fundamental e no Ensino Médio. Atualmente, sou oficineira de literatura do projeto Segundo Turno Cultural, realizado pela Secretaria de Cultura em parceria com a Educação da prefeitura do Rio de Janeiro, através da Coordenadoria de Arte e Educação, Livro e Leitura. O projeto se insere no Plano Nacional de Livro e Leitura (PNLL) atende, desde 2009, escolas de periferia que apresentam baixa média de rendimento escolar. 
Atuo no projeto Segundo Turno Cultural desde 2011, ministrando a oficina Literatura em Rede nas escolas Teotônio Vilela (na comunidade da Maré), Coronel Sarmento (comunidade do Alemão) e Chanceler Willy Brandt (comunidade do Jacaré). Partindo dessa experiência recente, escolhi focar minha dissertação de mestrado nessas três oficinas que ministro e, também, em três outras que já ocorrem há quatro anos ministradas por outros especialistas.

O objetivo central é verificar a eficiência do trabalho com o texto literário como estimulador de experiência cultural e seu aspecto artístico na formação do leitor. Para isso, investiga-se a ligação das oficinas de literatura com o espaço escolar e as transformações ocorridas nas escolas atendidas por essas oficinas, especificamente, no que diz respeito ao interesse dos alunos pela leitura literária e seus desdobramentos em atividades intelectuais e artísticas. Quais os procedimentos facilitadores presentes nas referidas oficinas para a formação de leitores críticos em texto e imagem?

Minha pesquisa tem apoio da Secretaria de Cultura que, atenta às expectativas no contexto das políticas públicas, entende ser necessário avaliar o projeto com instrumentos rigorosos, verificando os procedimentos que estão trazendo resultados positivos. Trazer elementos concretos para discutir as próximas etapas do funcionamento das oficinas é o propósito último. Acredito que, a partir da identificação desses procedimentos, será possível um direcionamento mais conveniente e produtivo das práticas das oficinas para garantir a presença do texto literário como construção da identidade cultural dos alunos.

A tarefa de observação crítica das atividades das oficinas pesquisadas busca o possível crescimento do interesse dos participantes nas atividades escolares em geral e na convivência social dentro e fora da escola. Supõe-se a possibilidade de resgatar, no comportamento dos integrantes da oficina, a partir da gradual consolidação de hábitos de leitura, uma crescente perspicácia na interação com a família, os amigos e as instituições que fazem parte de seu cotidiano. A atenção inventiva exigida, em especial, pela leitura de textos literários (adequados à faixa etária dos participantes) deve resultar num processo de desenvolvimento da capacidade crítica desses jovens diante de outros objetos culturais e das diversas experiências de vida que se lhes apresentam. 
Para o desenvolvimento deste projeto, coube considerar dois conceitos operacionais básicos: leitura literária e leitor crítico. De maneira geral, "leitura literária" seria a leitura de obras literárias com discurso capaz de absorver outras formas de linguagem que demonstram capacidade de reconfigurar a atividade humana, oferecendo instrumentos para compreender-se e compreendê-la. A obra literária agiria como uma convocatória para opinião e mais envolvimento do leitor, buscando comprometimento com a reflexão. Como a literatura se relaciona com outras formas de linguagem, assistimos a adaptações para cinema, televisão e teatro. A relação com outras linguagens nos coloca predispostos a interagir mais. Bom exemplo disso é a excelente adaptação da coleção Harry Porter para o cinema; dos romances Gabriela, Cravo e Canela, de Jorge Amado; Os Maias, do autor português Eça de Queiroz, para séries literárias na televisão.

"Leitores críticos" seriam alunos em condições de analisar o gênero do texto, recursos de expressão e de recriação da realidade, percepção do narrador, personagens, ponto-de-vista, interpretar analogias, comparações, metáforas, além de identificar recursos estilísticos e poéticos. O leitor crítico se torna um cidadão mais exigente, constrói imaginário pessoal, identifica clichês e estereótipos, tomando a literatura de ficção como fonte de reflexão pessoal, indispensável para construção de um homem mais inventivo/criativo.

A reflexão cuidadosa sobre os dados observados no comportamento das crianças indicará, certamente, os procedimentos adequados ao funcionamento do âmbito escolar a partir das oficinas e aqueles outros cuja eficiência não se desenhe, apresentando a necessidade de revisão. A dissertação de mestrado justifica-se, então, não apenas pelos questionamentos teórico-críticos que levanta mas, em especial, pela possibilidade de tornar-se um apoio para melhor desenvolvimento das práticas leitoras nas oficinas e posteriormente nas salas de aula.

A proposta do Segundo Turno Cultural, de que falarei melhor adiante, tenta romper com a concepção da escolarização da literatura, determinada e orientada pelo professor como tarefa ou dever escolar, que acaba por afastar as crianças do texto e desenvolve resistência ou até mesmo aversão à leitura. Observando a situação atual do projeto, pergunta-se: será que as oficinas de literatura conseguem trazer o leitor para a experiência ímpar, porque única, que o 
texto literário possibilita ou todo trabalho que se efetua dentro da escola se escolariza?

A análise crítica das atividades propostas e desenvolvidas pelas oficinas, com suas peculiaridades e com diferentes históricos de funcionamento, deve apontar para o maior ou menor interesse que desperta nas crianças, além de revelar as potencialidades sensíveis e intelectuais que ativam em seus participantes, inserindo-os no mundo imaginário da literatura, em cuja estrutura simbólica pode-se projetar, estabelecendo um diálogo entre os textos lidos e os vários aspectos da cultura. Em geral, será que o esforço de ler nas oficinas contribui para uma aproximação do aluno com a literatura? Propõe-se essa pergunta porque a experiência literária, ao aguçar as percepções e agilizar o raciocínio, pode ampliar a capacidade de entender o mundo e interagir socialmente.

A primeira etapa da dissertação fica centrada no entendimento das políticas públicas cuja prioridade é transformar e diversificar a atividade leitora do Brasil e trazer a leitura para o dia a dia dos cidadãos brasileiros. Para tal, foram coletados dados sobre o PNLL, e seus desdobramentos: Plano Estadual de Livro e Leitura (PELL) e Plano Municipal de Livro e Leitura (PMLL), que articulam um conjunto de projetos, programas, atividades e eventos na área do livro, leitura, literatura e bibliotecas em desenvolvimento no país, num empreendimento de governo (em âmbito federal, estadual e municipal). O PMLL do Rio de Janeiro conduzido pelas secretarias de Educação e Cultura ainda está em processo de elaboração e o Plano Estadual de Cultura, Livro, Leitura, Bibliotecas está sendo construído, disponível na internet a partir de agosto de $2012^{1}$.

A intervenção do Estado na promoção da leitura por meio de políticas públicas deve-se à premência de formar leitores, através de textos literários e não literários, para uma participação mais efetiva na sociedade do século XXI. O primeiro capítulo, intitulado Focando Leitores: um olhar sobre as políticas públicas, procura mostrar a importância que a leitura assume no mundo atual a partir da criação de políticas públicas para a América Latina e Caribe, o Brasil e a cidade do Rio de Janeiro.

\footnotetext{
${ }^{1}$ http://www.cultura.rj.gov.br/materias/livro-leitura-e-bibliotecas-entram-em-debate-no-planoestadual-de-cultura. Acesso em: 25 jan. 2013.
} 
Em artigo publicado no jornal O Globo de 1/1/2011, caderno Prosa e Verso, no dia da posse da atual presidente do Brasil, Eliana Yunes escreve um artigo sobre o atual panorama da educação no país que Dilma Rousseff começava a governar. O resultado do PISA que mede o desempenho de estudantes de 65 países, publicado em dezembro de 2010, indica que estamos no quinquagésimo terceiro lugar, com um avanço de $4 \%$ em relação a nove anos atrás, o que poderíamos entender como melhora. “(...) contudo, seguem as taxas de repetência altas, escolas isoladas, formação sofrível do mediador", diz o artigo. Os países que melhoraram seus índices aumentaram o investimento na educação infantil, na escola básica e na formação continuada de professores.

O MEC propõe no Plano Nacional de Educação (PNE), implementar a qualidade da formação de professores e alunos, numa tentativa de acompanhar individualmente as crianças, recomendação dada pela Unesco para a próxima década. Esforço contínuo para reduzir a evasão escolar, a repetência e a distorção entre série/idade, aumentar a taxa de matrícula na pré-escola e conclusão do ensino fundamental. "O PNE precisa mais que 7\% para acelerar metas que universalizem o ensino (hoje 91\%) e chegue a ter 95\% dos alunos com fundamental completo correspondendo em idade aos anos de estudo (hoje, 63\%); e no ensino médio alcançar $90 \%$ frente aos atuais $50 \%$ no número dos que concluem, no fim da década."

$\mathrm{Na}$ segunda etapa, trato das categorias que envolvem minha prática e minha observação: o estudo da literatura na escola, mediação, formação de leitores e projetos culturais com textos literários.

Na última etapa, o foco é a observação e análise de oficinas de literatura do projeto Segundo Turno Cultural, existente desde 2009 na cidade do Rio de Janeiro, e que fazem parte do PNLL. Durante seis meses, acompanhei as oficinas Encontros de Leitura e Ateliê de Histórias, a primeira no morro dos Prazeres, em Santa Teresa, e a segunda nas comunidades de Vila Aliança e Vila Kennedy. Dediquei-me, ainda, à leitura e análise das propostas dos dois oficineiros responsáveis. O relato de minha própria experiência como oficineira nas comunidades da Maré, do Alemão e do Jacaré complementa a pesquisa, com diferentes programas de oficinas: Experiências no Labirinto e Literatura em Rede.

As atividades do projeto Segundo Turno Cultural são opções oferecidas aos alunos que se inscrevem livremente, mas não há uma obrigatoriedade em 
cursar, o que dificulta ver resultados. Propõe-se para além do "primeiro turno educacional", em que a literatura e mesmo a leitura não encontram espaço privilegiado de desenvolvimento, fundamental para todo e qualquer aprendizado. Antes dos "conteúdos", é preciso entender as formas e os meios pelos quais são apresentados: a leitura é o veículo do conhecimento por excelência (leitura de todo e qualquer material, mundo ou letra) e a literatura, a provocação da palavra artística para lidar com o pensamento crítico, com as percepções, desentendimento, apropriações do mundo em redor e da história em que se insere a vida de cada sujeito.

O Segundo Turno Cultural foi, pois, criado para proporcionar mais oportunidades de formação cidadã por apropriação das variantes culturais e suas expressões. O projeto tem como princípio estabelecer um vínculo entre a vivência escolar e a cultura do território onde a escola está situada. Para isso, as oficinas culturais e artísticas - abrangem diversas linguagens além da literária. São realizadas atividades de teatro, dança, música, audiovisual, artes visuais, circo, entre outras. Em 2011, foram atendidos 19.143 alunos em 153 escolas, das quais apenas três não se situam em áreas de risco.

O projeto integra o programa Escolas do Amanhã, criado em 2009 pela Secretaria Municipal de Educação do Rio de Janeiro (SME-RJ) com o objetivo de reduzir a evasão escolar e melhorar a aprendizagem em escolas do ensino fundamental situadas em áreas de risco social. Segundo Lucas (2011):

\footnotetext{
O projeto Escolas do Amanhã faz parte do programa institucional do Município do Rio de Janeiro, denominado Bairro Educador, pela demarcação de ações positivas nessas áreas conflagradas, através de um foco coletivo que procura enfrentar os problemas dessas comunidades, que também são chamadas a atuar conjuntamente com escolas, a fim de fortalecer o vínculo entre a presença da própria família, ao aproximá-las do cotidiano escolar. (p. 21)
}

Além de envolver os alunos em atividades de educação, arte e cultura, o programa atua nas áreas de saúde, assistência social, esporte. As crianças devem permanecer nas escolas em tempo integral, contando com reforço escolar e outros diferenciais. A SME-RJ propõe mudanças estruturais, operacionais e curriculares. O modelo de gestão estabelece parcerias com a iniciativa privada e a comunidade sem fins lucrativos. Existe um coordenador das Escolas do Amanhã, que faz parte 
da comunidade e é responsável pela interface escola/comunidade. Ele recebe um salário mensal do programa Mais Educação do MEC. A metodologia usada é a mesma que foi aplicada em regiões da África, como Angola, Etiópia, Quênia, Sudão e Tanzânia.

As políticas de avaliação da SME-RJ se concentram nas seguintes provas: Prova Rio-resultados; IDEB-resultados; Aceleração 1, 2; Se Liga, Fórmula da Vitória; AlfaeBeto; Autonomia Carioca e Reforço Digital; todas essas propotas estão ligadas pela meta de qualidade em educação dessa rede. Meta cumprida após avaliação, os professores e funcionários recebem prêmio de um salário mínimo como gratificação.

Outro elemento importante a ser destacado é o programa Mais Educação, que assegura as verbas necessárias ao andamento operacional do projeto Escolas do Amanhã. Esse programa foi criado pela Portaria Interministerial no. 17/2007 e sua operacionalização se efetiva por meio do Programa Dinheiro Direto na Escola (PDDE), do Fundo Nacional de Desenvolvimento da Educação (FNDE). O programa Mais Educação fomenta projetos que buscam melhorias nas escolas da rede pública com ações na área da cultura, esporte, dos direitos humanos e do desenvolvimento social, mediante ampliação da jornada escolar.

O Fundo das Nações Unidas para Infância (Unicef) também corrobora com seus estudos na fundamentação da proposta das Escolas do Amanhã. Nesses estudos destaca-se o Índice de Efeito Escola (IEE), um indicador que avalia os impactos do processo de aprendizado na vida dos estudantes. Além disso, cruza informações socioeconômicas de cada município. Em decorrência desses fatores, é possível perceber que o programa Mais Educação prioriza o atendimento a escolas que apresentem baixos resultados do Índice de Desenvolvimento da Educação Básica (IDEB).

O IDEB mede a qualidade do ensino nas escolas em todo país. A partir de seus resultados definem-se políticas e estratégias que orientam as práticas educacionais nas escolas. A partir disso, o MEC transfere recursos para os municípios que apresentam projetos inovadores, como é o caso do projeto Escolas do Amanhã, onde ocorre o Segundo Turno Cultural.

O esforço do projeto vem ao encontro das escolhas que fiz: minha inquietação como professora e aluna, minha constante busca por caminhos que trouxessem alunos para o mundo do conhecimento e das artes. Muitas vezes ouvi 
dizer que, para fazer o aluno gostar de ler, basta que o professor seja um leitor apaixonado. Mas, na realidade, não é sempre assim. Sou leitora apaixonada e nem por isso consigo atrair todos os meus alunos para o hábito da leitura. Minhas tentativas, na maior parte das vezes frustradas, me deixavam sem ideia para um passo seguinte.

A professora de leitura e literatura foi se construindo na medida em que convivia com esses alunos, cada vez mais arredios ao texto escrito, principalmente ao texto literário. Assim, observava jovens e crianças voluntariamente privados de uma maior compreensão do entorno propiciada pela riqueza polissêmica do texto literário. O livro não atraía as crianças que eu ensinava, como me atraiu desde sempre.

Certamente o livro me modificou, a ponto de eu fazer dele um instrumento profissional. Fui me tornando uma mediadora de leitura que pretende contribuir para a formação da subjetividade e singularidade do sujeito, oferecendo textos diversos para a formação do repertório de cada aluno. A minha pretensão é que eles enxerguem o outro, a cultura do outro, os espaços, os personagens que vão construindo narrativas diversas, com possibilidades de leituras diversas também. A convivência com o diferente, o estranho, o estrangeiro, que a literatura possibilita, talvez auxilie na convivência entre as diversas facetas sociais. A literatura, assim como outras linguagens artísticas a ela associadas, seria capaz de resgatar o caráter sensível e poético do existir inerente ao ser humano. Mas como propiciar tudo isso ao aluno que se recusa a ler?

A necessidade de atividades lúdicas na escola para provocar interesse pela leitura, estimulando as trocas, as intertextualidades, instigando a capacidade de estabelecer analogias entre os vários sistemas de linguagem e envolver os alunos em práticas que sejam significativas para o entendimento dos textos e que façam ou construam sentido(s) para sua própria realidade foi o que me trouxe para o Segundo Turno Cultural. Agora, especificamente com este trabalho de pesquisa, pretendo discutir as estratégias do projeto da Prefeitura e avaliar como elas atendem a seu propósito inicial. 


\title{
Focando Leitores: um olhar sobre as políticas públicas
}

\author{
"Uma política pública se torna necessária quando há uma distância entre as aspirações e \\ as realizações." \\ Bruno Revez
}

A sociedade no século XXI necessita refletir sobre os empreendimentos em curso entre nós, países latino-americanos, no que tange as políticas públicas e as práticas de leituras ocorridas. Segundo estatísticas, cerca de $50 \%$ da população se encontra abaixo dos níveis de pobreza. Exige-se, portanto, uma intervenção comprometida na qual todos sejam respeitados e possam contar com uma posição digna. São necessárias mudanças significativas que ampliem o âmbito do conhecimento de modo a orientar a população para formação de leitores. Deve-se entender "leitor" como aquele que é capaz de ler tanto os textos quanto a realidade e, assim, sabendo situar-se socialmente, reivindicar seus direitos de cidadania.

$\mathrm{O}$ acesso à escolaridade e à leitura está na pauta de todas as agendas governamentais. Nunca se discutiu tanto a relação entre leitura e inserção social, vinculando a importância da leitura à escola e revelando o surgimento e o desenvolvimento de políticas públicas que se ocupam em tornar melhor as condições de letramento da população. Ao longo dos séculos e de acordo com os estágios e transformações pelos quais passaram as instituições e as técnicas de reprodução, a leitura experimentou diversas concepções, práticas, funções, modos e tipos de suporte. As deficiências do ensino, as contradições entre a teoria e a prática, os desapontamentos dos alunos e professores com a escola, o ensino de literatura aos moldes históricos e projetos de leitura que afastam alunos da leitura do texto literário não ajudam a história da modernização de nosso país.

Para conhecer e compreender as contradições do mundo capitalista globalizado, que exclui milhares de pessoas da participação social, é preciso recorrer aos documentos sobre as políticas públicas de leitura. A consciência do 
caráter político do ato de ler é importante para que o sujeito tenha uma atitude emancipada frente ao texto, entendendo-o como um produto e não como verdade.

Com uma perspectiva que procura reconhecer e valorizar as práticas de leitura, grandes esforços no setor público e privado vêm acontecendo para melhorar a formação de leitores e ampliar as possibilidades de acesso à cultura letrada em boa parte dos países da América Latina. No entanto a contradição nos programas de incentivo à leitura começa a se apresentar quando eles surgem da necessidade de setores ligados à produção do livro para ampliar o mercado em benefício exclusivo de seus próprios interesses desprovidos de todo poder crítico, portanto, de transformação social.

A promoção de instrumentos para ampliar sinapses mentais, como o livro e leitura, não se dá, a partir de campanhas e programas verticais, paternalistas, pois levam ao consumo acrítico sem despertar no cidadão autonomia de ação. Para tal melhorar a qualidade da educação faz-se necessário uma política com princípios de cidadania, comprometida com cada indivíduo e com a coletividade, onde leitura e escrita sejam protagonistas.

\section{1 Um cenário das políticas públicas de leitura}

Focando um olhar sobre as políticas públicas de leitura e formação de leitores, foi no governo de Getúlio Vargas, com Gustavo Capanema como Ministro da Educação, a criação do Instituto Nacional do Livro (INL), em 1937, que se promoveu uma política voltada para criação de bibliotecas públicas e fortalecimento do mercado editorial, desenvolvido àquela época. O Governo passou a comprar livros das editoras para doá-los às bibliotecas públicas. Paralelamente, passou a incumbir-se também da publicação de livros didáticos.

De 1938 a 1966, o foco no livro técnico e didático persiste, sendo fortalecido pelo acordo MEC-USAID, que garante três anos de distribuição gratuita de milhões de livros. Até 1985, decretos e acordos ora extinguem ora criam fundações, órgãos, sistemas e programas que valorizam tanto os livros técnicos e didáticos como beneficiam as editoras com incentivo à publicação de 
livros e desonerações fiscais. Com a criação do Programa Nacional do Livro didático (PNLD) pelo decreto no. 91.542, de 19/8/1985, e extinção do Programa do Livro Didático para Ensino Fundamental (Plidef), altera-se a participação dos professores no processo de escolha dos livros.

As iniciativas governamentais que sucederam durante a existência do INL (de 1937 até sua extinção, em 1990) com criação da Fundação Nacional do Livro Didático (Fename), em 1967, e o Programa Nacional do Livro Didático (PNLD), em 1985, foram baseadas na distribuição de livros didáticos e criação de bibliotecas públicas. Fundamentais e de grande valia foram essas iniciativas para o estímulo à leitura no Brasil. Mas poucas fugiram a esse modelo, implementando práticas novas. Somente a partir da década de 1970 veremos ações diferenciadas, advindas principalmente de iniciativas não governamentais, como a Fundação Nacional do Livro Infantil e Juvenil (FNLIJ) em 1968, uma instituição privada sem fins lucrativos, seção brasileira do International Board on Books for Young People - IBBY - órgão consultivo da Unesco que declara que o livro é um instrumento fundamental para o aperfeiçoamento humano, concebendo a leitura como um direito do homem, a ser garantido pelo Estado.

A FNLIJ, a partir de 1980, buscou atingir públicos antes esquecidos. Assim, criou minibibliotecas em comunidades, hospitais, fábricas e outros locais; investiu na formação de professores e bibliotecários; realizou oficinas, cursos, seminários; promoveu programas de leitura destinados às crianças que não freqüentavam a escola. Desenvolveu parcerias com diversas entidades públicas e privadas, realizando projetos como "A Ciranda de Livros" em parceria com a Hoescht e Fundação Roberto Marinho, que distribuiu livros e incentivou a literatura infantil e juvenil. A partir de 1974, estimulada pelo congresso do IBBY no Brasil, começou a desenvolver avaliação crítica da literatura infantil e juvenil e premiação anual. Hoje no Salão do Livro, criado em 1986, são premiadas as melhores obras publicadas, não se envolvendo tanto na questão da mediação da leitura.

Por falta de planejamento oficial, foram postas em prática as linhas políticas levantadas em pesquisa sobre leitura e sua promoção e com isto surgiu o Proler (1992) - um programa nacional de incentivo à leitura - um compromisso formal entre as autoridades e instituições locais com a fundação Biblioteca Nacional. 
Além das discussões que precedem ao início do Proler, outras aconteceram a partir dos encontros de capacitação para nortear ações básicas: criação de bibliotecas públicas; ampliação de seus acervos; reconhecimento da ação docente para os professores que se encontram à frente das salas de leitura e bibliotecas escolares; desburocratização de medidas para facilitar ao profissional tornar-se agente de leitura na saúde, transporte, serviço social, lazer; ativação de espaços para promoção da leitura, etc. ${ }^{2}$

O Proler, em sua atuação, partiu de hipóteses já levantadas na pesquisa desenvolvida, entre 1984 e 1989 para Finep, por um grupo de pesquisadores liderados pela professora Eliana Yunes, que estabeleceu alguns pressupostos teóricometodológicos acerca da leitura e que fundamentam os estudos atuais sobre o tema. Estes pressupostos definiram as diretrizes do programa então criado e valorizaram as seguintes dimensões da leitura:

- a leitura como atividade permanente da condição humana, quer se tenha ou não consciência dela; a leitura considerada, portanto, em sua dimensão semiótica e hermenêutica;

- a leitura como prática de vida que emerge com nossa leitura de mundo e da qual depende o domínio da linguagem verbal graficamente codificada;

- a leitura como experiência prazerosa, apurada no estreitamento das relações entre leitor, texto e contexto;

- a leitura como produção de subjetividades, por sua capacidade de afetar o sujeito, formando-o e transformando-o, enquanto "corpo social" e individual;

- a leitura como experiência de interação entre as vivências, a memória e o texto;

- a leitura como reflexão a desvelar as ideologias que subjazem os discursos;

- a leitura como experiência que percorre as diversas áreas do conhecimento e, nessa perspectiva não restrita ao início dos processos de escolaridade e alfabetização;

- a leitura na perspectiva de uma nova hermenêutica, considerando que a atividade da leitura do mundo - na ilusão das coisas tais como se apresentam aos indivíduos - conduz ao mundo da leitura - filtrada pela interpretação, com reflexos sobre as práticas sociais (Pellegrini, 2010).

O Proler sob a coordenação geral da pesquisadora Eliana Yunes de 1992 a 1996, buscou do ponto de vista político, um programa interministerial sob a responsabilidade da Biblioteca Nacional, envolver os diversos setores da população excluída, em especial crianças, jovens e suas famílias para um programa de incentivo à leitura, cuja meta era alcançar de modo gradual e estável um interesse nacional pró-leitura, capaz de suscitar na população em geral, desejo

\footnotetext{
${ }^{2}$ Retirado do documento Para entender a proposta do PROLER da Fundação Biblioteca Nacional - Ministério da Cultura, 1992.
} 
e pré-disposição para ler. Somaram-se iniciativas diversas, oficiais e de instituições não-governamentais para promover uma política de leitura por parte do Estado. Ainda não havia ocorrido na história da leitura do país uma proposta que abarcasse a base e todos os segmentos da sociedade, empreitada audaciosa e arrojada realizada pelo grupo.

Criar a consciência de que a leitura crítica é o fim último da escolaridade o que capacita o indivíduo à condição de exercer a cidadania com intercâmbio de experiências e informações contemplando também a comunidade e a família do aluno, era sua meta.

Os mecanismos básicos para sua atuação seriam:

- centro de estudos de leitura - grupos interescolares de formação permanente de professores através da familiarização com o livro e com a biblioteca, para atuação permanente;

- dinamização das bibliotecas escolares e salas de leitura através de um programa supervisionado de atividades e de distribuição de materiais com sugestão de atividades (orientação pedagógica). ${ }^{3}$

Proler com suas atividades e sua política pública de leitura compreende a importância e o valor que devem ser dados ao repertório cultural que nos constitui enquanto sujeitos - leitura como prática social. Não são os intelectuais os responsáveis por estruturar o Proler. A proposta é que ele seja construído por toda sociedade, sendo responsabilidade de todos. A leitura é vista como uma relação dialógica, troca de experiências que transforma em outras experiências.

A memória era um dos pilares do Proler. De grande importância, nesse sentido, foi o trabalho de resgate das histórias de leitura dos profissionais que participaram do programa. Os registros eram valorizados na medida em que iam construindo o material que formaria o Centro de Referência e Documentação do programa, criado na Casa da Leitura. Esse material representa a memória de uma geração de leitores e vem enriquecer o panorama da história da leitura no país.

A Casa da Leitura instituiu-se como um centro de promoção, de pesquisa e documentação da leitura. Registrava todas as experiências em leitura que estivessem acontecendo em todo o país. Era, também, um centro de referência criada com a intenção de fugir aos padrões de uma biblioteca tradicional; a

\footnotetext{
${ }^{3}$ Retirado do documento intitulado Anteprojeto para uma política na nacional de incentivo à leitura da Fundação Biblioteca Nacional, Política Nacional de Leitura, 1992.
} 
dinâmica do seu funcionamento disponibilizava seu acervo sem as formalidades de uma biblioteca. O acesso à leitura se dava através da Contação de Histórias, prática que se manteve, por todo o tempo de vida do Proler (1992-1996), dos espetáculos teatrais, das exposições, dos Encontros com Autores, da leitura em sua dimensão ampla semiótica e hermenêutica.

Em 2001, as mesmas diretrizes que orientaram a criação do Proler, em 1992, agora ampliadas pelas conquistas tecnológicas que a todo momento enriquecem a área das comunicações, foram responsáveis pela criação da Rede de Estudos Avançados de Leitura, na PUC-Rio. Esta daria origem à Cátedra Unesco de Leitura (2005), singularizada por ser a primeira e única na América Latina cujo objeto de estudos é a leitura. A Cátedra Unesco surge dos esforços de três departamentos da PUC-Rio, que, numa ação interdisciplinar, contribuíram para que se viabilizasse esta iniciativa: os pesquisadores das áreas de Artes, Educação e Letras, reuniram seus trabalhos para criar a instituição.

A Cátedra analisou os projetos de promoção da leitura inscritos no prêmio VivaLeitura, do MEC, nos anos de 2006 e 2007, mapeando estas ações em todo o território nacional. Orienta programas como o de "Agentes de leitura", do MinC. Abriga uma biblioteca de obras direcionadas a crianças e jovens, BLIJ, cujo acervo foi muito bem organizado, através de critérios especiais (Pellegrini, 2010).

O Programa Nacional de biblioteca da Escola (PNBE) e Fundo Nacional de Desenvolvimento da Educação (FNDE) têm promovido mudanças no cenário dos livros nas escolas públicas do Brasil uma vez que tem investido em livros de literatura, mas numa escala inferior em relação ao livro didático até hoje, uma vez que a todos os alunos das escolas públicas brasileiras é garantido anualmente o direito a volumes de livros didáticos, ao passo que os investimentos em livros de literatura são realizados segundo critérios que variam a cada edição do PNBE.

Ao longo da história do história do PNBE, a distribuição dos livros de literatura tem sido realizada por meio de diferentes ações: em 1998, 1999 e 2000, os acervos foram enviados para bibliotecas escolares, em 2001, 2002 e 2003, o objetivo era que os alunos tivessem acesso direto a coleções para uso pessoal e também levassem para seus familiares obras representativas da literatura nacional - por isso, essas edições do programa ficaram conhecidas como "Literatura em Minha Casa". A partir de 2005, após discussões coordenadas pela Secretaria de Educação Básica (SEB) do Ministério da Educação e Cultura (MEC), o PNBE 
retomou a distribuição de livros de literatura para bibliotecas escolares. Neste ano, direcionou suas atuações para bibliotecas das escolas públicas de $2^{\circ}$. a $5^{\circ}$. anos do Ensino Fundamental. Em 2006, foram distribuídos livros de literatura para as escolas públicas de $6^{\circ}$. a $9^{\circ}$. anos, pelo PNBE. Em 2008, as escolas das séries/anos iniciais foram contempladas. As remessas de cada edição do PNBE são de pequena quantidade de livros, quando se considera o que cada escola recebe. No entanto, os números são elevados, quando se consideram os acervos distribuídos pelo país.

O PNDL e PNBE se mantêm até hoje. Mais recentemente, foram criados o Programa Nacional do Livro Didático para Ensino Médio (PNLEM) através de resolução do FNDE, em resposta ao Plano Nacional de Educação (PNL), que determinou o fim do analfabetismos até 2011, e criou o Programa de Livro Didático para Alfabetização de Jovens e Adultos (PNLA), que doa livros a entidades que atuam em forma de parceria na alfabetização de pessoas acima de 15 anos.

\section{2 \\ Centro Regional para Fomento do Livro na América Latina e Caribe - CERLALC e Plano Nacional do Livro e Leitura - PNLL}

No final da década de 1960, através de diversos estudos elaborados por órgãos internacionais detecta-se que o acesso aos livros e aquisição da leitura estava diretamente relacionado com o desenvolvimento dos países. Por esta razão, a Unesco propôs a criação de uma comunidade internacional com organismos regionais que apoiassem os governos no que se referia às políticas de livro e leitura. Em 1971, em Bogotá, Colômbia, criou-se o Centro Regional para Fomento do Livro na América Latina e Caribe (CERLALC) ${ }^{4}$, encarregado de toda região latino americana.

\footnotetext{
${ }^{4}$ As informações sobre o CERLALC foram consultadas em http://www.cerlalc.org/files/comotrabajamos/354e20_Programa_T\%C3\%A9cnico_FINAL.pdf Acesso em 19 mar.2013.
} 
Os membros do CERLALC são todos os países ibero-americanos e o Caribe de línguas hispano-lusitana, sendo que Portugal foi o último país a aderir à convenção da Unesco em 2005.

Nos últimos 40 anos, CERLALC tornou-se referência essencial no mundo devido ao seu elevado nível de especialização e desenvolvimento técnico, bem como o seu apoio para os formuladores de políticas públicas para desenvolver ferramentas eficazes para avançar na construção de sociedades leitoras, incentivando através de mecanismos variados o respeito aos direitos do autor. Atualmente, nosso país é representado na entidade pela FBN e tem como consultora a professora Eliana Yunes.

Os parceiros naturais do CERLALC são os ministérios de cultura e educação dos países membros, bem como os responsáveis pelas políticas culturais. O Centro também presta serviços para organizações profissionais, instituições e entidades do setor privado, bem como para organizações da sociedade civil que trabalham em qualquer área relacionada à sua missão. O CERLALC apoia e orienta governos na concepção e implementação de política de leitura pública, especialmente no desenvolvimento de sistemas de bibliotecas públicas.

Também estimula o diálogo entre mercado editorial, de marketing e de leitura. No que diz respeito a criação intelectual, promove ações que vão desde incentivar a criatividade no sistema educacional até facilitar a formulação de políticas para garantir a segurança social para os autores, por meio do fortalecimento de instituições que garantam a protecção das obras.

Através de plataforma tecnológica, o CERLALC disponibiliza para comunidade latino americana, em espanhol e português, acesso amplo e democrático das estatísticas sobre a produção e comércio de livro, consolida a legislação comparada sobre o estado dos direitos autorais e autores na região, estudos sobre políticas de leitura e experiências nacionais de alfabetização e bancos de dados sobre o regulamentos de comercialização dos livros em cada país.

Igualmente promove treinamento para grupos com necessidades específicas, como livrarias, editoras e difusão de direitos autorais. O Centro participa da geração de conteúdo e promoção de melhores práticas que visam a construção de metodologias de conhecimento para mediadores de leitura, 
professores, bibliotecários e editores. Faz alianças com várias instituições para fortalecer projetos relacionados à proteção da criação intelectual, à promoção da produção e circulação de livros e promoção da leitura e escrita.

O Ministério da Educação e a Cultura (MEC), em razão do Plano Iberoamericano de Leitura (Ilímita), adotou desde o ano de 2005 o dever de promover, articular e divulgar todas ações em favor da leitura e a escrita, entendo-as como ferramentas de inclusão social e desenvolvimento, que no entanto não é identificado por pesquisadores no site do Ministério, em seu conjunto.

Neste contexto, o decreto do MEC é o de impulsionar uma política pública onde a leitura não deve ser entendida apenas como um problema pedagógico ou uma ação individual, e sim e acima de tudo, como um costume profundamente socializado, em constante evolução decorrente das mudanças que acontecem na sociedade. Durante vários anos, o CERLALC vem desenvolvendo ações a fim de garantir o sustento dos esforços feitos pelos países em matéria de leitura e escrita na educação básica e na formação de recursos humanos nas escolas.

O Ministério da Cultura (MinC) articulado com o Ministério da Educação (MEC), instituiu em 2006, o Plano Nacional do Livro e Leitura (PNLL), no governo do Presidente Lula, cujo embrião era o PROLER. É composto de centenas de ações, projetos, programas e políticas governamentais e da sociedade civil, onde a leitura e a escrita são percebidas como práticas essencialmente sociais e culturais, expressão da multiplicidade de visões de mundo, esforço de interpretação que se reporta a amplos contextos.

Quatro anos depois de transformado em lei, o PNLL foi reavaliado pela sociedade civil e governo. O governo federal propõe então, o Instituto Nacional do Livro, Leitura e Literatura (INLLL) para gerir as políticas públicas do livro e leitura. Paralelamente, inclui na reforma da Lei Rouanet um fundo setorial, dentre os oito criados no Fundo Nacional de Cultura (FNC). Mas o INLLL não saiu do papel, permanecendo uma Diretoria no MinC

O contexto em que se insere a Política do Estado está calcado em alguns pressupostos básicos sobre os quais se assenta o Plano, correspondem a uma tomada de posição conceitual em relação à leitura e ao livro. O livro deve ocupar destaque no imaginário nacional, sendo dotado de forte poder simbólico e valorizado por amplas faixas da população. 
O PNLL registra que a leitura e a escrita são percebidas como práticas essencialmente culturais com multiplicidade de visões de mundo e são duas faces diferentes, inseparáveis de um mesmo fenômeno. A leitura e a escrita constituem elementos fundamentais para a construção de sociedades democráticas, baseadas na diversidade, na pluralidade e no exercício da cidadania; são direitos de todos, são requisitos indispensáveis para alcançar níveis educativos mais altos; apresentam-se como condição necessária para o desenvolvimento social e econômico, constituindo condição básica para que cada indivíduo possa exercer seus direitos fundamentais e viver uma vida digna.

O Brasil chega ao século XXI em que a difusão do audiovisual assume significativas proporções com leitores ainda pouco experientes. As diretrizes para uma política pública voltada à leitura e ao livro centrada nas bibliotecas e formação de mediadores são contempladas no PNLL.

O PNLL e seu desdobramento nos Planos Estaduais e Planos Municipais de Livro e Leitura estão sendo implantados em várias cidades do país desde 2009. A leitura e a escrita devem ser consideradas base em processos de formulação e implantação de políticas públicas de educação e cultura dos governos em todos os seus níveis e modalidades de ensino e de administração, e, junto com o tema das línguas, perpassá-las estruturalmente, tal como proposto no Plano Nacional de Cultura (PNC), elaborado pelo Ministério da Cultura. A consolidação de políticas e programas de fomento à leitura deve ser pensada a curto, médio e longo prazos, com ênfase no caráter permanente. Nesse processo, o fomento e a elaboração de Planos Estaduais e Municipais do Livro e Leitura articulados com o Plano Nacional se tornam fundamentais, mas a morosidade nas decisões e a falta de orçamento garantido compromete o programa.

O Brasil alcançou com PNLL um patamar político e conceitual que é imprescindível para se consolidar uma Política de Estado para o setor em consenso entre governo e sociedade. A obtenção deste consenso foi o que mais projetou o PNLL para os países ibero-americanos, tornando-se referência para muitos dos planos de leitura que também se desenvolvem nos países do continente americano e no mundo ibérico. A ligação conceitual e prática da ação do Estado com a sociedade e a indissociabilidade entre cultura e a educação na formação de leitores são pontos referenciais que o PNLL do Brasil possui e foram debatidos e assimilados como necessidade da política pública de leitura em inúmeros foros 
internacionais, particularmente aqueles organizados pelo CERLAC/Unesco (Red de Dirigentes de Planes de Lectura) e pela OEI (Comitê de expertos em lectura y biblioteca).

O debate amplo iniciou-se em 2005 com a criação da Cátedra Unesco de Leitura, Ano Ibero-americano da Leitura. Os resultados colhidos nas 24 Assembleias Setoriais do Livro, Leitura e Literatura, que precederam a Conferência Nacional de Cultura em março de 2010 mostraram um interesse muito ampliado, com prêmios nacionais, envolvendo editoras e o estado, como no VivaLeitura.

Entre as muitas possibilidades de textos adotados no trabalho com a leitura, a literatura merece atenção especial no contexto do Plano, dada a enorme contribuição que pode trazer para uma formação vertical do leitor e minimizar em parte, a grave situação da falta de compreensão dos textos escritos e a premência de sua superação. Para o MinC, as palavras livro, leitura e literatura referem-se, respectivamente, às três dimensões de nossas políticas culturais - a econômica, a do direito da cidadania e a do valor simbólico. Essas dimensões precisam ser desenvolvidas articuladamente.

O modelo atual de formação de mediadores está sendo desenvolvido em parceria com a Cátedra Unesco de Leitura PUC-Rio, que selecionou e está formando 3.142 agentes em 15 estados brasileiros. Para Cátedra:

A leitura é compreendida como interação entre texto e leitor, ambos forjados no amplo circuito de significações, mídias e culturas da contemporaneidade. Deste modo, qualquer projeto de formação de leitores precisa considerar:

a) as linguagens do mundo, os repertórios individuais e acervos coletivos;

b) o ambiente cultural em que se dá a leitura (modos de leitura);

c) as distinções e aproximações existentes entre a história de vida e a história do leitor;

d) as diversidades de narrativas e de técnicas de escrita (verbal e não verbal); e, sobretudo;

e) recepção e contexto (o momento único da interação). ${ }^{5}$

O Plano valoriza particularmente três fatores qualitativos e dois quantitativos identificados pela Unesco como necessários para a existência expressiva de leitores em um país, como se identifica abaixo:

\footnotetext{
${ }^{5}$ http://www.catedra.puc-rio.br/index.asp Acesso realizado em 03/12/2012.
} 
Os fatores qualitativos são:

a) O livro deve ocupar destaque no imaginário nacional, sendo dotado de forte poder simbólico e valorizado por amplas faixas da população;

b) Devem existir famílias leitoras, cujos integrantes se interessem vivamente pelos livros e compartilhem práticas de leitura, de modo que as velhas e novas gerações se influenciem mutuamente e construam representações afetivas em torno da leitura; e

c) Deve haver escolas que saibam formar leitores, valendo-se de mediadores bem formados (professores, bibliotecários, mediadores de leitura) e de múltiplas estratégias e recursos para alcançar essa finalidade.

Os fatores quantitativos são:

d) Deve ser garantido o acesso ao livro, com a disponibilidade de um número suficiente de bibliotecas e livrarias, entre outros aspectos;

e) O preço do livro deve ser acessível a grandes contingentes de potenciais leitores.

O PNLL reúne projetos, programas e ações de ministérios, instituições públicas dedicadas à educação e à cultura, empresas estatais de todos os níveis de governo e ainda, empresas e entidades privadas como as organizações não governamentais (ONGs) que apoiam a educação e, gradativamente, vão aderindo ao plano que se estruturou em quatro eixos, sintetizados da proposta inicial do Proler:

- Democratização do acesso

- Fomento à leitura e à formação de mediadores

- Valorização da leitura e comunicação

- Desenvolvimento da economia do livro.

No âmbito federal, a Diretoria de Livro, Leitura e Literatura, vinculada à Secretaria de Articulação Institucional, é o órgão do Ministério da Cultura responsável por formular políticas, programas, projetos e ações de acesso, difusão, produção e fruição ao livro e à leitura. Cabe ainda à Diretoria articular com a Fundação Biblioteca Nacional/Sistema Nacional de Bibliotecas Públicas os programas de implantação e modernização de bibliotecas públicas municipais; integrar as políticas do Ministério com o Plano Nacional do Livro e da Leitura; articular e mobilizar os entes federados e a sociedade civil em torno de leis e de

\footnotetext{
${ }^{6}$ http://www.pnll.gov.br/ Acesso realizado em 15 out. 2012.
} 
planos estaduais e municipais de livro e leitura; coordenar, integrar, monitorar e avaliar as ações de livro e leitura do Programa Mais Cultura.

Cabe à Fundação Biblioteca Nacional promover a difusão do livro, incentivando a criação literária nacional, no país e no exterior; atuar como centro referencial de informações bibliográficas; adquirir, preservar e difundir os registros da memória bibliográfica e documental nacional; coordenar, orientar e apoiar o Proler; coordenar o Sistema Nacional de Bibliotecas Públicas; subsidiar a formulação de políticas e diretrizes voltadas para a produção e o amplo acesso ao livro, dentre outras atribuições.

No âmbito do Ministério da Educação, cabe ao Fundo Nacional do Desenvolvimento Educacional (FNDE), em parceria com a Secretaria de Educação Básica (SEB), Secretaria de Educação Continuada, Alfabetização e Diversidade (Secad) e Secretaria de Educação Especial (Seesp) executar programas do livro e apoiar programas de leitura, por meio de convênios.

Cabe ainda dar continuidade às diversas políticas e ações que vem implementando nos últimos anos em diferentes frentes (acesso à produção científica, didática e artístico-cultural; fomento a projetos de mediação de leitura; produção de material científico, didático e artístico-cultural; pesquisa e avaliação sobre leitura e escrita, formação de mediadores de leitura; apoio à produção e distribuição de material literário para neoleitores), por meio de Instituições e Programas como o Instituto Nacional de Estudos e Pesquisas Educacionais Anísio Teixeira (INEP); Centro de Informação e Biblioteca em Educação (CIBEC); TV Escola; Portal de Periódicos da Capes; Programa Nacional do Livro Didático (PNLD); Programa Nacional da Biblioteca Escolar (PNBE); Programa Nacional do Livro Didático para EJA (PNLDEJA); Concurso Literatura para Todos; Núcleo de Atividades do Projeto Rondon (Napro); Sistema Nacional de Avaliação da Educação Superior (Sinaes); Sistema Nacional de Avaliação da Educação Básica (SAEB).

"Este Plano procura contemplar, de forma dialética, um processo de dupla face: tanto aquele moldado pelas questões que envolvem a leitura, quanto o que se configura pelos problemas relativos à cadeia produtiva do livro, buscando evitar polarizações que a tradição tem revelado inócua, no que diz respeito aos papéis a serem cumpridos pelo Estado e à dinâmica específica do mercado. 
São necessários mecanismos contínuos de avaliação das metas, dos programas e das ações desenvolvidas para verificar o alcance das iniciativas e os resultados obtidos, permitindo ajustes, e atualizações no processo." (PNLL Edição atualizada em 2010).

Contudo estamos longe, dentro e fora dos ministérios de uma articulação desejada e necessária às ações oficiais e não-governamentais. 


\section{2 \\ Leitura Literária}

O verbo ler não suporta imperativo.

Daniel Pennac

\section{1 \\ A escola}

Quando mandamos as crianças para a escola, costumamos pensar que lá elas obterão todos os conhecimentos necessários para a sua formação. No entanto, muitas vezes nos esquecemos de considerar que as crianças já levam consigo um acervo próprio. É um acervo de narrativas e saberes que ouviram e aprenderam com seus familiares, sua comunidade, e que não podemos desprezar. Reconhecer a importância de suas histórias, e saberes prévios, proporcionará uma abordagem mais próxima e menos artificial do que é, de fato, conhecimento.

Numa perspectiva da História Cultural abordada por Roger Chartier, verifica-se que a escola é uma comunidade em que todos são igualados na impotência perante a autoridade do professor. As relações da escola com a vida parecem contraditórias, pois ela nega o social para introduzir em seu lugar o normativo. A escola usa a literatura como instrumento pedagógico, tendendo para o ensino moralizante e propedêutico, ao invés de formar leitores numa perspectiva estética. (Soares, 2001)

Uma escola encarregada de dar suporte ao funcionamento do Estado e da sociedade, comprometida com a ideologia reinante de poder, colocando a criança como a imagem da impotência e incapacidade, tendo que ser domesticada, faz uso do livro literário em sala de aula não como obra de ficção, mas como instrumento para a "formação" do indivíduo. No entanto, a literatura não se confunde com uma missão pedagógica de formação, embora faça parte, sim, da constituição dos indivíduos. Ela está voltada para a cultura e, por meio de sua linguagem 
simbólica, propicia os elementos para uma emancipação pessoal, o que é a finalidade implícita do próprio saber.

A ideologia burguesa vincula a literatura ao hábito e ao gosto da leitura, como procedimento para obtenção de informações e aquisição de normas, em que o ler é sinal de ilustração e civilidade, expressão do nível cultural burguês. O uso da literatura como matéria educativa tem longa história. (Lajolo, 1982) A literatura passa a ser utilitária: tanto serve para ensinar a ler e escrever quanto para formar culturalmente o indivíduo. No Ensino Fundamental, a literatura tem a função de sustentar a formação do leitor; no Ensino Médio, integrar esse leitor à cultura literária brasileira de forma muito ampla, mas isso não é o que acontece. No Fundamental, o aluno começa interessado "nas histórias", mas não domina o discurso, a linguagem, gramática. Vai perdendo o encanto, e passa a associar o ato de ler a algo complexo ao sentir-se sempre mais desqualificado.

No Ensino Médio, a literatura já está convertida em períodos, características, estilos, que não condiz com o literário propriamente dito, senão de uma perspectiva analítica, histórica, que estaria contemplada melhor e mais criticamente no curso de Letras. Nesse caso, o verdadeiro interesse de aprender a pensar, correlacionar situações, expressões, ideologias, ações, desaparece para dar lugar ao conhecimento mecânico, logo, descartável.

Assim, no primeiro momento, a literatura deveria ser tratada pela temática e pela linguagem dos textos compatíveis com o interesse da criança, do professor e da escola, de modo geral divertidos, contemporâneos e curtos, sem preenchimento de fichas de leitura. As fichas pressupõem respostas préestabelecidas que os alunos devem "acertar". A liberdade de interação passa a ser ignorada em prol de boas notas e suposto êxito escolar. A possibilidade do prazer de ler se esvai, e a tendência é que se considere a literatura mais uma disciplina com que se preocupar somente na hora de realizar provas, vestibulares e concursos.

Também no segundo segmento, como foi dito, o prazer de ler vira o ensino de literatura e limita-se à produção brasileira com uma cronologia literária, em uma sucessão de estilos de época, cânones e dados biográficos dos autores, em perspectiva historiográfica. Os textos literários, quando aparecem, são fragmentos e servem prioritariamente para comprovar as características dos períodos literários estudados no livro didático. Raras são as oportunidades de leitura de um texto 
integral. Assim não se diferencia muito do resultado obtido no Ensino Fundamental: geralmente o estudo fica concentrado ao resumo, ao tema abordado e às características do estilo. Não é observada sua composição, as informações contextuais que poderiam ajudar a construir leituras diversas. A crítica, a teoria ou a história literária entram de forma autoritária e sem conexão com a vida do aluno.

Soares (2001), no ensaio A Escolarização da Literatura Infantil e Juvenil, considera a escolarização da literatura um fato e afirma que se deve criticar a forma inadequada como a literatura é tratada. A didatização e a pedagogização deturpam, falseiam e distorcem o texto literário. É de responsabilidade da escola proporcionar a experiência literária sem transformá-la em um simulacro de si mesma que mais nega do que confirma seu poder de humanização.(Cosson, 2006, p.23)

Literatura não é para ser disfarce de ensinamentos. Livros de literatura diferem de livros didáticos exatamente porque trazem personagens paradoxais como, por exemplo, uma boneca que fala, um menino que tem um tapete voador, uma fada que tem o pó mágico de pirlimpimpim, um defunto que conta sua história, um personagem que vive as peripécias das histórias de cavalaria. A riqueza da literatura reside no texto inventivo, não linear, de conteúdo complexo, pluralidade de interpretações possíveis e vários níveis de leitura. Esses planos de ficção não se propõem como fuga ou nonsense: eles são ensaios do que poderiam acontecer no plano imaginário.

O reconhecimento da singularidade da literatura na formação de qualquer leitor proporciona ao aluno localizar-se em um universo cultural. Práticas de leitura são concebidas como práticas culturais, portanto devem ser vivenciadas no dia a dia, e não ensinadas como matéria de escola. A leitura do texto literário, em seus diferentes gêneros, contribui para a formação de um leitor crítico, capaz de articular o mundo das palavras com seu eu mais profundo e a comunidade onde ele se insere. Cabe à escola ensinar os mecanismos de interpretação, como lidar com textos literários de forma que a troca de sentidos não esteja somente entre escritor e leitor, mas também com a sociedade onde ambos estão localizados, pois os sentidos são resultado de compartilhamento de visões do mundo entre os homens no tempo e espaço. (Cosson, 2006, p. 27)

A literatura não só nos permite saber da vida por meio da experiência do outro, como também vivenciar a experiência do outro. $\mathrm{Na}$ arqueologia poética de 
Aristóteles, experimentar a catarse provocada por uma cena possibilitaria ao espectador atingir um estado interno "alterado", o qual mostraria sua própria natureza e condição humana. $\mathrm{O}$ deslocamento provocado pela catarse tornaria o mundo mais compreensível, transformando sua materialidade em palavras - de cores, odores, sabores e formas intensamente humanas.

O conceito de catarse de Aristóteles, porém, possui diversas e controvertidas interpretações por ser de difícil tradução. Por exemplo, uma interpretação coloca o centro da catarse na mente do espectador, gerando uma estética de base subjetivista, cuja meta é o estudo da recepção da arte. Outro tipo aborda a catarse como algo que acontece na cena e, por isso, atinge o espectador. A relação com o livro pode ser então, amorosa, sagrada, ou indiferente quando o texto não mobiliza a vivência do leitor/espectador.

Todavia, a leitura como formadora só se dá quando se concretiza como experiência, quando as palavras e as imagens recriam a experiência de mundo. Não é possível aceitar que a simples atividade de leitura seja considerada a atividade de leitura literária: é preciso promover o letramento literário.

Rildo Cosson trata o letramento literário como uma prática social e de responsabilidade da escola. Diz que os livros, como os fatos, jamais falam por si mesmos.

O que os fazem falar são os mecanismos de interpretação que usamos, e grande parte deles são aprendidos na escola.(...) No ambiente escolar, a literatura é um lócus de conhecimento e, para que funcione como tal, convém ser explorada de maneira adequada. A escola precisa ensinar o aluno a fazer essa exploração. (Cosson, 2006, p.27)

O letramento literário seria uma forma de, rompendo o círculo da reprodução ou da permissividade, exercida sem o abandono do prazer, mas com o compromisso de conhecimento, realizar fundamentalmente para a formação ${ }^{7}$ do aluno. É uma prática social de responsabilidade da escola e diferente do que se considera a escolarização da literatura. A literatura nos diz o que somos e nos incentiva a desejar e a expressar o mundo por nós mesmos. E isso se dá porque a literatura é uma experiência a ser realizada. É mais que um conhecimento a ser

\footnotetext{
${ }^{7}$ A burguesia ascendente dos séculos XVIII e XIX , patrocinadora da expansão e aperfeiçoamento do sistema escolar, necessita formatar/colocar na forma crianças. No século XXI, formação das crianças/leitores passa a ser - ajudar a ganhar forma.
} 
reelaborado, é a incorporação do outro em mim, sem renúncia da minha própria identidade. No exercício da literatura, podemos ser outros, podemos viver como os outros, podemos romper os limites do tempo e do espaço de nossa experiência e, ainda assim, sermos nós mesmos.

O processo de formar e adquirir conhecimento, reconhecido na teoria do conhecimento, passa pela sensibilidade de cada um, conferindo um entendimento peculiar, que ao olhar o mundo vem recheado de memórias e experiências, afetando o que conhece.

O conhecimento, malgrado os esforços de objetividade, está "contaminado" pelo recorte ou pela grade que a sensibilidade e o entendimento de cada um the conferem. (...) A razão não comanda sozinha a pessoa e a consciência não é a senhora do conhecimento. (Yunes, 2009, p.31)

Os sujeitos, porque não estão isolados, formulam o conhecimento expressando-o em diversas linguagens. O discurso proferido por cada um é permeado pela intersubjetividade, o que depreendemos no intercruzamento de vozes. A visão da realidade de mundo passa pela intersubjetividade que constitui cada pessoa e prevalece como condição constitutiva da subjetividade de cada um.

As escolhas que fazemos se revelam nas interpretações que conferimos ao mundo e aos textos a partir de nossa singularidade. A formação de cada um como interlocutor do mundo se dá assentada sobre os acervos, repertórios que elegemos com a capacidade de pensar singularmente. A interpretação da obra é produzida por um leitor que não repete o que ouve, mas se coloca criticamente e se faz autor. Ler é, pois, um ato de primeira instância no esboço da consciência de si mesmo e do outro e sua inscrição no mundo se dá como uma escrita de vida. (Yunes, 2009, p.35)

Fica difícil descobrir prazer na leitura em meio à grave crise social em que estamos inseridos há décadas, com uma população empobrecida, sem perspectivas de futuro, e com educação inócua. Uma saída interessante para a retomada do papel cultural da literatura na formação da cidadania tem sido realizada por meio de planos, programas e projetos de leitura, uma série de práticas pedagógicas desescolarizadas, ou seja, com propostas renovadas. A professora Eliana Yunes, que criou o Programa Nacional de Incentivo à Leitura (Proler) no Brasil, aponta para a importância da memória afetiva no contato com as narrativas. Essa relação 
é muitas vezes frustrada pela forma como somos introduzidos aos textos literários na escola: Essas memórias de felicidade clandestina com a palavra, pronto desaparecem atravessando o umbral da escola onde aprendemos a ler e a escrever, como ensina a tradição. (Yunes, 2009, p.70)

A tendência a se escolarizar a leitura se soma, hoje, à forte presença das novas tecnologias no cotidiano. Como professora de Língua Portuguesa no Ensino Fundamental e Médio na rede pública e privada, durante um longo período de minha vida profissional, eu sentia o distanciamento do interesse dos alunos pela leitura/literatura ensinada nos moldes que vivi e em que fui formada pela universidade. Após tanta exposição à televisão, internet e aos celulares que não mais funcionam como um simples telefone, as crianças e adolescentes são positivamente outros. A contínua exposição à linguagem de imagens e a necessidade de uma rápida resposta conectada a uma imensa rede de comunicação colocam o aluno como um ser multimídia, um emissor/receptor totalmente diferente daquele que se comunicava por telégrafo e telefone em meados do século XX.

A rapidez atordoante do mundo em que vivemos leva-nos à necessidade de saber lidar com todas as linguagens, verbais e não verbais, do cinema, televisão, rádio, fotografia, pintura, internet, jornais, revistas e livros. Fazemos parte de uma sociedade cada vez mais visual, que necessita de uma escola com professores e educadores voltados para a polissemia da comunicação, ou seja, onde muitos sentidos cabem nos problemas e nas respostas. A leitura das imagens, assim como dos textos, depende muito da bagagem cultural do professor/mediador e do leitor. Em outras palavras, temos um sistema escolar vigente que não dá mais conta de responder à demanda do mundo de hoje.

Para analisar melhor as práticas pedagógicas, precisei mergulhar na reflexão teórica sobre a estética da recepção. Eu me perguntava como essas práticas foram se constituindo e em quais concepções de leitura se sustentam. Minha intenção é trazer a teoria não como explicação do real, mas na ótica apresentada por Brandão (2002, p.71), como hipótese. A tese defendida por Jauss desde 1967 pressupõe a reflexão estética como base de toda a recepção, com postura racional e crítica. $\mathrm{O}$ diálogo entre leitor e texto não seria apenas fonte de prazer, mas também uma atividade imaginante, experimentadora e doadora de significação: (...) a atitude estética que o objeto distanciado não seja contemplado 
desinteressadamente, mas que seja conduzido pelo fruidor à semelhança do que se passa no mundo imaginário, em que entramos como coparticipantes - como objeto imaginário. (Jauss, 1979, p.75)

O prazer estético se realizaria na oscilação entre a contemplação desinteressada e a participação experimentadora que libertaria o leitor de sua existência cotidiana. Para que o leitor/espectador se liberasse para o exercício da leitura do objeto representado, e a experiência subjetiva se transformasse em intersubjetiva, pela anuência ao juízo exigido pela obra, seria necessário o distanciamento e a apreciação reflexiva. Assim, a verdade social da arte não dependeria apenas da mediação do prazer estético. A função comunicativa da experiência estética não seria necessariamente mediada pela função catártica, com base nos afetos.

Outrora, o prazer se justificava, como um modo de domínio do mundo e de autoconhecimento:

(...) o prazer da arte não passa de uma reação burguesa à espiritualização da arte sendo desta forma o pressuposto para a indústria cultural da atualidade, que no circuito fechado das necessidades dirigidas e do ersatz estético, serve aos interesses camuflados do poder. (Jauss, 1979, p.71)

O prazer estético era, até a década de 1980, ou seja, até bem pouco tempo atrás, um privilégio da cultura burguesa. A atitude teórica e estética realizou-se sob a necessidade de sua justificação, ante as instâncias da filosofia e da religião: A reflexão moderna sobre conduta de prazer, que era capaz de liberar a produção e a recepção da arte, permaneceu por muito tempo subordinada à argumentação retórica e moralista. (Jauss, 1979, p. 64)

Quando o leitor faz a sua atividade estética ser acompanhada pela reflexão sobre seu próprio devir no processo de uma formação estética da identidade, $a$ importância do texto não advém da autoridade de seu autor, não importa como ela se legitime, mas sim da confrontação com nossa biografia. O autor somos nós, pois cada um é o autor de sua biografia. (Jauss, 1979, p.82)

Hoje, para muitos, a experiência estética só é vista como genuína quando se priva de todo prazer e se eleva ao nível da reflexão estética. Fico me perguntando se a questão da ausência do prazer de ler na escola, no que concerne às expressões artísticas, especialmente à literatura, estaria relacionada ao 
privilégio da reflexão estética. Esta, poucos podem conseguir na fase inicial de formação. Assim, o prazer acaba recalcado, quando tratamos de trabalho escolar, e depois se perde efetivamente o passo para uma transformação das relações com a linguagem.

\section{2 \\ Escola, espaço de troca cultural}

A escola, sobretudo a pública, tem sido sucateada pelo desamparo dos professores, pela indiferença da sociedade, pela omissão das autoridades que maqueiam com uma assistência pífia, a complexa engrenagem do sistema educativo.

Para ampliar o atendimento à crescente população em idade escolar, prédios e profissionais foram submetidos a uma desvalorização visível e gradual que agora atinge os índices brasileiros no IDH e no PISA.

Confinada à esmola de uma gratificação esporádica, isolada dos bens culturais que a justificariam, a escola deixou de ser espaço de vida cultural explícita, de socialização, para ser espaço de violência e expropriação de valores.

Educar na escola é unir talento de cada um e suas vivências, do rico acervo da vida social; este lugar de encontro e trocas, no contexto que examinamos, se revela um apêndice do fracasso escolar, uma bengala para caminhar além da inércia. Denúncia e socorro, o Segundo Turno Cultural é uma exigência para tentar salvar tanto crianças, como o próprio sistema.

Contudo, a escola permanece sendo a esperança de uma socialização humana, humanizada, a chance de apropriação da cultura e da arte que sensibilizam e alimentam delicadeza, gentileza, solidariedade, ética e por fim justiça na vida comum.

Recuperar esta condição para as escolas já estigmatizadas é o empenho de quem seriamente está comprometido com as mudanças possíveis.

A proposta do projeto em funcionamento desde 2009 no município do Rio de Janeiro, Segundo Turno Cultural, tem por meta proporcionar experiências culturais novas para os alunos da rede pública na escola. Os alunos se inscrevem 
na atividade que lhes interessa e passam a vivenciar, nas oficinas oferecidas, momentos lúdicos que os auxiliarão a construir sua identidade cultural mais ampla, inclusiva. Nas oficinas de leitura e literatura que pesquiso, a leitura é uma prática criativa, que se propõe a garantir a presença do texto literário como componente da formação da identidade cultural dos alunos.

Sob os textos oferecidos, desliza o olhar curioso dos alunos que procuram articular seus significantes a significados próprios. Apropriando-se deles, o leitor interpreta de um lugar, universo do discurso que é seu, para abrir uma perspectiva nova que lhe faça sentido. Daí que a qualidade desafiadora dos textos deverá ser considerada com ênfase.

\begin{abstract}
Na recepção, a abertura e a disponibilidade de si para interagir com uma obra nascem da subjetividade construída pouco a pouco pelas interações com outros sujeitos, outros repertórios, outros acervos. Há que se tenha aprendido escutar e falar para ler e escrever. A recepção de um texto, quer ele se apresente mais fechado em seus sentidos (normas, doutrinas), quer se apresente mais aberto (palavra sagrada, poética), carece de um leitor curioso, estimulado, para se colocar diante da palavra alheia e descobrir a própria. (Yunes, 2009, p.41)
\end{abstract}

Semanalmente, os encontros promovidos pelas oficinas de leitura são resultado do encontro de artistas que transitam entre várias linguagens, e que contam, em suas trajetórias individuais, com distintas vivências; apresentam-se para ou com o público infantojuvenil, entre contação de histórias, cursos e espetáculos. As oficinas, Literatura em Rede, Encontros de Leitura e Ateliê de Histórias, desenvolvem um trabalho artístico de integração de linguagens que cria circunstâncias novas para uma aproximação com o livro, aprimora a sensibilidade e estimula a produção de sentido. Além de favorecer a sociabilização, as atividades apresentadas exploram múltiplos potenciais, valorizando a autoestima e contribuindo para a redução da violência. Em suma, viabilizam uma experiência com o texto artístico inserido num mundo plural cujas fronteiras culturais das narrativas são rompidas e o invento e a criatividade têm espaço.

Como as oficinas não cobram presença, é frequente termos alunos diferentes a cada encontro. Para inseri-los no contexto orgânico da oficina, um aluno, presente na semana anterior, conta a história trabalhada e, ao mesmo tempo, apropria-se dela e a reconta do seu jeito; muitas vezes outros do grupo interrompem, corrigindo, detalhando algo que sintam como precioso para o 
entendimento da narrativa. Fica evidente, então, a apropriação do que foi contado, mas a versão narrada pelos alunos não é mais aquela do autor, nem a do contador, do professor ou mediador. Mas, a ausência do aluno é de certa forma, uma perda para o grupo, pois há muitos recuos para contemplar a todos do grupo.

\section{3 Fruição mediadora e suas conduções}

O mediador faz as apresentações, aproxima os que estão distantes sem poder, por conta própria, dar-se a conhecer. Atua como o personagem adulto no famoso miniconto de $\underline{\text { O livro dos abraços, }}$, de Eduardo Galeano:

"Diego não conhecia o mar. O pai, Santiago Kovadloff, o levou para que descobrisse. Viajaram para o sul. O mar estava mais além das altas dunas, esperando. Quando o menino e seu pai alcançaram por fim aqueles picos de areia, depois de muito caminhar, o mar estava lá diante de seus olhos. E foi tal a imensidão do mar e tanto seu fulgor, que o menino ficou mudo pela formosura. E por fim, quando conseguiu falar, tremendo, balbuciando, pediu ao pai:

- Ajuda-me a ver!"

Eis o papel do mediador. Ao professor cabe criar as condições para que o encontro do aluno com a literatura seja uma busca de sentido, para o próprio aluno e para a sociedade em que todos estão inseridos. O mediador mais importante é ou deveria ser, o professor, figura fundamental na história escolar de cada aluno. A leitura é ferramenta essencial para a prática de seu ofício, por isso ele precisa revelar-se um leitor apaixonado e tornar-se uma forte referência para seus jovens parceiros de aventura, a aventura de ler. Cabe a ele o papel de despertar e desenvolver no aluno o gosto pela leitura a partir de uma aproximação afetiva e significativa com as histórias, nos livros, na tela, no palco. No entanto, para que haja êxito na formação do leitor, o professor/mediador precisa efetuar uma leitura estimulante, reflexiva, diversificada, crítica, propiciando aos alunos descobrirem a leitura para viver melhor, entendendo-se no mundo. É como descobrir o mar, para Diego. É como responder ao menino, silenciosamente, segundo Kovadloff.

Em suma, se quisermos formar leitores capazes de experienciar a força humanizadora da literatura, não basta apenas ler. Até porque, ao contrário do que acreditam os defensores da simples leitura, não existe tal coisa. A leitura 
"simples" é apenas a forma mais automática de leitura, porque esconde sob a aparência de decodificação todas as implicações contidas no ato de ler e de ser letrado. É justamente para ir além da "simples leitura" que o letramento literário é fundamental no processo educativo. Ler além das linhas, as entrelinhas; o dito e o implícito, a versão e a alusão.

O ensino da literatura deve ter como foco a experiência do literário. As práticas de sala de aula precisam contemplar o processo de letramento literário e não apenas a mera leitura das obras. Cabe ao professor levar o aluno para mais além da compreensão do texto, ultrapassar o simples consumo de textos literários, construir uma comunidade de leitores.

Regina Zilberman, encarregada de escrever o tomo sobre literatura infantil da coleção Como e por que LER, aponta a sistemática adotada por Monteiro Lobato de tomar crianças como personagens principais inseridos em aventuras desafiadoras convivendo "com heróis tradicionais, que habitam os mitos, as lendas, os contos folclóricos, as epopeias, em outras palavras, todas as narrativas ouvidas desde pequenos e reencontradas não apenas na literatura, mas em outros meios de comunicação, sobretudo os de massa, como o cinema, a TV, a história em quadrinhos, os jogos de computador." (Zilberman, 2005, p.23) Seria uma estratégia que ofereceria um acervo, para ajudar a construir uma comunidade de leitores dentro de uma ambiência cultural na qual eles poderão se mover e construir o mundo e a eles mesmos.

Para tanto, é necessário que o ensino de literatura efetive um movimento contínuo de leitura, partindo do conhecido para o desconhecido, do simples para o complexo, do semelhante para o diferente, com o objetivo de ampliar e consolidar um repertório cultural do aluno.

A escola precisa estar consciente do seu papel de mediador, sendo ela a principal responsável pela transmissão da cultura desta civilização bimilenar. Já que a sociedade e nela a família anda dispersa com o trabalho e o lucro. O espaço escolar é diferente de outros espaços da cidade, justamente porque a escola tem um papel formativo que deve prevalecer. As leituras escolares ampliam o acervo pessoal de vivência do aluno, quando disponibilizam uma biblioteca com materiais de qualidade e que contemplem a diversidade de gêneros e temas.

É comum à grande parte do pensamento contemporâneo estender o que seja leitura a qualquer fenômeno comunicativo. Poderíamos dizer que a reflexão 
sobre a experiência de leitura não se relaciona somente com o que acontece na mediação, no texto ou com o leitor, mas se amplia a qualquer processo de transmissão de sentido em suas mais diversas expressões culturais.

Recorro a alguns teóricos para auxiliar minhas reflexões sobre a questão da leitura literária. Jorge Larrosa, filósofo da educação e especialista em leitura, assim se expressa em Linguagem e Educação depois de Babel:

(...) A condição humana da pluralidade, poderíamos acrescentar, deriva do fato de que o que há são muitos homens, muitas histórias, muitos mundos e muitas realidades. Isso é óbvio, ainda que nunca é demais lembrá-lo contra todos aqueles que querem meter-nos em sua realidade com pretensão de ser $a$ realidade, em seu mundo com pretensões de ser $o$ mundo, em sua linguagem com pretensões de ser $a$ linguagem, em sua razão com pretensões de ser $a$ razão, em sua história com pretensões de ser $a$ história ou em sua humanidade com pretensões de ser $a$ humanidade. (Larrosa, 2004, p.69)

As estruturas muitas vezes rígidas das práticas escolares acabam por afastar o aluno da literatura, por se colocarem como $a$ realidade, $o$ mundo possível, $a$ linguagem correta, e pretenderem ser $a$ razão perfeita, $a$ "dona" da história, enfim apresentando-se como via única de possibilidade de leitura. Não existe tal coisa como $a$ linguagem nem tampouco coisa tal como $a$ leitura não problematizável: não existe uma única leitura. Leitura significa multiplicidade e singularidade; é um invento pedagógico querer alcançar uma ou $a$ resposta.

Um conceito de leitura mais amplo que compreenda diversos sistemas simbólicos com a finalidade de integrar o ser humano ao mundo em que vive, eis o objetivo das oficinas pesquisadas. Conhecer parte da herança humana e socializá-la através dos contos, lendas, poesias que formam a memória coletiva, patrimônio da humanidade que também funciona como importante trilha para compreender a vida interior, eis um forte objetivo que permeia as oficinas de leitura que observei de maio a dezembro de 2012.

Pensar a leitura é próprio da mediação, da diferença mediada tratada pela hermenêutica contemporânea, uma busca pelo diálogo, da leitura como prática de linguagem, de comunicação, de construção do comum e do singular, tanto no espaço como no tempo. Considerem-se, também, as enormes dificuldades de cada um e dos sujeitos em seu conviver. Pensemos na figura do mediador que precisa ser antes, leitor, das situações, dos contextos e das narrativas. 
No interior dessa lógica, dessa dialógica, poder-se-ia situar, sem dúvida, o sujeito da compreensão, que se constitui, em certo sentido, permeando o político, o cultural, o social, o pedagógico e o estético. E que também permeia as teorias de leitura implícitas a todos esses domínios. O sujeito da compreensão se crê capaz de converter o passado em seu próprio passado, de apropriar-se do passado compreendendo-o, fazendo-o seu. E também se vê capaz de mediar as diferenças: entre os indivíduos, entre as culturas. A compreensão de uma forma de mediação está em um estender pontes no espaço e no tempo, entre sujeitos, textos, vozes, situações, pois o que quer, ao compreender, é converter o passado em presente, o distante em próximo, o estranho em familiar, o fora no dentro, o que não é seu em seu. Por isso, tudo participa da formação de sua identidade em expansão. Aquilo que compreende, em princípio, o faz melhor: mais culto, mais sensível e mais maduro, evitando o sentimento de ignorância, de auto-rejeição. Assim, passa a compreender mais, baseando-se em seu repertório, em sua sensibilidade, em sua inteligência, em sua maturidade. O sujeito da compreensão, portanto, é o leitor etnocêntrico, sem negar a diferença, mas se apropriando da diferença, traduzindoa na sua própria linguagem e ao mesmo tempo, é o primeiro passo para reconhecer a diferença, da qual pode divergir e rejeitar.

Como exemplo de uma iniciativa em que a mediação não foi considerada, cito o programa Literatura em minha casa, promovido pelo Governo Federal em 2001 e 2002, que distribuiu livros aos alunos das $4^{\mathrm{a}}$ e $5^{\mathrm{a}}$ séries do Ensino Fundamental. Eles levaram para casa os livros com intuito de proporcionar leitura também à família. Sabe-se, no entanto, que além da falha na distribuição das obras (muitas coleções ficaram na escola) e apesar de haver um manual que as acompanhava, não se conseguiu um bom resultado de leitura, no que tange ao leitor/aluno e à família, assim como ao mediador/professor que não recebeu capacitação: muitos nem chegaram a ler o material escolhido pelo MEC. Sem agentes de leitura preparados para estender a leitura para fora da escola, ou seja, para as famílias, o projeto não cumpriu sua meta.

Talvez esse seja um excelente exemplo da urgência e do valor que tem uma boa experimentação na formação de mediadores de leitura para estimular novos leitores: não basta fornecer livros a mancheia", como disse Castro Alves. Uma medida de leitura dessa envergadura teria tido outro resultado com o envolvimento da comunidade escolar, associada a um trabalho de mediação. Por 
isso, nos dias atuais, o programa do Ministério da Cultura, antes de levar livros pelo país afora, investe na formação de agentes de leitura, reconhecendo a importância da mediação.

O programa de formação de agentes de leitura proposto pelo Ministério da Cultura, atualmente em curso, tem a coordenação pedagógica da Cátedra Unesco de Leitura, PUC-Rio. Ele visa preparar até 3 mil agentes de leitura na primeira etapa, que vão atender a domicílio integrantes do Bolsa Família. Os jovens agentes, entre 18 e 29 anos, devem visitar comunidades de baixo Índice de Desenvolvimento Humano (IDH), levando livros, e incentivar a leitura. Cada agente recebe uma bolsa de R $\$ 350$ por mês e atua na comunidade, visitando regularmente 25 famílias. O programa é uma das estratégias do Plano Nacional do Livro e Leitura (PNLL) visando à democratização do acesso ao livro e formação leitora. O programa segue um modelo implementado em menor escala em 2005 pelo governo do Ceará, baseado na ideia do educador Fabiano dos Santos Piúba, hoje diretor da área de Leitura no CERLALC Unesco, de que o agente tem que ser um leitor para despertar o gosto pela leitura nas pessoas ${ }^{8}$. Os três ambientes fundamentais para leitura, segundo Piúba seria: as famílias, as bibliotecas e as escolas.

O ambiente de atuação dos agentes em sua atividade fim junto às comunidades compreende bibliotecas públicas municipais, escolas, fábricas, empresas, associações, comunidades e os lares cujos moradores dispõem participar do projeto.

Cada agente cadastra um grupo de trinta famílias de sua comunidade, onde desenvolve atividades de formação leitora como rodas de leituras, cirandas de livros, leituras compartilhadas, empréstimos de livros, contação de histórias, saraus artísticos, performances literárias, registros de contos.

\footnotetext{
${ }^{8}$ http://www.catedra.pucrio.br/portal/p/?/43/455/comunicacao/aconteceu_na_catedra/ii_encontro_de_formadores_do_projet o_agentes_de_leitura. Acesso em: 30 jan 2013
} 


\title{
2.4 \\ O Leitor
}

O processo de leitura é um diálogo entre autor e leitor mediado pelo texto, que é constituído por ambos nesse processo de interação. $\mathrm{O}$ ato de ler, mesmo sendo realizado individualmente, torna-se uma atividade social. O significado deixa de ser uma questão que diz respeito apenas ao leitor e ao texto para ser controlado pela sociedade. A leitura é o resultado de uma série de convenções que uma comunidade estabelece para comunicação entre seus membros e fora dela. Aprender a ler é mais do que adquirir uma habilidade, e ser leitor vai além de possuir um hábito ou atividade regular. Aprender a ler é ser sujeito-leitor, interpretando sua relação com o mundo, saber-se produzido na linguagem, inscrito num processo histórico, inserido em práticas sociais que medeiam e transformam as relações humanas.

\begin{abstract}
Um segundo aspecto importante a ser abordado no que diz respeito à condição do leitor é a noção de sujeito. É preciso considerá-lo constituído pelo inconsciente e pela ideologia. Estas duas noções mudam totalmente a concepção de sujeito que vigorava até o início do século XX. Ambas abrem a ferida narcísica no modo tradicional de se considerar sujeito. Nem origem dos seus pensamentos, nem livre, nem dono de suas vontades e de sua consciência: o sujeito nesta outra concepção não pode ser pensado como uma evidência ou como uma unidade, reflexo de uma interioridade. (Mariani, 2002, p.108)
\end{abstract}

Quando falamos de leitura e quando falamos de leitor estamos mobilizando uma concepção de sujeito que é, simultaneamente, afetado por processos ideológicos e inconscientes. Uma leitura não é uma leitura, apenas é sempre mais, é uma mistura de possíveis com resultado híbrido, uma outra coisa que está além dela mesma. Conforme escreve Eliana Yunes,

O exercício da memória nunca poderá efetivamente resgatar o fato tal como ele se deu em todas as suas injunções presentes e futuras. A memória fabula, condicionada pelos tipos de registro que se imprimiram em nosso inconsciente. Vem à tona mobilizada por elementos heterogêneos aparentemente, mas por um percurso em que a própria memória se constrói. (Yunes, 2009, p.22)

Sabemos, depois de Sigmund Freud, que a memória não é um depósito arrumado. Ela sobrepõe, mistura, de forma retorcida vai compondo assim a 
identidade. E precisamos mexer nas memórias para conhecer/criar esse "eu" identitário.

Se perguntarmos quem somos, é pela memória que vamos configurando nossa imagem e o que pode ser nossa subjetividade em formação. Félix Guattari, filósofo e psicanalista francês, chama a atenção sobre a subjetivação, em Micropolítica: cartografias do desejo (apud Yunes, 2009, p.32), o processo pelo qual vamos inadvertidamente introjetando modelos, ideias e comportamentos ditados não mais pelo nosso ambiente próximo, mas pela cultura de massas que pesa sobre nossas cabeças. Não há ato de leitura e de conhecimento que não se dê na interação leitor/texto, pessoa/mundo. As interações produzem uma zona movente de sentidos, que se constitui dos contextos múltiplos em que se inserem. Segundo focos e perspectivas atentos ao universo do discurso (a língua posta em uso) podemos ver/ouvir diferentes vozes, animadas por distintas ideologias, que atravessam os textos e os falantes. Somos atravessados por uma permanente intersubjetividade, quer queiramos, quer não. Ela fala de nós e fala sobre nossas leituras.

\begin{abstract}
Na recepção, a abertura e a disponibilidade de si para interagir com uma obra nascem da subjetividade construída pouco a pouco pelas interações com outros sujeitos, outros repertórios, outros acervos. Há que se tenha aprendido escutar e falar para ler e escrever. A recepção de um texto, quer ele se apresente mais fechado em seus sentidos (normas, doutrinas), quer se apresente mais aberto (palavra sagrada, poética), carece de um leitor curioso, estimulado, para se colocar diante da palavra alheia e descobrir a própria. (Yunes, 2009, p.41)
\end{abstract}

A singularidade revela-se nas interpretações de mundo e texto que se nos oferecem. A leitura se dá na interação de quem lê com o lido, e toda leitura é já uma interpretação. Portanto, a formação da pessoa como interlocutora do mundo está ligada aos acervos que partilha e aos repertórios que elege como seus, inclusive seu desempenho expressivo, assentado sobre sua capacidade de pensar singularmente, com originalidade suficiente para que não seja mera repetidora do que ouve sem se colocar criticamente.

Em entrevista que fiz com a coordenadora pedagógica de uma das escolas que pesquisei, ela relatou que o trabalho da oficina Ateliê de Histórias privilegia o imaginário e a liberdade dos componentes, estimulando a criatividade, o gosto por narrativas sem pedagogização, o que em sala de aula acaba não acontecendo, pois 
a leitura parece ter outros objetivos. Os alunos que fazem parte desse grupo desde o início do projeto em 2009, buscaram mais livros na sala de leitura e se apropriaram do que liam com mais naturalidade. Passaram a contar histórias em casa para os irmãos menores ou mesmo para os colegas.

O significado da leitura ultrapassa, portanto, o ato mecânico individual numa prática social e cultural. Uma ação que contribuiu para o crescimento e desenvolvimento de pessoas está inserida na vida cotidiana, na memória, nos livros lidos e nas manifestações sociais e culturais dessa comunidade. A leitura concebida como conjunto de habilidade passaria a paradigma substancialmente outro, para um modelo interativo, que descarta o leitor passivo para buscar um relacionamento ativo com a vida. Colocando em palavras poéticas:

Como uma pipa na mão de um menino, a leitura sem se ater à sua raiz: a raiz da leitura é a mesma que a liberta para o voo, a relação entre a pipa e a mão que não se fixa, nem solta a linha. É semelhante à relação entre o texto e o leitor, que voa sem rotas determinadas a não ser pelo desejo de um e outro de se manterem em linha...(Yunes, 2009, p.44)

Quando entrevistei alguns alunos do grupo de Vila Kennedy, perguntando se trocar oralmente histórias, ler livros, ver filmes ajudaria a imaginar, e se imaginação era importante, responderam que a imaginação ajuda a pensar e viver como personagens diferentes em locais diversos de culturas distantes. Disseram que quando contavam histórias para outras crianças, tanto quem ouvia como quem contava, aprendia também.

Vale ressaltar a fala da orientadora pedagógica de Vila Aliança sobre os "fios" das pipas que representa ter oficinas culturais nas escolas. Oportunidade de vivência artística com trabalhos de contação de histórias, de teatro, de canto coral etc., no meio em que vivem as comunidades pesquisadas, não é comum. Ser artista em escola e possibilitar isso para os participantes, encarados como sujeitos significantes, abre uma janela social que naquelas comunidades seria impensável. Não existe só o prático, o objetivo, o concreto: o imaginário também configura como possibilidade na pluralidade da vida. Os dinamizadores vivem/sobrevivem dos trabalhos em arte- educação, e isso é uma possibilidade de se ganhar a vida através da arte, oportunizando uma experiência ímpar para as crianças.

A maioria dos participantes da oficina na Vila Aliança deixará a escola no ano seguinte e, possivelmente, não serão mais as mesmas pessoas que iniciaram o 
trabalho três anos antes; levarão um repertório de narrativas retiradas de livros que leram, das histórias que trocaram, das associações que fizeram com o seu mundo.“O livro dá consistência à memória humana. (...) Esse vínculo poderoso entre livro e memória faz com que um texto deva ser visto como peça-chave do patrimônio cultural de uma sociedade e, e certamente, de toda humanidade" (Báez, 2004, p.24).

A direção teórica que se estabelece entre leitura literária e leitor remetenos a Freud quando aponta para as dimensões da leitura que se fundam no desejo do leitor. A relação do sujeito com o texto pode ter vários graus de implicação: desarrumar os sistemas de referência do leitor desconcertado pela leitura ou passar em branco, sem nenhuma provocação interna. A modalidade de leitura está relacionada com a intimidade do leitor. "São os fantasmas do sujeito que são colocados em cena, por um instrumento aparentemente tão anódino como o livro e de um deleite pedagogicamente tão instrutivo como a leitura." (Birman, 1994, p.104)

É possível relacionar, porém, a experiência de leitura com a relação de devaneio provocada pela literatura, experiência imaginária do fantasiar matériaprima da criação literária ligada ao sujeito, com atualização feita pelo leitor, rompendo com as codificações instituídas, abrindo possibilidade para produção de outros sentidos. O efeito (surpresa, outro viés significativo) pode estabelecer uma ruptura na leitura, uma suspensão, conduzindo o leitor à fantasia e reflexão, causando um hiato temporal que, ao retomar a leitura, é recomposto para dar sequência narrativa ao texto.

Esse efeito de ruptura se produz de maneira fragmentar e oscilante, pois nem tudo o que está escrito é capaz de tomar literalmente o leitor, mas apenas algumas passagens que incidem na sua circulação desejante. Assim, podemos dizer que a experiência de leitura é um conjunto disperso de fragmentos impactantes, que funcionam pela produção de rupturas no leitor.” (Birman, 1994, p.106)

Dessa forma a leitura literária, como vivência, experiência de prática cultural no ambiente escolar ou fora dele, contribui para formação de leitores que dão sentido ao texto, imprimindo a sua singularidade na experiência da leitura. 


\section{3 \\ Observações das Oficinas de Leitura}

"É a cultura que une o que a economia separa, funcionando como pontes que ligam a cidade partida."

Zuenir Ventura

O Projeto Segundo Turno Cultural, inserido na Coordenadoria de Arte Educação da Secretaria Municipal de Cultura, encontra-se fundamentado no processo de formação da cidadania e em ações de integração das manifestações culturais e artísticas nas práticas de ensino formal e informal. Os desafios prioritários para uma política cultural envolvem o reconhecimento e a valorização da diversidade cultural, disponibilizando a produção de bens culturais a professores e alunos assim como a oportunidade de vivenciar através de oficinas o fazer artístico como expressão, não de forma instrumental.

O Segundo Turno Cultural acontece em 153 escolas, sendo que 150 são Escolas do Amanhã, projeto com apoio da Unesco, para comunidades de risco. São 40 modalidades de oficinas que abrangem as diferentes linguagens (teatro, dança, música, artes visuais, audiovisual, livro e leitura, circo e outras oficinas). O projeto tem como princípio estabelecer uma relação da escola com a cultura do território onde está situada. A relação da produção cultural das oficinas com a comunidade é fundamental e permite que alunos e famílias valorizem seus conhecimentos e se reconheçam como produtores de cultura. O projeto possibilita uma ponte entre o conhecimento formal estabelecido, o patrimônio cultural da humanidade e o conhecimento cultural presente na comunidade. Há ainda ações complementares como a ida de alunos e professores a espetáculos artísticos em teatros e espaços culturais, como exposições.

Esta dissertação, como foi dito, pretende entender o contexto em que se passa o projeto Segundo Turno Cultural, as escolas a que está ligado e como a literatura/leitura, uma expressão significativa do patrimônio cultural, é trabalhada em algumas oficinas. 
As oficinas chamadas de Encontros de Leitura acontecem em uma escola municipal de Santa Teresa no morro dos Prazeres; e o Ateliê de Histórias ocorre em Vila Kennedy e em Vila Aliança; tratei de observá-las e comentá-las nesta dissertação. A oficina Literatura em Rede, nas escolas "Teotônio Vilela", comunidade da Maré, "Coronel Sarmento", comunidade do Alemão e "Chanceler Willy Brandt" na comunidade do Jacaré, onde atuei em 2012 como dinamizadora, acontece igualmente nas Escolas do Amanhã no município do Rio de Janeiro. Destas, trarei meu depoimento.

A metodologia utilizada em minha dissertação corresponde à pesquisa qualitativa etnográfica, cujo foco são as experiências constatadas nas interações dos alunos nas atividades de leitura produzidas em contexto escolar relacionadas com a análise das oficinas através de observação participativa. Foram realizadas entrevistas e coleta de dados dos oficineiros sobre aportes teóricos e sua prática nos grupos, combinando os seguintes aspectos: conceito de leitura do oficineiro, prática escolarizada ou não nas estratégias utilizadas e entrevista com os participantes das oficinas e pessoas responsáveis por seu desenvolvimento na escola.

O fato de o trabalho do Segundo Turno Cultural ser dentro do espaço escolar, embora fora da sala de aula, resgata uma das antigas funções da escola, que é o tempo livre para fruição cultural. A questão da escola proporcionar tempo para fruição e lazer, foi abordado em um minicurso na PUC do Rio de Janeiro, em 25 e 26 de outubro de 2012, "Vir ao mundo, entrar na escola: a hospitalidade da leitura", ministrado por Jorge Larrosa, especialista internacional em leitura e filosofia da educação, retomando a finalidade inicial da escola na Grécia Antiga que era um espaço de acolhimento do ser no mundo. Espaço que legitima o mundo e sua pluralidade, que acolhe os novos seres, numa hospitalidade diferente da familiar, que lida com a identidade de cada um através do "cordão umbilical" que os une que é a língua e a cultura em que estão situados. São alunos que vieram ao mundo e, ao entrar na escola, simbolicamente abandonam o lugar privado de suas casas e entram no público, onde o professor conecta e desconecta as crianças com o infinito, criando um tempo diverso, atemporal para se ocuparem com o mundo, ou melhor, para "brincarem" com o mundo.

\footnotetext{
${ }^{9}$ WWW.leituraemrevista.com.br/4/PDF/LER_n4ano2.pdf Acesso realizado em 15/03/2013.
} 
Nos primórdios, na Grécia antiga, a escola tinha por objeto de reflexão a representação do mundo: o sujeito se distanciava do mundo real, passando a se ocupar de sua representação. Então era possível à escola ser um lugar de identificação do conflito de significados, de relação conflitante entre palavras e pessoas, portanto espaço para o plural, onde todos tinham as mesmas possibilidades; daí o uso do uniforme, não para colocá-los como seres idênticos, mas para deixar evidente a possibilidade de igualdade entre todos. Todos seriam iguais e diferentes simultaneamente.

Em muitos momentos, ainda hoje, professores agem como colonizadores de crianças, sem espaço para elas serem diferentes, com sua história pessoal, não legitimando o direito da criança e o dever da escola na construção da subjetividade. De acordo com Eliana Yunes,

Educar, no entanto, etimologicamente, apontava para outros procedimentos. De ex-ducere - conduzir para fora, trazer à tona, à expressão, o que vive dentro do homem - educação, pelo próprio étimo solicitava estratégias diversas das que então se punham em marcha no processo de escolarização que, lentamente, se expandia. (Yunes, 2002, p.115)

A leitura sob este prisma torna-se, portanto, um ferramental de construção do eu leitor, contradizendo a forma sistemática e arbitrária da escola de nossos dias que trai sua proposta original de tempo livre para o ócio enquanto espaço de criação, sem função pré-determinada empírica, em que tudo seria uma brincadeira sem finalidade marcada, com lugar para ficção, pois o mundo abordado pela escola representaria um exercício distanciado de mundo para melhor tratá-lo, lugar onde a leitura seria exercitada e depois experienciada, exatamente o que acontece nas oficinas de leitura aqui observadas. 


\section{1 Escola Coronel José Gomes Moreira ${ }^{10}$}

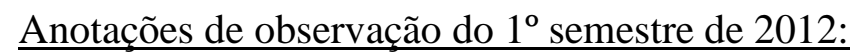

Iniciei minha pesquisa de campo no dia 14 de maio, com a oficina Ateliê de Histórias que trabalha com contação de história e não com narrativa escrita. A proposta compreendia 26 encontros ao longo de 2012, de uma hora cada, sendo que 13 aconteceram no primeiro semestre e os outros 13 no segundo. O espaço oferecido pela escola para que as atividades fossem desenvolvidas foi a sala de leitura. O dinamizador Cadu, responsável pela escola municipal Coronel José Gomes Moreira, situada em Vila Kennedy, esteve na África, trabalhando em oficina de contação de história em uma penitenciária. Retornou em 7 de maio. Os três primeiros encontros foram realizados por um componente do grupo Caleidoscópio Associação Cultural, pois Cadu, ainda não havia retornado de sua viagem à África. No quarto encontro, já com Cadu, as crianças recontaram para ele as três histórias que ouviram. Uma delas, As Três Moças Flor, ficou confusa; Cadu percebe que não entenderam bem, não conseguiram recontar. $A$ interação demanda/ação, não apenas reação, demanda interpretação, e não apenas explicação/compreensão de textos. $O$ texto demanda o leitor e seu repertório de 'leituras'. (Yunes, 2002, p.101)

A partir daí, Cadu escolhe focar o trabalho que desenvolverá nos nove encontros restantes do primeiro semestre de 2012. As crianças passam então a vivenciar a história, discutindo cada ponto, e o dinamizador vai costurando as intervenções orais de cada um.

A estratégia de apropriação e experiência utilizada pelo oficineiro foi de dividir a história em sete partes. Isso aconteceu em 14 de maio com dez alunos de idade por volta de 8 anos. A personagem central da história é uma bruxa que enfeitiça as três moças que viram flor.

A meta final do semestre é montar um "tapete" / painel com as cenas e sair pela escola contando para algumas turmas do colégio a história das As Três

\footnotetext{
${ }^{10}$ Observação em Vila Kennedy grupo com 10 crianças, de 8 a 10 anos de idade
} 
Moças Flor. Os alunos ficaram motivados e participaram falando o que acontece em cada cena, desenhada no tapete/painéis.

O encontro seguinte, que se deu em 21 de maio, continuou com os dez alunos; na sala de leitura, onde ocorre a oficina, há duas mesas bem grandes em que os alunos foram dispostos em dois grupos. Foram escolhidas, dentre as 7 cenas, aquelas que seriam desenhadas para formar o tapete/painel.

As cenas foram as seguintes:

1. A bruxa no alto e as três moças passando;

2. O feitiço transformou as moças em flores;

3. A moça/flor se transforma em mulher e visita o marido;

4. A moça escuta o segredo da bruxa;

5. À noite, ela corre para casa para contar ao marido;

6. Chuva/ a moça espera dentro da casa;

7. De manhã, vai para o jardim; e o marido quebra o feitiço.

Cadu vai cortando os tecidos em 7 quadrados para montarem as 7 cenas que comporão o tapete/painel, e aqueles que foram acabando de desenhar, ajudam-no a cortar os tecidos em partes iguais. Todos participam e têm uma função (contar, cortar, segurar e organizar os desenhos na sequência).

Não participei do encontro do dia 28 de maio, portanto não vi a continuação do processo de criação do painel, mas no dia 4 de junho, os tecidos já estavam cortados, e todas as cenas desenhadas. Em seguida, passaram para a fase de costura, mas logo Cadu concluiu que seria melhor colar, pois os alunos não tinham coordenação motora fina para conseguirem enfiar linha na agulha e costurar os elementos da história que fizeram em tecidos coloridos. Teria sido uma ótima oportunidade para exercitarem controle fino, mas o fato de essa oficina ser de uma hora e não duas como as demais, fez com que a chance se perdesse.

É uma "bagunça organizada", o trabalho com os retalhos de tecidos fornecidos pelo oficineiro. Decidem que o melhor tecido para ser o pano de fundo é o verde, onde colarão os quadrados/cenas. É importante ressaltar que, nesse dia, alguns alunos chegaram atrasados e complicaram o andamento, pois, desentrosados, desconcentram os que estavam dando prosseguimento às atividades.

Cadu disse que quando a criança começa a perguntar menos, fazer escolhas por ela, inicia seu processo de leitura crítico/criativo, voltando para si 
mesma. Lembrando a teoria de Piaget que procura entender os mecanismos mentais que o indivíduo utiliza para captar o mundo, conseguimos ver na prática dessas crianças, a teoria. O oficineiro propõe atividades desafiadoras que provocam um desequilíbrio e no processo de reequilibrações sucessivas, o aluno vai construindo seu conhecimento de forma interativa e autônoma.

Para construir esse conhecimento, as concepções infantis combinam-se às informações advindas do meio, na medida em que o conhecimento não é concebido apenas como sendo descoberto espontaneamente pela criança, nem transmitido de forma mecânica pelo meio exterior ou pelos adultos, mas, como resultado de uma interação, na qual o sujeito é sempre um elemento ativo, que procura ativamente compreender o mundo que o cerca, e que busca resolver as interrogações que esse mundo provoca. (...) é aquele que compara, exclui, ordena, categoriza, classifica, reformula, comprova, formula hipóteses, etc... em uma ação interiorizada (pensamento) ou em ação efetiva (segundo seu grau de desenvolvimento). (...) formação de homens "criativos, inventivos e descobridores", de pessoas críticas e ativas, e na busca constante da construção da autonomia. ${ }^{11}$

$\mathrm{Na}$ semana seguinte, desencontrei-me de Cadu, daí a lacuna de quinze dias. Em 18 de junho, as crianças já estavam com tudo cortado, apesar das tesouras que receberam no material escolar no início do ano letivo não serem apropriadas por serem de baixa qualidade. Tiveram que esperar pelas que Cadu trouxe, por isso só havia quatro tesouras boas. Começam a colagem, e as meninas demoram mais tempo para realizar a tarefa, pois escolhem uma cor, mudam de ideia, acham que o desenho ou colagem não ficou tão boa e repetem a tarefa, mas conversam entre si e solicitam menos o oficineiro, que agora supervisiona a montagem. Quase todas as cenas estão concluídas em seus respectivos quadrados.

Um aluno do grupo que havia iniciado a tarefa faltou, e outros assumiram a feitura da cena, gerando alguns transtornos, pois muitas vezes houve discordância do que já havia sido feito. O líder do grupo teve que intervir, e todos acabaram por se entender.

Dia 9 de julho foi meu último dia de observação desta oficina no primeiro semestre; não pude vê-los contar a história para outras turmas. Nesse mesmo dia, montaram as estratégias para contar aos colegas das outras turmas. O dinamizador trouxe um painel pronto, realizado por outro grupo, e pediu que imaginassem a

\footnotetext{
${ }^{11} \mathrm{http}: / / \mathrm{www} \cdot$ portalsaofrancisco.com.br/alfa/jean-piaget/jean-piaget-1.php Acesso realizado em $28 / 02 / 2013$
} 
partir daquelas cenas representadas no painel, de que tratava a história. Todos ficaram interessados; foram montando uma história e não foi necessário pedir silêncio, pois todos ouviam e falavam criando uma narrativa. Com isso, entenderam que fariam o mesmo, ao contar para os colegas, a partir do seu painel de 7 cenas sobre As Três Moças Flor. Uma aluna ficou muito descontente com a construção de sua cena e sumiu com o que havia feito, dizendo que não participaria mais; porém depois de conversa com o dinamizador, retomou seu trabalho "torto", colado de forma desigual e entrou no grupo para dar acabamento final ao painel montado, e saírem para o encontro com outras turmas, realizando esta etapa do projeto.

Infelizmente não assisti aos alunos saírem em comitiva, batendo nas portas das salas para contar a história a partir do painel. O espaço da oralidade desenvolvido nesse semestre pela oficina de leitura resultou em trabalho de artes plásticas com invento e criatividade que certamente acrescentou muito ao desenvolvimento educacional dos participantes, estimulando processos criativos, desenvoltura na narração da história, desinibição dos componentes. Isso sem falar na convivência, escuta e diálogos estabelecidos a partir da ficção.

Anotações de observação do $2^{\circ}$ semestre de 2012:

Cadu recomeçou o trabalho sem me avisar a data; perdi, pois, os quatro primeiros encontros. A dinâmica desses 13 encontros seria diferente daquela que realizou no primeiro semestre. O planejamento foi contar 4 histórias e trabalhar cada uma durante três encontros. Acompanhei somente uma das quatro, pois houve mudança nos horários.

A experiência que acompanhei dia 10 de setembro, era baseada na lenda Porque a Água do Mar é Salgada e retirada do livro O Ofício do Contador de Histórias. Os alunos não recontam a história, mas dessa vez repetem um refrão a cada pedido feito pelo menino personagem da história. A repetição do refrão foi uma estratégia narrativa na contação para criar uma relação dos alunos com a lenda que vivenciariam. Uma fada deixa de presente um moinho encantado para um menino inteligente que tem o nome de "Boca aberta" e diz que ele poderia pedir qualquer coisa dizendo ao final, as seguintes palavras mágicas: "Moinho 
moa!"; que o pedido se realizaria. Este será o refrão-gancho da atenção que eles devem repetir.

Agora, as narrativas literárias podem ser vistas como membros de uma classe mais ampla de histórias, "textos de demonstração narrativa", elocuções cuja relevância para os ouvintes não reside na informação que comunicam, mas em sua "narratividade". (Culler, 2001, p.33 )

Em seguida, estabeleceu-se um debate sobre desejos e valores: o que é fundamental e qual é a medida das coisas. Uns queriam ser jogadores de futebol, outro ter uma casa, outro que o pai voltasse a morar com a família, que a mãe conseguisse emprego e assim por diante.

Infelizmente só pude voltar no penúltimo encontro, em 26 de novembro, e nesse dia, apenas três alunos compareceram, pois havia acontecido tiroteio no final de semana e, quando isso se dava, na segunda-feira, muitos não saíam de casa. O escritor Bertolt Brecht dizia que Do rio que tudo arrasta se diz violento, mas ninguém diz que são violentas as margens que comprimem esse mesmo rio (Couto, 2009, p.144). Escolas situadas em área de risco, conflagradas pela violência urbana, sofrem com os altos índices de evasão escolar: a violência desencadeia bloqueios cognitivos aumentando os índices de repetência.

Vale ressaltar que no segundo semestre houve muitos desencontros por causa da troca de datas da oficina, o que prejudicou um pouco minha observação do processo. No entanto, como acompanhei de perto o desenrolar das atividades do primeiro semestre, consegui fazer uma ponte, permitindo entender a proposta de narração das histórias e como era aceita pelo grupo. No caso dessa escola, em que a diretora não esteve tão presente no apoio à oficina, nem a orientadora pedagógica, nem a professora da sala de leitura no horário do contraturno, além da troca de datas devido a várias circunstâncias, penso que isso tenha afetado no quantitativo dos participantes e/ou na motivação. O grupo não só não aumentou como muitos alunos faltavam com frequência, bem diferente do que aconteceu em Vila Aliança.

Finalmente o dinamizador permitiu que eu conversasse sobre minha pesquisa e fizesse perguntas tanto aos alunos, como para ele. 
a) Alunos

Pesquisadora: Vocês acham que conhecer histórias, entender textos ajuda na sua formação pessoal/cidadã?

Alunos: Sim, muda nosso jeito de entender muitas coisas.

Pesquisadora: A oficina é um lugar onde as histórias podem ser discutidas. Isso é legal?

Alunos: Sim, discutir, pensar, ouvir e pensar traz muitas ideias. Ter também oportunidade de se expressar; é um espaço muito bom.

Pesquisadora: Quando você lê um texto com ou sem imagem, musicado ou não, representado no teatro ou no cinema o que acontece? Em outras palavras, isto te ajuda em alguma coisa?

Alunos: A história leva imaginar coisas e traz coisas que a gente não sabia; isso é muito bom e divertido.

Pesquisadora: Contar histórias, ler livros, ver filmes lidam com a ficção e mexe com imaginação. A imaginação é importante? Por quê?

Alunos: Imaginação ajuda a gente a pensar. Podemos ser os personagens e estar em locais diferentes. Podemos fazer tudo.

Pesquisadora: Como é contar histórias para os colegas, sair pela escola e ir até as salas com o painel para contação?

Alunos: Legal, ensina a aprender; tanto quem conta como quem ouve aprende. Mas é difícil falar para muita gente.

Acredito que as respostas curtas, sem muitos detalhes, demonstrem o suficiente sobre o que a experiência foi para o grupo. Apesar de pequeno, havia os cativos que sempre estavam dispostos a participar, mas de forma tímida, recolhidos num estado latente de apatia, ou melhor, sem grandes entusiasmos. Talvez como Macabeia, personagem de A hora da estrela de Clarice Lispector, nada de "grandes ousadias". “As expressões: muda nossa forma de ver... muito bom... legal...”. Mostram tudo contido, onde não cabia tanta imaginação. Muito duro o concreto da realidade que os circundava.

Mas é preciso registrar que as interrupções foram causa também de desinteresse dos alunos. 
b) Diretora

P: Como chegou até aqui a oficina Ateliê de Histórias?

D: Em 2010, enviaram o projeto Segundo Turno Cultural, com uma lista de oficinas de diferentes linguagens, e escolhemos a que se relacionava com a leitura, porque este é um problema.

P: Os alunos que participam da oficina frequentam mais a sala de leitura, buscam diferentes obras?

D: Não saberia responder. A professora de uma das turmas que participam da oficina está na escola, e ela poderia responder. (Procurei pela professora, e ela disse que observa que alunos trocam mais de livro. Há uma caixa com livros na própria sala de aula).

P: Qual a contribuição da oficina para o espaço escolar?

D: Favorece a integração e a interação entre as turmas. Compartilham as experiências.

P: Qual a importância da literatura na escola?

D: Favorece e estimula a criação.

P: Quanto ao processo narrativo, os alunos produzem textos? Há alguma atividade que privilegia a escrita?

D: Não tem.

P: Gostaria de apontar algo relevante que não contemplei com minhas perguntas?

D: Acredito que se oferecessem a oficina em outros horários, outras crianças seriam beneficiadas também.

Poderíamos relacionar as respostas da diretora com a fala dos alunos. De certa forma os alunos responderam assim como a diretora de maneira sucinta, sem voos, contidos, sem expectativas pontuais quanto à melhora de leitura e escrita de mundo, com possibilidades criativas e criadoras. A diretora não sabia muito do grupo, pediu que procurasse a professora, e não relacionou sequer a passagem do ler para o escrever.

De certa forma, parece um espaço apático, talvez desgastado. Havia tráfico de drogas bem próximo da escola, coisa que, segundo o dinamizador, não acontecia nos anos anteriores. Talvez as respostas protocolares da diretora nos 
apontem para a insegurança de fora. Daí a indiferença, ou falta de argumentos, diante do fato de não conseguir dar conta de tanta violência.

As entrevistas espelham o trabalho: o grupo participava, interagia e via sentido nas propostas das atividades que eram lúdicas e proporcionava conversa entre eles, tomada de decisão, discussão de conflitos, mas sem grandes empenhos ou emoção que, correlacionado com o depoimento da diretora, fecha a observação. A professora que encontrei, para saber do interesse pela leitura daqueles que estavam na oficina, falou em troca de livro, mas não acompanhou a leitura deles. A fragilidade das relações e a falta de conexão entre os atores, decididamente comprometeu o trabalho.

c) Dinamizador

P: Qual a importância da sua oficina no espaço escolar? Atrapalha a rotina da escola ou contribui no aspecto cultural para a formação de um aluno "bem sucedido"?

D: Acho importante, no meu caso, avaliarmos o que é ser bem sucedido, o que é a formação de um aluno que objetiva ser bem sucedido. Sou uma intervenção artística dentro do espaço|tempo escolar. Fico uma hora semanal em 26 encontros ao longo de um ano. E cada encontro é um jogo criativo, de muita escuta de ambos os lados (dos alunos e o meu), de muita mediação para que os nossos processos criativos possam ganhar uma dimensão concreta e, por isso, mesmo poética. Ser bem sucedido, a meu ver, é poder ter e fazer parte de um espaço|tempo onde podemos vivenciar o imaginário nas correntezas da criatividade, cercado pela dura realidade. Se todos nós que nos encontramos nesta uma hora semanal vivemos isso, aí acho que somos bem sucedidos, e irradiamos e contaminamos todo o nosso espaço|tempo de convivência (tanto o dos alunos, quanto o meu, dinamizador): a própria escola, os amigos, a família, os lugares que frequento etc.

P: Para Alberto Manguel "o livro é como o ser humano, ou o ser humano é como um livro, o autor como leitor, o leitor como autor, o mundo como um texto ou um texto como o mundo." Como vê sua oficina na tarefa de ler o mundo?

D: Citando Eduardo Galeano, é como dar a mão para o aluno ver o mar/mundo. É ler as infinitas possibilidades de imensidão do mar. Criar um mar, fazer falar de mar.

P: Como planeja a experiência da leitura?

D: Cada semestrelano é de um jeito. Algumas vezes experimentamos a história de forma tátil (apago as luzes e ficam de olhos fechados), noutros na escuta do outro, outra forma é a produção artística como expressão. E até mesmo discutir com as crianças a estrutura da história e os pontos de relação com o mundo que ela toca. 
P: Como estimula a capacidade de estabelecer analogias entre os vários sistemas de linguagem?

D: Através de atividades plásticas, dramatização, fotografando, relacionando-as e se apropriando de outras linguagens.

P: A leitura é condição de aprendizagem. A ficção é capaz de libertar sonhos e desejos. Qual o papel político ao promover essa possibilidade de construção do leitor aqui no projeto Segundo Turno Cultural?

D: O papel é de construir/estabelecer possibilidades de uma ética pela estética. Ressignificar o espaço educacional como também um espaço cultural. Somos todos fazedores de cultura. Perceber-se pertencente e agente transformador do mundo ao meu redor e do que não está ao meu redor.

P: Somos leitores desde o momento em que abrimos os olhos pela primeira vez. Quando o aluno passa a dominar textos mais complexos, torna-se leitor fluente, competente e crítico. Seu trabalho contribui para formar pontos de vistalleitor, conviver com outro/alteridade ou apenas se propõe a abrir "janelas", livros como forma de conhecimento?

D: Através das narrativas, pretende-se criar um terreno fértil envolvendo professores, coordenação, alunos, para que a narração de histórias cresça e se desenvolva na escola como um todo e contribua para formação de um ser cidadão sensivel, permeado de fantasia e de renovação da realidade. Acredito que meu trabalho contribua para a abertura, sim, de "janelas", de re"visões" da realidade, de si e do outro, no entendimento que somos a partir do jogo com o outro.

P: A literatura promove autonomia no pensar e no agir do leitor?

D: Depende de que tipo de literatura estamos falando e de qual leitura fazemos. Algumas podem promover um processo de autonomia inesgotável, outras são piores que lobotomia, porque nos transformam em zumbis eternos, com sequelas graves de reconhecimento de ser.

Interessante Cadu falar da importância de trazer poesia, numa realidade nada poética, num lugar mal tratado pelo poder público. Através do que observei no trabalho do dinamizador, vi que a poesia estava na forma como conduzia as atividades. Muita escuta, talvez seja esse o segredo para um ambiente calmo, não muito comum na escola, escutar. Com um jeito simples e acolhedor, remeteu-me à fala de Jorge Larrosa ${ }^{12}$, quando se referiu à escola na Grécia antiga como espaço público que acolhe o aluno, o sentido de hospitalidade. Penso que acolher o outro tal como é, viabilize a aproximação com o mundo literário. Aqueles que ficam e

\footnotetext{
${ }^{12}$ Em palestra proferida na PUC-Rio, patrocinada pela Cátedra UNESCO de Leitura em outubro de 2012.
} 
participam de sua oficina, realmente não serão os mesmos, como a leitura de um bom livro faz com seus leitores.

Contudo é muito grave que as próprias respostas dos adultos entrevistados mostrem a dissociação entre as metas e os resultados e a falta de percepção do que está ocorrendo de fato.

\section{2 \\ Escola Ayrton Senna ${ }^{13}$}

A observação da oficina Ateliê de Histórias, também a cargo do grupo Caleidoscópio Associação Cultural, começou em 14 de maio de 2012, tendo o mesmo dinamizador da escola de Vila Kennedy. Portanto, toda questão apontada na escola anterior se aplica a esta, ou seja, já tinham ouvido três histórias, um contador tinha substituído o dinamizador nos três primeiros encontros, porque ele estava fora do país, quando as atividades do projeto do Segundo Turno Cultural começaram. A diferença é que a história que não conseguiram recontar foi a Árvore da Canela, e daí partiu o trabalho do dinamizador nos mesmos moldes da escola Coronel José Gomes Moreira.

É importante salientar que os encontros nem sempre se deram na sala de leitura, que nessa escola é também sala de informática. A estrutura física da escola Ayrton Senna é semelhante a da escola Júlia Lopes, no Morro dos Prazeres em Santa Teresa. É pequena, com salas de aula apertadas, sem quadra de esporte (há espaço um pouco maior para as aulas de Educação Física e para o projeto de música/banda, que funciona também como auditório, no final de corredor). A escola foi construída em cima de uma pedra, ficando no alto de um condomínio fechado, com um único andar. Nesse andar, além das salas de aula, há secretaria, sala de professores, refeitório e cozinha, banheiros, sala de leitura/informática e espaço para atividades maiores, como já dito, no final do corredor. Há também um espaço amplo após a escadaria, quando se atinge o andar onde está construída a

\footnotetext{
${ }^{13}$ Vila Aliança (número médio de participantes 15, com idade em torno de 11 anos).
} 
escola, onde se recebe os alunos para a entrada e um pequeno pátio. Alguns encontros da oficina foram realizados nesse pequeno pátio, por estarem ocupadas todas as salas.

Anotações da observação do $1^{\circ}$ semestre de 2012:

No dia 14 de maio, os alunos recontaram a história da Árvore da Canela e o dinamizador foi anotando num flip board o que eles iam dizendo:

1. Um menino que adorava a natureza;

2. Encontra uma andorinha ferida;

3. Andorinha traz semente de cabaça;

4. O menino planta a semente com carinho;

5. Árvore cresce;

6. Corta a cabaça e seu interior está cheio de pedras preciosas e ouro;

7. Todos ficam felizes, menos um jovem porque ficou com inveja;

(Há uma discussão: Quem gostaria de ganhar uma cabaça?)

8. O menino invejoso fere uma andorinha e cuida dela;

9. Andorinha traz uma semente de cabaça;

10. Planta de qualquer jeito a semente de cabaça;

11. Árvore cresce;

12. Ao cortar a cabaça, sai do interior um anão verde que fica escrevendo;

13. O jovem sobe com o anão a árvore da canela e pergunta como fazer para ficar rico;

14. A riqueza fica na lua cheia, diz o anão, e é para lá que vai o menino;

15. Depois de um tempo, cansado de ficar na lua, queria voltar para a Terra, e o anão tem que cortar a árvore da canela para realizar o desejo do menino.

O dinamizador termina o encontro com a seguinte tarefa para casa: os alunos deveriam pensar sobre o que é riqueza e o que é pobreza, e como mudar essa situação.

No dia 21 de maio, ele recomeça lembrando o dever de casa. As respostas foram as seguintes:

- É difícil imaginar o mundo com estrutura diferente, entre o rico e o pobre; 
- Os ricos jogam fora a comida que sobrou, isso o pobre não faz, porque falta comida;

- Em países “capitalistas”, o lema é lucrar;

- Já nos países “socialistas", todos ganham a mesma quantia; uniforme igual para todo mundo;

- Isto decorre do fato de que no encontro anterior, o dinamizador conta o que viu na Alemanha dentro de um vagão de metrô. Os passageiros não têm que passar com o ticket por uma catraca, mas todos pagam e mantém o comprovante consigo. Às vezes, um funcionário vem pedir o ticket dos passageiros dentro do vagão. Alemanha é um país rico, todos pagam impostos e os custos com transporte, mas não há uma pessoa que regularmente cobra os comprovantes. O povo entende seu papel de cidadão. Então riqueza está relacionada com compromisso ético e moral. Não dá para ser rico sozinho e ficar numa lua, não faz sentido. Ele tentou expressar a questão da desigualdade falando de capitalismo e socialismo.

Nova tarefa para casa: Cada aluno desenhará uma cena das 15 frases listadas.

Não pude ir aos próximos três encontros, trocaram a data da oficina. Voltei no dia 18 de junho e encontrei os 15 panos desenhados. Seis alunos escolheram costurar as figuras de sua cena, e os outros nove decidiram colar. Todos passaram o encontro fazendo tranquilamente essa tarefa. Ao final, o dinamizador recolheu os panos e os guardou para prosseguirem o trabalho no próximo encontro.

Motivos de família foram a razão da minha ausência nos dias 25/06 e 02/07, mas felizmente cheguei a tempo no dia 9 de julho para ver como ficou o painel que montaram e como contaram para as outras turmas a história da Árvore da Canela.

Todas as salas estavam ocupadas, e o encontro aconteceu no pátio da entrada da escola. Sorte que era finalização do trabalho do semestre e não precisavam das mesas para apoiar.

Alguns componentes faltaram e já haviam distribuído as funções para a hora de contar. Pequena confusão para se reorganizarem na divisão das tarefas. O dinamizador já havia combinado com a orientadora pedagógica quais seriam as turmas que entrariam para contar a história. 
Saem em procissão pelo único corredor da escola, vão cantarolando um pequeno refrão e batem na porta das três turmas que aguardam o grupo. $\mathrm{O}$ primeiro grupo contador da história estava com muita vergonha e acabou falando muito baixo. O segundo grupo contou melhor, mas o painel caía e trouxe um certo constrangimento. O terceiro grupo contou bem melhor, lembrando do título, detalhando mais, explorando melhor o painel, e com impostação de voz mais clara e firme. Em todas as três salas que estiveram, contaram com a atenção e a colaboração dos colegas que ouviam. Das turmas que atuaram como espectadores da história contada pelos grupos da oficina, aquela composta por crianças menores foi a mais interessante, pois além de prestarem atenção aos contadores, o olhar era de admiração pelos mais velhos que conseguiam dar conta de tarefa tão "nobre" e difícil.

Terminando as três apresentações, ficaram mais confiantes e menos tímidos, quiseram improvisar mais uma. Então os grupos se misturaram e só participou quem estava mais empolgado e seguro. Dessa vez, conseguiram olhar nos olhos da plateia, e houve uma interação maior entre contadores e ouvintes. Aqui o resultado pareceu, então, envolver os alunos e devolver algo à escola. Gostaram muito.

Anotações da observação do $2^{\circ}$ semestre de 2012:

Como as duas oficinas aconteciam no mesmo dia da semana, e não fui avisada da data do reinício, e de novo perdi os quatro primeiros encontros. A dinâmica desse semestre da oficina Ateliê de Histórias foi igual nas duas escolas, como ocorreu no primeiro semestre, só mudando a história, mas o trabalho foi realizado sobre aquela que não conseguiram recontar. Como aconteceu com a escola de Vila Kennedy, acompanhei somente uma das quatro histórias, pois houve mudanças nos horários. A estratégia era o trabalho oral com narrativas que se desdobravam em alguma atividade lúdica.

Segundo Ramal (2000), 
Nas culturas que não conheciam a escrita, a transmissão da história se dava através das narrativas orais: o narrador relatava as experiências passadas a ouvintes que participavam do mesmo contexto comunicacional. Era uma espécie de história encarnada nas pessoas: quando os mais velhos morriam, apagavam-se dados irrecuperáveis pelo grupo social. $\mathrm{O}$ saber e a inteligência praticamente se identificavam com a memória, em especial a auditiva; o mito funcionava como estratégia para garantir a preservação de crenças e valores. O tempo era concebido como um movimento cíclico, num horizonte de eterno retorno. (Ramal, 2000, p.21)

Dentro dessa lógica oral/auditiva, acompanhei, a partir do dia $10 \mathrm{de}$ setembro, a lenda de como a água do mar ficou salgada, só que dessa vez os alunos repetindo refrão a cada pedido do menino e também para parar o feitiço, deveriam usar as palavras mágicas "Todo começo é o princípio do fim”. Então, depois de ter pedido sopa de carne, leite batido, entre outras coisas, resolveu pedir sal, matéria muito valorizada naquele reino, assim pensava que se tornaria rico. Estava dentro de um barco, quando fez o pedido, mas se esqueceu das palavras mágicas para parar de receber sal. Com isso, o barco foi se enchendo de sal, pesando e afundou. Ele acabou morrendo, e todo o sal se espalhando pelo mar. Talvez seja por isso que a água do mar é salgada, diz a lenda.

O passo seguinte foi cada um do grupo imaginar um moinho encantado e fazer um pedido para que fosse realizado. O pedido recorrente foi ligado a dinheiro, ficar rico e ter muito ouro. Como resposta, o dinamizador conta a história do rei Midas. Se tudo vira ouro, mas não se pode desfrutar dele, então como fica a questão do \$? Ficaram surpresos ouvindo a história do rei Midas.

No encontro de 3 de dezembro, realizei meu "questionário", e depois fomos ouvir uma contação de história com o Grupo Mosaico, naquele espaço maior que fica no final do corredor, juntos com as outras turmas. O último encontro seria um passeio em Santa Teresa. Como os alunos estavam concluindo o primeiro segmento do Ensino Fundamental, ganharam esse presente da escola, e lá o dinamizador fecharia as atividades. Isso ocorreu em 12 de dezembro e como não pude acompanhar, soube, em conversa com o dinamizador na reunião de final de ano do Segundo Turno Cultural em 14 de dezembro, no Calouste Gulbenkian, que pediram para ele comparecer à formatura na escola, que já acontecera no dia anterior.

Um convite para ocasião tão significativa na vida deles, conclusão do primeiro segmento do Ensino Fundamental, para o dinamizador revelava a 
importância do que viveram na oficina, as histórias ouvidas faziam parte da formação deles. A presença do oficineiro era importante para o grupo que esteve junto nos três últimos anos. Os pais dos alunos que participaram da oficina de leitura fizeram questão de conhecer o dinamizador, pois relataram que, além de as crianças gostarem do trabalho, contavam em casa as histórias que ouviam na oficina para os irmãos menores e até para os pais. Agradeceram a motivação que havia proporcionado para que buscassem mais livros, o que foi confirmado em entrevista com a orientadora pedagógica.

Desta vez a entrevista ouviu os alunos e a orientadora pedagógica.

a) Alunos

P: Você acha importante conhecer histórias, entender textos?

A: Tem importância porque é parte da memória, do conhecimento e umas estão mais ligadas ao real e outras são mais encantatórias.

P: Você acha que só nas oficinas é que dá para discutir as histórias, ou no turno normal também se consegue trabalhar leitura?

A: Apesar de o grupo de sala de aula ser grande (mais de 30 alunos) e ser difícil discutir, num grupo maior, mais gente tem oportunidade de aprender também.

P: Quando você lê um texto com imagem, musicado ou não, representado no teatro ou no cinema ajuda sua leitura? Como é uma leitura no livro e no computador?

A: Parece mais interessante quando o texto tem música, com imagem e ilustração fica mais emocionante, facilita a compreensão e ajuda aqueles que não gostam de ler, ou não sabem. Ler no computador é melhor porque podemos até fazer perguntas.

P: Contar histórias, ler livros, ver filmes faz a gente imaginar. O que faz a imaginação?

A: É uma forma de aprender a cultura.

P: Como é passar as histórias, ir às salas contando, montar painéis?

A: É bom repassar as coisas boas. Mostrar o que a gente aprendeu, para os outros conhecerem aquilo que a gente entendeu, sair multiplicando.

Pode-se perceber bem a diferença entre as crianças de uma e outra escola através das respostas que deram. Neste grupo, elas são mais prolixas, são mais 
velhas que as anteriores, logo os argumentos apresentam desdobramentos, com mais maturidade para idade. Atribuo ao acompanhamento que é efetuado pela direção, somado ao compromisso da área pedagógica e do corpo docente, além, claro, da condução do dinamizador. Esses alunos, ao saírem da escola, levarão cadernos de memória como registro de ideias e do progresso escolar e pessoal. Eles são privilegiados por estarem num espaço escolar organizado e mais atento, que recebeu prêmio pelo desempenho dos alunos. O acompanhamento que recebem dos gestores é melhor do que o realizado em muitas escolas públicas que não convivem com a violência tão próxima.

b) Orientadora pedagógica

P: O que traz a oficina Ateliê de Histórias para a escola Ayrton Senna?

OP: As crianças que participam da oficina há 3 anos contam histórias para o irmão menor e para os pais. O dinamizador ser homem e promover leitura sem formalidade de preenchimento de fichas ou outras cobranças dentro de uma escola é muito importante. Em sala de aula, os alunos daqui são estimulados a ler, mas não trabalham o imaginário, o sonho que a literatura promove. A leitura e a escrita têm sempre tom pedagógico quando acontecem dentro da sala de aula. O professor é resultado de uma escola castradora e, sem perceber, deixa de estimular a criatividade do aluno.

P: Os alunos que participam da oficina se interessam mais por ler histórias, buscam mais livros na sala de leitura?

OP: Sim, e são acompanhados pelo professor de leitura da escola que oferece outros livros e analisa as ilustrações, a obra em seu conjunto.

P: Como é a contribuição artística da oficina Ateliê de Histórias?

OP: O dinamizador é um artista, cidadão do mundo, e vive do seu ofício. Ganhar dinheiro é importante, mas há diferentes formas de se ganhar dinheiro para viver. Ele traz o plural, desperta a personalidade dos alunos para algo diferente. Os alunos esperam pelo dia da oficina.

P: Qual é a importância da literatura na escola? Há espaço para ela?

OP: Há momentos de leitura com a professora, roda de livros, sala de leitura. Aqui o livro está sempre circulando.

P: Quanto ao processo de escrita, os alunos produzem textos também?

OP: Há um caderno que guarda memória de como a criança vai se expressando e registrando os avanços. 
P: Gostaria de apontar algo relevante que não contemplei com minhas perguntas?

OP: $O$ aluno que tem baixo rendimento, com dificuldade, é o que privilegiamos. Aqueles que apresentam bons resultados são estimulados a ajudar e ceder lugar para os que precisam mais, há uma cultura de solidariedade nessa escola. Ela vem sendo construída há muitos anos. A pessoa que implantou esse olhar pedagógico, já se aposentou, não está mais aqui, mas continuamos entendendo que nosso esforço tem que se direcionar para os que não atingem a meta. A oficina, a forma como é conduzida, potencializa para que ninguém se sinta a ovelha negra.

Relendo o que observei e ampliando o olhar, percebo três itens que diferenciam a literatura escolarizada da literatura praticada na oficina Ateliê de Histórias:

1. A dinâmica sensível do mediador. Ele consegue desenvolver uma didática associada a várias linguagens, organiza para os alunos uma tríade: linguagem interna (pensamento) para linguagem oral (expressão) para a formatação da linguagem escrita. Em todo ambiente cíclico de sua prática, há liberdade de expressão, discussão de ideias e interpretação de textos.

2. Escapar da formatação escolarizada do sistema educacional vigente propicia o foco no processo e não nos resultados. A narração de histórias, as manifestações narrativas contribuem para a construção da subjetividade e do olhar atento dos alunos, trabalho precioso para a formação de leitores.

3. Na escola que possui acompanhamento cuidadoso e minucioso do desempenho pessoal e intelectual dos alunos integrado às práticas (registro da evolução textual individual, o caderno memória; roda de leitura; cultura solidária etc.), os resultados da oficina são mais positivos, o que comprova a importância da proposta ser integrada entre "primeiro"e "segundo" turnos da escola (o educativo e o cultural). 


\section{3 \\ Escola Júlia Lopes de Almeida}

A oficina Encontros de Leitura na escola Júlia Lopes de Almeida propõe trabalhar textos numa perspectiva oral, contando histórias sobre as relações do homem com o mundo, mediadas por sua percepção e construídas pela linguagem. Histórias como maneira de recuperar memória com ajuda da fantasia em que personagens, muitas vezes animais, com o comportamento parecido com os da natureza humana ou não, tratem das dores, conflitos, paixões que projetam os alunos em ficções criadas pela imaginação e proporcionem um reencontro com o prazer de ler.

\section{Anotações da observação do $1^{\circ}$ semestre de 2012:}

Fiquei pensando em como poderia escrever sobre o que observei ao longo de seis meses das atividades da oficina Encontros de Leitura, na escola Júlia Lopes de Almeida, e decidi correlacionar com a mostra que vi no $\mathrm{CCBB}$, em 2008, sobre Clarice Lispector e sua obra. Seria bem interessante, pois possibilitaria para os leitores da dissertação, que certamente conhecem um tanto da obra da escritora e talvez tenham ido à referida mostra, entender o que se passou com a leitura, ou melhor, com o grupo de mais ou menos dez alunos (havia mais inscritos), que frequentaram a oficina, objeto da minha pesquisa.

Descrever a estrutura do espaço dessa escola é muito importante, elucida muitas coisas que observei: é um prédio vertical, construído numa encosta, sem terreno ao redor, sem uma entrada tradicional. Entra-se pelo refeitório e à direita da porta principal encontram-se as escadas que levam para as salas de aula, distribuídas em dois andares - sala de atividades físicas, sala de arte, sala de leitura junto com os computadores, isto é, um laboratório de informática, além de banheiros. Se, ao invés de subir as escadas à direita, segue-se em frente, atravessando o refeitório com a cozinha ao final, encontra-se uma sala compacta, para a direção e orientador(es) pedagógicos, com dois banheiros adaptados para todos os funcionários da escola.

O prédio era inteiramente atípico, sem semelhança com qualquer outra escola. Tudo é compartimentado, lembrando as pequenas gavetas da exposição 
com os textos e fotos de Clarice. Insisto nessa ligação porque, se não se é alguém que esteja com um propósito determinado (querer visitar a mostra e ser iniciado nos textos de Clarice), ou não seja bastante curioso (abrir as gavetas), não vai produzir uma leitura; em outras palavras, entender esse espaço escolar, que atendeu em 2012, a 317 crianças da primeira fase do Ensino Fundamental, estruturado como as "gavetinhas" da exposição, que necessita de pessoas para fazer a ligação entre elas, é decisivo para avaliar o processo.

É complicado entrar num espaço cheio de pequenas gavetas sem o "fio" que liga umas as outras, o fio da motivação e do fazer sentido, para poder abrir mais e mais gavetas. Os professores, funcionários, alunos, oficineiros acabam tendo que entrar numa dessas portas/gavetas, mas já sabendo o que buscam. Quem ama Clarice e seu estilo fragmentado de escrita certamente vai ficar muito curioso com a possibilidade de encontrar seus textos poéticos, as cartas que recebeu e escreveu, nas diversas gavetinhas, mas se o visitante não conhecer a autora minimamente, abre uma, a segunda e, na terceira, segue sem conseguir ver sentido em uma sala com gavetinhas. O mesmo ocorre na escola Júlia Lopes de Almeida: se não houver um objetivo específico para entrar naquele espaço, perde-se, porque não se encontram diretora circulando, crianças correndo em pátio, um hall para acolher quem chega, e então se vai embora, sem entender o "conteúdo" das gavetinhas, o quebra-cabeças do edifício da escola.

Ressalto que essa exposição de Clarice foi bem polêmica quanto à proposta de "gavetinhas", não sendo bem aceita pelo público que a visitou. Muitos ficaram descontentes por não encontrarem informações que julgavam importantes para a compreensão da obra e da autora. Ou seja, até mesmo quem tinha o "fio" condutor de Ariadne, não simpatizou muito com informações expostas de forma tão fragmentada. Foi uma abordagem artística, uma leitura que a muitos estudiosos da autora desagradou; mas seria compreensível em um espaço onde a criatividade prevalece. E como seria uma escola "gavetinha", vertical, cujo espaço carece de condições de intercomunicação básicas para seu funcionamento?!

Tendo em conta a descrição acima, as atividades da oficina Encontros de Leitura apresentaram uma dinâmica bem diferente das duas anteriores. As crianças eram menores, em torno de 7 anos no máximo, todos do turno da manhã, e ficavam após o lanche das 11 horas e trinta minutos para duas horas de 
atividades que começavam ao meio-dia. Elas sempre ocorriam na sala de leitura/informática e, como o grupo não era grande, cabiam bem no espaço.

Normalmente os dinamizadores (eram dois sempre) iniciavam contando uma história, seguida de atividades lúdicas tais como: desenhar cenas da história, imitar um dos personagens (trazer para o corpo a questão central, para assustar, cantar, transformar-se em letra), brincar de telefone sem fio, criar algo artístico/simbólico que retratasse a interpretação do que ouviu. O segundo momento era dedicado às caixas da biblioteca que continham livros para sua faixa etária: eles mesmos escolhiam o que ler. Muitos ainda não liam fluentemente, o que trazia muitas frustrações, pois passavam de um livro a outro sem se fixar nas imagens e nas letras, e isso se repetiu sempre, sem que os oficineiros mudassem seu método.

Depois formavam uma roda no chão, e cada um contava o que havia lido no livro que escolheu (aqueles que não dominavam a leitura, não conseguiam participar e acabavam por tumultuar o grupo). Quando havia tempo, faziam um relaxamento no final do encontro. Quando estavam muito agitados, o relaxamento era no início. Importante ter em mente que essas crianças já tinham ficado 5 horas nesses espaços apertados.

Iniciei minha observação no dia 8 de maio de 2012. Os oficineiros escolheram trabalhar por tema, ou seja, as histórias estariam entrelaçadas pelo assunto central. No primeiro semestre, o tema foi valor e no segundo, medo. Felizmente pude acompanhar mais de perto essa oficina, pois quase não alteraram o dia da semana. Conforme expliquei anteriormente, havia uma rotina (ouvir história, produzir algo artístico ou lúdico como interpretação, leitura do acervo da biblioteca, partilha do que leram). Os primeiros encontros do primeiro semestre foram baseados na história As Botijas de Ouro, de Joel Rufino dos Santos.

Eles fizeram um móbile com forminhas douradas imitando moedas de ouro, etiquetadas com valores que achavam preciosos (família, amizade etc.). Esse trabalho foi exposto na FLIST (Feira Literária de Santa Teresa) que ocorreu no Parque das Ruínas no início de maio do mesmo ano. A partir dessa história, os alunos criaram em caixas de sapato suas botijas, que foram expostas para a escola, na sala de arte, no início do segundo semestre; e depois para a reunião de pais. Poucos alunos foram visitar a exposição dos trabalhos, as professoras não levaram suas turmas a esta "gavetinha". 
No dia 15 de maio, a história que ouviram foi sobre o veado que tinha pernas muito longas e não gostava nada delas. Só que graças a elas conseguiu fugir do leão. A questão ligada ao corpo é sempre muito bem-vinda para os alunos. Nesse dia, pegaram livros que tratavam do corpo e de sexo. O momento da roda girou em torno das seguintes questões: Somos iguais em quê? Se havia alguma parte de que não gostavam em seu corpo?

A brincadeira dessa vez foi fazer com o corpo uma letra, e os outros adivinharem a letra.

No encontro seguinte, em 22 de maio, a dinâmica mudou um pouco. Os alunos contaram para os que faltaram na semana anterior a história do veado e do leão. Conversaram um pouco e ouviram uma nova história sobre uma cidade em que o prefeito mata os ratinhos. Desenharam o que chamou mais atenção nessa história e, aqueles que iam terminando, pegavam suas "botijas". Em vários encontros foram construindo cada um a sua botija com material reciclável. Dentro colocavam o que lhes parecia valioso.

No dia 26 de junho, a professora de turma faltou, por isso as crianças não puderam ter oficina, que seria a última do semestre. A oficina acontecia após o turno escolar, e esta foi a única falta da turma em todo o projeto. Infeliz coincidência, já que seria o fechamento dos trabalhos, comprometendo a avaliação.

Anotações da observação do $2^{\circ}$ semestre de 2012:

Nos três primeiros encontros depois do recesso de julho, as crianças, com os mesmos oficineiros trabalharam nas "botijas" e organizaram o espaço na sala de arte para expor os trabalhos do semestre anterior, a serem visitados pelos pais que comparecessem à reunião de abertura do semestre.

O tema do segundo período, como já dito, ficou centrado em histórias cujo enredo tratasse de medo. Selecionaram alguns livros do acervo da biblioteca e deixaram os alunos manusearem por um bom tempo. Depois escolheram uma história lida em tom assustador como provocação. Nesse dia 28 de agosto, terminaram o encontro com cada aluno contando algo assustador que havia vivido/visto/lido. 
Como eu havia trabalhado em minha oficina o livro de Angela Lago, Sete histórias para balançar o esqueleto, sugeri que lessem os contos. Gostaram da ideia e fizeram os dois encontros consecutivos (4 e 11 de setembro) baseados na obra. Trabalharam a questão das cores escuras, tendo o branco como a cor da assombração: todas as páginas eram escuras e a capa de fundo preto; as letras e ilustrações tremidas; enfim, texto e imagem dos contos se complementavam.

O dinamizador apagou as luzes da sala para entrar no clima das histórias. Os alunos complementaram o final de algumas e acabaram entendendo que quando nos tornamos "donos" das histórias, o medo desaparece.

No dia 18 de setembro, usaram uma outra estratégia em que a história não era lida, mas criada pelos participantes. Tratou-se de uma história que se passam num cemitério. Criaram cenário com retalhos de malha, amarrados até formar uma bola. Depois, com tecido amarelo, amarraram uma vassoura que representava uma árvore morta. Um menino desobediente, personagem da história, faz cocô num campo santo, o cemitério, o que pareceu engraçado por se tratar de algo escatológico. Importante apontar que a história foi sendo criada por todos, ao mesmo tempo em que era encenada. A bola era o cocô que o menino foi arrastando pelo cemitério e acaba por sujá-lo todo. Ele ganha o apelido de Cagado, depois dessa experiência terrível. Resolve, então, não ser mais do contra e respeitar regras e lugares. Uma história repressiva e punitiva, mas com um resultado surpreendente.

A estratégia de criarem uma história em que o personagem central era um menino desobediente veio a calhar porque o grupo estava se comportando muito mal. Não conseguia fazer silêncio nas horas solicitadas, não cumpria as tarefas com capricho e, frequentemente, atrapalhavam uns aos outros. A história "chocante" que criaram no cemitério fez com que rompessem a rotina dos encontros anteriores em que os dinamizadores sempre precisavam parar para chamar atenção, situação de enorme desgaste, ocorrida com frequência durante os encontros. Dessa vez, eles perceberam que eram agentes e pacientes da história

$\mathrm{Na}$ semana seguinte, uma menina do grupo recontou a história do menino desobediente para aqueles que faltaram à oficina anterior. Nessa "peça", havia uma música engraçada, e amaram recomeçar os trabalhos por ela.

Desde o início de agosto, muitos não retornaram para a oficina. No Casarão dos Prazeres, bem ao lado, começaram a oferecer atividades gratuitas de 
dança, jogos, lutas marciais, entre outras modalidades, e boa parte do grupo preferiu sair. As atividades aconteciam no mesmo horário da oficina. A secretaria de Cultura enviou responsável para ver se manteriam os trabalhos ou se teriam que fechar a oficina do Segundo Turno. Certamente oferecer algo que fosse fora do prédio inadequado, onde pudessem correr e brincar, seria mais atraente do que uma oficina lúdica de leitura numa "gavetinha". Estranho é não proporem, para os responsáveis pelo Segundo Turno Cultural, um projeto em parceria com a Secretaria de Educação de transferir a oficina para o Casarão. Voltaram a divulgar a oficina, e outros alunos se inscreveram. Mais da metade do grupo era novo, o que significava descontinuidade no trabalho/aproveitamento dos meninos.

Apesar das grandes dificuldades atravessadas por falta de disciplina, com alunos novos descontextualizados (atividade já estava em andamento desde abril de 2012) e alguns não dominarem os códigos de leitura, os trabalhos prosseguiram e findaram com a leitura do livro Mas por quê? de Peter Shössow. Nesse momento, houve uma troca de dinamizador. Um precisou se afastar para cirurgia na mão. Os encontros seguintes foram releitura do texto, discussão da história. Assistiram aos clipes e definiram quem representaria os personagens da história que foi adaptada do livro para uma peça teatral.

Nos encontros seguintes, os alunos ensaiaram a peça que foi apresentada nos dois turnos na semana do projeto da secretaria de Cultura, Paixão de Ler. Importante registrar a participação do coral da escola. Ele fez a parte musical da peça que tratava de um passarinho chamado Elvis, que morre. Na peça, adaptada do livro, introduzem um clipe de Elvis Presley com alunos imitando o cantor. Nessa data, quando se deu a finalização das atividades do ano da oficina Encontros de Leitura, a plateia ficou em êxtase, vendo colegas atuando, cantando e tocando instrumentos. A direção, professores, funcionários, enfim, todos se uniram no refeitório que se transformou em um teatro, e as "gavetinhas" passaram a fazer um grande sentido quando unidas num espetáculo cultural dentro da escola executado por alunos.

Mas não é possível deixar de notar a passagem da história do passarinho para o clip de Elves Presley que foi usado como mobilizador da plateia, deixando de lado o sentido da história.

Entrevistei os dinamizadores no final das atividades da oficina. 
P: Qual a importância da sua oficina no espaço escolar? Atrapalha a rotina da escola, ou contribui no aspecto cultural para formação de um aluno "bem sucedido"?

D: Atrapalha de forma positiva, desconstrói a rotina. Tira da acomodação, da cristalização, porque traz um modo de olhar e agir ligado às artes, que têm uma dinâmica bem diferente da que se dá na escola, uma liberdade e até um certo "caos" que fazem parte do processo de criação artística. Contribui com a pluralidade e com a formação do aluno, no sentido de abrir para a descoberta de outros dotes e interesses muitas vezes não abordados ou pouco explorados pela escola.

P: Para Alberto Manguel, "o livro é como o ser humano, ou o ser humano é como um livro, o autor como leitor, o leitor como autor, o mundo como um texto ou um texto como o mundo." Como vê sua oficina na tarefa de ler o mundo?

D: A oficina lida com a integração de linguagens, portanto já trabalha com várias formas de ler o mundo. Lemos as histórias, conversamos sobre elas e as desdobramos em atividades que vão, geralmente, muito além do texto. A história é apenas um ponto de partida. Com isso, os alunos se apropriam não só das histórias, mas de um universo de significados e de um amplo processo em que eles se envolvem, construindo os objetos e transformando tanto os materiais como a si próprios.

\section{P: Como planeja a experiência da leitura?}

D: $O$ objetivo é estimular a leitura, propiciar o contato com o livro e as descobertas que vêm desse encontro. Os alunos leem individualmente ou em duplas, às vezes conosco, mas não queremos ensinar a ler, não é o nosso papel. Conversamos sobre o mundo a partir da leitura da história. Importante é a troca de ideias; conectar as experiências pessoais dos alunos com o texto lido para produzir algo novo: levar à montagem de uma cena, à confecção de um adereço. Se você não se coloca como artista, você vira apenas mais um professor e não sai do universo do primeiro turno.

P: Como estimular a capacidade de estabelecer analogias entre os vários sistemas de linguagem?

D: Não fazemos uma separação entre os sistemas. O planejamento é baseado na integração das linguagens. Apenas priorizamos as artes visuais no primeiro semestre, porque elas ajudam o aluno a se estruturar em relação a si mesmo, na relação com os materiais e com seu próprio corpo. Isso ajuda as crianças a criarem uma disciplina. Depois, no segundo semestre, buscamos priorizar as artes cênicas, pois aí entram relações mais intensas com o espaço e com o coletivo. No primeiro semestre deste ano, planejamos tratar das histórias relacionadas com o tema da autoestima e, no segundo, o tema era o medo.

P: A leitura é condição de aprendizagem. A ficção é capaz de libertar sonhos e desejos. Qual o papel político ao promover essa possibilidade na construção do leitor aqui no projeto Segundo Turno Cultural?

D: Acreditamos que a contribuição seja a de abrir um espaço para o lúdico e, dentro dele, para a alteridade, como construção de um espaço de respeito. Tudo está ligado ao papel político que se quer privilegiar; daí mediar, focar os desejos das crianças. Nós estamos aqui, por que mesmo? Para possibilitar escuta, para 
ajudar as crianças a se expressarem, a se fazerem entender e a se entenderem entre elas, para que possam se comunicar melhor e possam achar os caminhos para conquistar seus desejos.

P: Somos leitores desde o momento em que abrimos os olhos pela primeira vez. Quando o aluno passa a dominar textos mais complexos, torna-se leitor fluente, competente e crítico. Seu trabalho contribui para formar pontos de vista/leitor, conviver com outro/alteridade ou apenas se propõe a abrir "janelas", livros como forma de conhecimento?

D: Tem a ver com a pergunta anterior, quanto ao espaço de respeito à diversidade. As crianças com que lidamos são inteligentes e extremamente críticas. O que falta muitas vezes é a elaboração dos argumentos, é a clareza, a calma, e a maneira pela qual expressar suas questões de modo a que possam ser ouvidos. Nesse sentido, o projeto contribui, sim. Mas demora... Estamos em Santa Teresa há dois anos e no Vidigal há três. Percebemos que só no terceiro ano os alunos conseguiram se aproximar, confiar. Eles se sentem traídos permanentemente, diariamente. Daí a necessidade de continuidade, e isso demora um tempão. Até a direção se sente traída, pois a cada momento há mudança de projetos, sem participação efetiva dos agentes da escola. Infelizmente, não há conversa no que se refere a essas decisões políticas.

P: A literatura promove autonomia no pensar e no agir do leitor?

D: Depende do olhar de quem faz, depende do leitor se dispor a interagir e refletir. Quando você se permite deixar afetar, a arte "pode" ajudar a refinar a sensibilidade, a se tornar mais humano. Mas não necessariamente isso acontece. Usando a teoria da recepção, a arte, em si, não muda nada. A autonomia é do sujeito. Hitler adorava ópera...

Concluímos brevemente: importante salientar que um espaço arejado, amplo é fundamental para hospedar crianças. Crianças na idade das que lá estudam não conseguem se situar nem situar suas práticas por falta de uma visão orgânica do espaço; os adultos para conseguirem dar conta dessa inadequação do prédio escolar, como no caso dos textos de Clarice, devem ser leitores perspicazes para relacionar tanta informação truncada/fragmentada. Produzir um espetáculo como o que aconteceu no final do ano, é um fato isolado no plano pedagógico do trabalho. Penso que esse prédio deveria ser utilizado para outro fim que não escola.

$\mathrm{Na}$ entrevista com os dinamizadores foi tocada a questão do tempo de existência da oficina no espaço escolar. Leva tempo para conquistar o apoio e a confiança de toda a comunidade; num espaço adequado já é complicado, em um espaço tão limitado, ainda mais complicado. E claro que os dinamizadores também não conseguiram lidar com a mostra em gavetinhas. Não romperam, ou melhor, não puderam contribuir para que a leitura, fora de um momento de 
exceção (o teatro), passasse a fazer parte permanente da experiência dos alunos. O modelo arquitetônico também impediu uma maior integração. 


\title{
4
}

\section{Testemunhando uma Prática de Mediação}

\author{
"O correr da vida embrulha tudo. \\ A vida é assim: esquenta e esfria, \\ aperta e daí afrouxa, \\ sossega e depois desinquieta. \\ O que ela quer da gente é coragem." \\ João Guimarães Rosa
}

Era o ano de 2011: foi um grande desafio aceitar a proposta do projeto das secretarias de Educação e Cultura do município do Rio de Janeiro, denominado Segundo Turno Cultural, para realizar oficinas de literatura em áreas de risco, no início, em duas Escolas do Amanhã situadas na comunidade da Maré.

\section{1 CIEPs Teotônio Vilela e Hélio Smidt}

Conversando com a coordenação do projeto e as duas diretoras das escolas Teotônio Vilela e Ciep Hélio Smidt, ficou acertado que o tema que permearia as leituras do ano em curso estaria ligado ao eixo temático "Cultura afro-brasileira", e construiríamos um labirinto, representando a identidade de cada um, sujeito da cultura brasileira inserida no espaço concreto da Maré.

Julgaram o tema apropriado, justificando como fato real a dificuldade dos alunos ao preencherem um formulário quando a questão em pauta era a cor da pele. A maioria negava a ascendência africana, chegando a trocar ou clarear a cor de sua pele no campo do formulário. Decidido o tema, realizado e aprovado o planejamento, fui para as escolas divulgar a oficina Experiências no Labirinto nas turmas a que julgaram condizente oferecer. As turmas em questão eram as que estavam no quarto ano do Ensino Fundamental. Visitei-as, motivei a participação, fazendo uma espécie de "propaganda" da oficina de leitura, falando da minha experiência/formação e atividades lúdicas que desenvolveríamos juntos. Expus os objetivos, os meios como trabalharia a leitura, e a culminância das atividades seria uma exposição dos trabalhos representando nosso labirinto/identidade, que 
construiríamos durante os 26 encontros distribuídos ao longo do ano. O resultado final seria exposto junto com os outros trabalhos das demais oficinas do Segundo Turno Cultural no teatro Carlos Gomes.

O número máximo para formar um grupo por oficina era de 25 alunos e, quando comecei o trabalho, foi com lotação máxima. Ao longo dos 13 encontros no primeiro semestre, ocorreu mobilidade no grupo: uns logo saíram, outros permaneceram até o fim e 10 alunos foram se revezando (outros alunos entraram nos lugares vagos). A média de presença foi em torno de 15 participantes durante os 26 encontros anuais. Um aspecto importante que justifica a mobilidade no grupo era a oferta de outras atividades paralelas, na comunidade da Maré, num circo perto da Escola Teotônio Vilela, e no Ciep Hélio Smidt, outras oficinas esportivas. Eles revezavam, ora na oficina de leitura, ora nas atividades físicas. Felizmente havia os cativos ou cativados, mas foi um eterno desafio. Por um lado é interessante não haver obrigatoriedade de presença, pois é uma superação constante no sentido de rever minuciosamente todas as atividades planejadas, mas por outro, aqueles que frequentaram assiduamente, acabaram avançando num ritmo menor, pois era preciso retomar o início da atividade toda vez que um grupo novo entrava na turma.

Sem dúvida, estabelecer parceria com a escola é fundamental, mas nem sempre se consegue. Talvez pela oficina ocorrer uma vez por semana e, com isso, ser difícil encontrar professores, direção ou orientador pedagógico; ou talvez quem sabe, a superlotação de atividades oferecidas para as Escolas do Amanhã sem o envolvimento direto dos docentes, equipe pedagógica e direção - o fato é que há pouca integração entre o educacional e o cultural.

$\mathrm{Na}$ escola Teotônio Vilela, que não é de tempo integral e funciona com dois turnos, a oficina iniciava às 11 horas e 30 minutos. Alguns alunos eram do turno da manhã e permaneciam por mais duas horas na escola; outros vinham uma hora antes de iniciar o turno escolar da parte da tarde. A média de presença de alunos era maior nessa escola. Já no Ciep Hélio Smidt, escola de tempo integral, o contraturno funcionava ao final das atividades do dia, por volta das 14 horas. As presenças oscilavam, era bem instável, foi difícil avançar com as propostas, pois acabava acontecendo uma desconexão com o planejamento, interferindo na sequência e profundidade da leitura. Logo, não permaneci na Hélio Smidt no segundo semestre, julgaram inadequada a proposta para aquele espaço. A oficina 
do Segundo Turno Cultural, que lá permaneceu no segundo semestre de 2011 até final de 2012, foi a de canto coral. Não conseguimos solidificar nossas relações de leitura nem as pessoais, no entanto, a atividade cultural de canto foi aceita e conseguiu realizar seu planejamento com resultado satisfatório.

A prestação de contas do trabalho realizado no mês consiste em entregar a lista de presença na secretaria de Cultura e, para a escola, o planejamento no início do trabalho e no final do semestre. Sou avaliada, portanto, pela escola na qual trabalhei. Faço um relatório considerando planejamento e execução. Quando ocorre algum problema nas atividades, após conversa com a escola, passamos o ocorrido para a coordenação do projeto na secretaria de Cultura.

O objetivo geral da oficina era contribuir para a formação de novos leitores, conscientizando-os sobre o papel da cultura africana na formação da subjetividade, além de relacioná-la com a formação da cultura brasileira. As atividades na Teotônio Vilela ocorriam geralmente na sala de leitura ou em alguma sala que estivesse vazia. Já no Ciep Hélio Smidt, eram nas salas que estavam desocupadas, ou seja, não havia um espaço fixo, salas itinerantes e algumas vezes alagadas. Cheguei a trabalhar no corredor. Essa escola estava com diretora de licença no início do ano, foi substituída por uma professora, que retornou para a sala de aula depois do regresso da diretora. Ao final do semestre, a professora que substituíra a direção, foi para o cargo de orientadora pedagógica. A situação administrativa era bem complicada.

As estratégias utilizadas para a promoção e aproximação da leitura textual eram as mais variadas, e o aspecto lúdico estava presente em todas elas. A idade das crianças era em torno de 10 a 12 anos. Criamos um diário de bordo, uma pasta contendo todas as atividades realizadas, que ao final do semestre levariam para casa. Funcionou como um arquivo do percurso realizado ao longo dos 13 encontros e serviu para a avaliação que realizamos no último dia do semestre, antes do recesso do meio do ano.

Iniciamos nossos trabalhos com a poesia de Pedro Bandeira, cujo título era Identidade. Preenchemos um formulário de apresentação com dados pessoais, apontando gostos, traços de sua personalidade e familiar, atividade de lazer preferida, seus sonhos e tristezas etc. Em seguida, o formulário era lido pelo colega que estava sentado ao lado na roda formada. Depois, ouviram a lenda grega 
O Minotauro, e fizemos uma dinâmica com barbante para vivenciarmos o labirinto da história.

Assistimos ao desenho animado francês Kiriku e a Feiticeira, que se passava na África, cujo personagem principal Kiriku, um menino bem pequeno e rejeitado pelos demais, procurava matar o Minotauro, na história a feiticeira Karabá. Devido a um trauma (espinho cravado nas costas), ela vinha dizimando os homens da tribo de Kiriku. Ele enfrenta a feiticeira, entra num "labirinto" para encontrar o sábio que ensinaria como desfazer o feitiço para os homens da tribo retornarem para suas famílias.

Organizei uma ficha de observação sobre o filme, relacionando-o com as histórias de Teseu e Ariadne, da mitologia, as diferenças e semelhanças entre os dois textos, enredo, personagens, escolha do traçado do desenho (comparando com os da Disney que está na TV), enfim, para discutir os aspectos da cultura africana ali apresentados.

Num segundo momento, partimos para o continente africano, brincando de safári virtual na sala de informática, através de dicas/fio de Ariadne, para conhecer um pouco do continente africano. Vimos no mapa de quais países vieram os escravos para o Brasil, onde aportaram no continente americano. Também analisamos o globo terrestre, especialmente a África com seus 53 países, pelo site Google maps.

Utilizando o site Smartkids, brincamos com os bichos mais conhecidos que fizeram parte do safári virtual, com caça palavras, localização dos animais no mapa, após a leitura de texto selecionado na internet. No Google imagem, vimos o relevo africano: savana, serengueti, deserto, floresta tropical africana e fotos de tribos, costumes e peculiaridades. Esse bloco da oficina terminou com uma pequena carta escrita para uma criança africana, dando informações sobre o local onde moravam no Brasil. A carta era endereçada a uma criança de um determinado país africano que era pintado no mapa (escrita coletiva). $\mathrm{O}$ aspecto da leitura ficou centrado em textos informativos retirados da internet.

Utilizando o Google maps, chegamos até a escola onde eles estavam localizados no momento. Passeamos virtualmente pelo Rio de Janeiro e chegamos até a Maré. Fomos para o papel desenhar como chegariam até suas casas, o trajeto que costumavam fazer da escola para casa, construindo um mapa. Perceberam que 
a cidade onde moravam, era um labirinto de ruas e que a palavra labirinto é polissêmica.

O terceiro momento foi centrado no homem. Utilizei a questão da máscara na construção da identidade na cultura africana: a manufatura e uso de máscaras nos rituais das tribos do continente, processo de purificação, com reza aos espíritos ancestrais, procedimento ritualístico que entrou em declínio nas últimas décadas. Entretanto, o emprego desses objetos continua sendo um aspecto fundamental na identidade de vários grupos étnicos africanos ainda hoje. Por isso, já existem pessoas que trabalham pela preservação desse hábito milenar. No ocidente, a utilização de máscaras está ligada ao teatro grego e oriental. É ainda utilizada em rituais nas tribos indígenas como transfiguração, disfarce, símbolo de identificação. Nos dias de hoje, está presente nos festejos de carnaval como adereço.

Os textos que lemos sobre esse assunto foram instigantes e informativos. Seguimos para a criação de máscaras, primeiro com maquiagem, uns maquiando os outros. Depois confeccionamos em papel cartão máscaras com as cores africanas (preto, vermelho, verde e amarelo) para serem expostas no labirinto. Fechando esse módulo, aluguei roupas africanas, e eles se vestiram de africanos e pousaram para fotos, primeiro de uniforme e depois com a fantasia. As fotos foram para as paredes do labirinto na mostra que aconteceu em outubro de 2011.

Passamos para a parte seguinte que denominei memória da língua: as palavras de origem africanas que entraram para o português, vindas da África. Construímos um pequeno glossário e depois brincamos de jogo da memória. Tratamos do início da escrita, os hieróglifos egípcios, que são um primeiro alfabeto. Cada um desenhou a letra de seu nome conforme a escrita daquela época. Todos os trabalhos eram recolhidos para depois fazerem parte da pasta individual que cada um levou para casa.

Outro aspecto abordado foi o musical: as influências africanas no ritmo musical brasileiro, os instrumentos de percussão e danças. Trabalhamos letra e música de Mama África de Chico César, Dandalunda de Margareth Menezes, entre outras. A oficina seguinte foi construir com objetos reciclados (pneu de bicicleta, cabo de vassoura, bombona, latas de Nescau e latas menores), instrumentos de percussão. Esse trabalho foi realizado por uma especialista em ritmos africanos, Clarete Braz Patrocínio, que trabalha com percussão e confecção 
de instrumentos no quilombola localizado em Quatis e em comunidades carentes no interior do estado do Rio. Os alunos fizeram os instrumentos e aprenderam duas batidas tipicamente africanas.

O livro lido no semestre foi A África meu pequeno Chaka..., de Marie Sellier, com ilustração sensível de Marion Lesage alternada com a reprodução de objetos tradicionais da África como instrumentos de música e estatuetas. O texto mais as ilustrações somadas à cor transmitem um olhar especialmente mágico sobre o continente africano.

Chaka logo percebe que vovô Dembo, com sua imaginação entre o plausível e o mágico, faz um retrato em que se sobrepõem duas histórias, a dele mesmo e a do continente mais antigo e mais pobre do planeta. A África, meu pequeno Chaka... reata com a tradição africana do contador de histórias, figura central de um mundo sem livros e sem escolas, e a quem cabe transmitir a saga da família, da aldeia, de seu povo, fundindo a memória pessoal com a coletiva ${ }^{14}$.

Conversamos sobre o aspecto da oralidade tão marcante na cultura africana. O narrador da história era o vovô Dembo que contava para o pequeno Chaka, seu neto, como era sua aldeia, o que fazia durante o dia, o festim de rei, os antepassados, as aventuras com o melhor amigo Lawali-travesso etc. A estrutura do texto, apesar de escrito, nos remete à oralidade, característica tipicamente do continente africano. A atividade que desenvolvemos a seguir foi fazer uma pequena entrevista com a pessoa mais velha da família, de preferência o avô ou avó, aos moldes do livro. Levaram uma sugestão de entrevista para casa e, no encontro seguinte, compartilharíamos as histórias dos familiares que compõem a identidade de cada um. Somente um aluno realizou a tarefa. Felizmente há os que gostam da escrita e entendem o valor do registro. Atribuo à não execução da tarefa pelos alunos a dificuldade de escrita, tarefa para casa em atividade extra escolar não é muito bem vinda, e também à motivação, pois quando lemos em voz alta, não havia um exemplar por dupla. A atividade deixou a desejar que me levou a rever o tipo de texto e o número de livros por aluno quando a atividade de leitura fosse em voz alta, pela necessidade de todos acompanharem a leitura do texto sem dispersão.

\footnotetext{
${ }^{14} \mathrm{http}: / / \mathrm{www}$. companhiadasletras.com.br/detalhe.php?codigo=40394.
} 
A única atividade que realizamos fora da escola foi uma visita à biblioteca Parque de Maguinhos, no dia 15 de junho de 2011, previamente agendada com as diretoras e o local a ser visitado. No entanto, uma semana antes não haviam confirmado ônibus. Enriqueceria a oficina fazermos visitas a museus, mostras, shows adequados à faixa etária do grupo, mas é confusa a liberação do transporte para passeios que é da competência da Coordenadoria Regional de Educação (CRE).

Terminamos o semestre com um jogo da memória com perguntas envolvendo todas as atividades realizadas no semestre, e o grupo que conseguisse maior número de pontos ganharia um pacote de pirulitos. No entanto, antes de entregar os pirulitos para o grupo vencedor, li uma história da jornalista e filósofa Lia Diskin que contou um caso de uma tribo na África chamada Ubuntu no festival Mundial da Paz, em Florianópolis, em 2006, onde as crianças, numa brincadeira de competição inofensiva, ao ganhar as guloseimas dividiram com as que perderam para que todos ficassem alegres. Não era possível naquela tribo comer, vendo o outro triste.

Finalização do semestre: assistimos ao vídeo com imagens colhidas nas atividades, entregamos as pastas e fizemos a avaliação das atividades oralmente.

Relatando o planejamento, vendo o encadeamento sequencial para inserilos na cultura afro-brasileira, fico pensando no "papel cabe tudo". Os ruídos de comunicação, as ausências, o mau funcionamento do som no desenho animado, computadores com problema, a dificuldade para abrir os armários, trancados por causa dos constantes roubos, as "paredes à Niemeyer" que vazam todo o som, numa oficina lúdica na qual as crianças cantam, riem e se movimentam. A falta de material escolar para os mapas, máscaras, a agitação quando havia tiroteio na área. Foram muitas as interferências.

No ensaio, "Língua que não sabemos que sabíamos", apresentado numa conferência em Estocolmo em 2008, publicado no livro $\underline{E}$ se Obama fosse africano?, Mia Couto aponta para uma questão que está sempre presente em minha mente e em minha prática como mediadora/professora: será que aquilo que trago faz sentido para aquele que me ouve, para quem realizo planejamento e pesquisa? Será que conseguimos nos comunicar em nossa língua que a princípio é a mesma, mas que é de uma riqueza polissêmica que muitas vezes não alcanço as sutilezas do significado? Na realidade, para qualquer projeto/programa acontecer, 
é preciso ter em mente o interlocutor/aluno/cidadão. Traçamos um planejamento, mas que vai se configurando à medida que vamos colocando em prática. No ensaio em questão, Mia Couto aponta de forma irônica sua experiência como tradutor do inglês para o português: Dito de outro modo, todos nós somos impossíveis tradutores de sonhos. Na verdade, os sonhos falam em nós o que nenhuma palavra sabe dizer. (p.12)

Vivemos dominados por uma percepção redutora e utilitária que converte os idiomas num assunto técnico da competência dos linguistas. Contudo, as línguas que sabemos - e mesmo as que não sabemos que sabíamos - são múltiplas e nem sempre capturáveis pela lógica racionalista que domina o nosso consciente. Existe algo que escapa à norma e aos códigos. (Couto, 2009, p.14)

Mia Conto conta, nessa Conferência Internacional de Literatura Waltic, um episódio que aconteceu em 1989 na Ilha da Inhaca, numa visita de técnicos das Nações Unidas para educação ambiental (grifo do autor). Traziam slides, projetores, filmes, mas isto não os salvou dos problemas de entendimento e de comunicação que ocorreram, pois Mia Couto traduzia do inglês para o português, e o pescador traduzia para seu idioma chindindinhe. Existem mais de 25 línguas distintas em Moçambique e logo na apresentação ocorreu uma sucessão de ruídos na comunicação para entendimento da proposta trazida pelos técnicos. Retiro um trecho que exemplifica o que muitas vezes penso acontecer com tantos projetos que têm sido encaminhados para as escolas públicas, não só às Escolas do Amanhã:

$\mathrm{Na}$ primeira reunião com a população surgiram curiosos mal-entendidos que revelam a dificuldade de tradução não das palavras, mas de pensamento. No pódio estavam os cientistas que falavam inglês, eu, que traduzia para o português, e um pescador que traduzia de português para língua local, chindindinhe. Tudo começou logo na apresentação dos visitantes (devo dizer que, por acaso, a maior parte deles eram suecos). "Somos cientistas", disseram eles. Contudo, a palavra "cientista" não existe na língua local. O termo escolhido pelo tradutor foi inguetlha que quer dizer feiticeiro. (Couto, 2009, p.17)

O que esperamos de nossos planejamentos, programas e projetos? Eles só fazem sentido a partir do grupo, tendo em mente que não viemos "salvar" alunos da escuridão dos índices das Escolas do Amanhã, como algumas propostas de 
governos nos fazem acreditar. Nossa "tecnologia" e "latim" só farão sentido no momento em que nos abrirmos para a troca. Temos leitura/literatura para oferecer, mas a leitura só existirá a partir da anuência do leitor. Só existe texto, se houver leitor. Os cientistas que se propuseram a uma “educação ambiental”, dizendo: Não quero comentar aqui como esse conceito de educação ambiental esconde muitas vezes uma arrogância messiânica (p.16), só entenderão os problemas ambientais que perturbam a ilha se perceberem o entorno, os interlocutores, disse o ficcionista moçambicano. Para tal devemos estar aberto.

\section{2}

\section{CIEPs Chanceler Willy Brandt e Coronel Sarmento}

No segundo semestre de 2011, houve mudança de escola, saiu o Ciep Hélio Smidt e entraram o Ciep Chanceler Willy Brandt (comunidade do Jacaré) e o Ciep Coronel Sarmento (comunidade do Alemão), continuando com o grupo da Teotônio Vilela (comunidade da Maré) do primeiro semestre. Convidei uma colega do mestrado em literatura da PUC-Rio para trabalharmos juntas, agora eu teria três grupos, demanda maior. $\mathrm{O}$ tema - identidade cultural brasileira a partir da influência africana - continuou, mas nessas duas escolas que começamos do zero, acrescentamos o aspecto de outras culturas que migraram para o Brasil e que compõem nossa identidade híbrida.

De acordo com Canclini, 1989,

Falar de fusões não nos deve fazer descuidar do que resiste ou se cinde. A teoria da hibridação tem que levar em conta os movimentos que a rejeitam. Não provêm somente dos fundamentalismos que se opõem ao sincretismo religioso e à mestiçagem intercultural. Existem resistências a aceitar estas e outras formas de hibridação porque geram insegurança nas culturas e conspiram contra a autoestima etnocêntrica. Também é desafiador para o pensamento moderno de tipo analítico, acostumado a separar binariamente o civilizado do selvagem, o nacional do estrangeiro, o anglo do latino. (Canclini, 1989: XXXII-XXXIII)

Os processos de hibridação, apropriação de elementos de várias culturas, não implicam que as aceitemos indiscriminadamente. De todo modo, a intensificação da interculturalidade favorece intercâmbios, misturas maiores e mais diversificadas. A composição do povo brasileiro de língua portuguesa tem 
sua identidade entrecruzada, porosa para as invasões estrangeiras. Logicamente que não tratamos na oficina da questão filosófica, econômica que permeia a composição de nossa identidade. Ficamos na constatação do aspecto multicultural da formação da gente brasileira.

A colaboração e parceria de uma colega foi muito importante para a execução dos trabalhos: reestruturar o planejamento da oficina, ter em conta a demanda/tempo que ficaríamos com os grupos novos, considerando que o segundo semestre é sempre mais complicado para se trabalhar, porque é época das provas que são aplicadas nas Escolas do Amanhã, fora a questão do reforço escolar. Às vezes ficávamos com uma lacuna de mais de quinze dias para realizar a oficina, o que certamente prejudicava o andamento/conexão com as leituras. Iniciar algo, quando os horários e rotinas já estavam estabelecidos nessas escolas novas, demandou muitos ajustes.

Em conformidade com Yunes, 2009, que aborda três perspectivas para que o ato da leitura aconteça, compreendemos que

Toda leitura se estabelece pelo menos sob três perspectivas: a da percepção inicial do texto, descompromissada, mas interessada que repara no vocabulário, na sua estruturação, no ritmo e nas sonoridades, na mensagem (!); a da interpretação intelectual, que não se dá isoladamente, como de uma forma original, mas se estabelece necessariamente em diálogo com outras interpretações cabíveis em uma cadeia de leituras, que não se referem mais ao enunciado (o que foi dito), mas às enunciações (o modo e as condições de emissão desse dizer); a da recepção afetiva, em que se deixando afetar pelo outro, o leitor se vê em busca de um sentido para o convívio. A letra precisa tomar corpo e saltar para a vida, para a partilha efetiva do sentido. Essas modalidades não se excluem, ao contrário, completam-se na realização da leitura. (Yunes, 2009, p.45)

Estabelecer as três perspectivas elencadas por Yunes, no meio do ano, com provas, feriados, conselhos de classe, dia de estudo, foi um enorme desafio. Além das avaliações bimestrais, os alunos das Escolas do Amanhã fazem Prova Brasil, Provinha Rio e Rio Alfabetiza, todas no segundo semestre, que são testes indicadores de avanço na escolarização.

Na comunidade do Alemão, a oficina acontecia após o horário do jantar (os alunos fazem três refeições na escola e a última denominam jantar, apesar do horário, 13 horas e 30 minutos). Esse horário é complicado porque a dispersão e o cansaço são maiores. Na comunidade do Alemão, foi escolhida pela diretora a turma do quarto ano, com faixa etária semelhante a das crianças das outras 
escolas. A professora tornou-se parceira, encaminhava os alunos, via a frequência, e trocávamos impressões. Não conseguimos criar laços com os meninos e nem estabelecer intertextualidade; foi um período com muitas interrupções; não conseguimos realizar as 13 oficinas previstas; tivemos 11 encontros no total durante o semestre.

O planejamento básico do semestre foi o seguinte:

1. Definição do termo migração retirado dos dicionários da Língua Portuguesa de Antônio Houaiss e Aurélio Buarque de Hollanda, uma definição sociológica e outra econômica, e os alunos depois de lerem e discutirem, escreveram o que entenderam sobre o termo;

2. Assistiram a um curta retirado do Youtube, "Borboletas Menarca", sobre seu processo migratório, constatando que os animais também migram;

3. Assistiram ao filme Smurfs que migraram para Nova Iorque. Preencheram uma ficha de observação do filme, e discutimos a questão central na formação de nossa identidade que foi a questão da migração e como ela ocorre no filme;

4. Em seguida, fizemos uma retrospectiva da história humana em relação à trajetória do povoamento e correntes migratórias da Terra. Utilizamos mapas, poesia de Carlos Drummond - Os homens, as viagens - e música - Encontros e despedidas, composição de Milton Nascimento e Fernando Brandt na voz de Maria Rita. Conheciam a letra por ter sido tema de novela;

5. Leitura do livro de Marina Colassanti, Era uma vez Dom Quixote, adaptado por Agustín Sánchez Aguilar, baseada na obra clássica de Miguel de Cervantes, Dom Quixote, para tratar da migração espanhola;

6. Produção de personagens em isopor para focarmos naqueles que mais chamaram atenção. Aspecto cômico.

A primeira migração recebida no Brasil foi a dos portugueses que encontraram o povo primitivo que aqui habitava, os índios. Destacamos o aspecto da dificuldade de comunicação linguística, preparamos um texto sobre linguagem verbal e não-verbal, como se deu a comunicação entre eles. Brincamos de recorte e colagem sobre as linguagens. 
Abordamos a vinda da família real e a questão da língua portuguesa como língua oficial. Fizemos um quadro comparativo em que constavam números de falantes da língua portuguesa que estavam distribuídos pelos seguintes países: Moçambique, Angola, Portugal, Guiné-Bissau, Cabo Verde, Timor Leste, São Tomé Príncipe, Macau e, por fim, o Brasil. Fomos para o mapa, localizamos todos os países. A brincadeira ficou por conta das tirinhas que leram sobre a descaracterização dos povos primitivos, piadas sobre a comunicação entre os índios e os portugueses.

Entramos com a migração africana, ou seja, os países que vieram para o Brasil (República do Mali, República do Congo, República de Gana, República de Angola, República de Moçambique, Guiné e Nigéria). Novamente utilizamos a leitura de mapa e refletimos sobre sua trajetória. A parte lúdica ficou a cargo do símbolo não-verbal referente às bandeiras desses países. Pintamos bandeiras e as confeccionamos com massa comestível, como docinho de festa nas cores africanas. Ao final, comeram suas bandeiras e levamos algumas para a direção da escola. Foi a verdadeira festa antropofágica.

A leitura literária do semestre ficou a cargo da tradução de Marina Colassanti, Era uma vez Dom Quixote, adaptada por Agustín Sánchez Aguilar baseada na obra clássica de Miguel de Cervantes, Dom Quixote. Tratamos da migração espanhola e suas influências no continente como um todo. A leitura da obra foi feita em conjunto e, dessa vez, havia um número maior de exemplares, conseguindo que participassem e se interessassem mais pela leitura da obra; fato que não ocorreu no primeiro semestre. Finalizamos a leitura com um trabalho de “isoporgravura" dos personagens principais.

Pretendíamos abordar as outras migrações: japonesa, italiana, alemã, dos povos do Oriente Médio e dos EUA, mas a questão dos feriados, provas, conselhos de classe etc. foi interferindo nas conexões, e não concluímos o planejado, embora nas escolas Teotônio Vilela e Coronel Sarmento, tivéssemos conseguido realizar uma boa parte do planejamento inicial.

O grupo que continuou no segundo semestre da comunidade da Maré apresentou uma melhora significativa no comportamento e no entrosamento com as leituras (trabalhos de intertextualidade), fizeram as ligações com propriedade. No entanto, houve decréscimo no número dos participantes que atribuo ao Mais Educação (as crianças que faziam parte da oficina, mas que estavam com baixo 
rendimento escolar saíram, ou as mães os puniram, tirando-os de uma atividade que gostavam). Outra questão foram as lacunas entre os encontros, provas, feriados, conselhos etc. Quanto à escola Coronel Sarmento, a leitura do livro Era uma vez Dom Quixote não foi realizada. Como a oficina acontecia após o “jantar”, além de toda complicação com provas e feriados, precisei de mais tempo para o entrosamento e tive dificuldade com disciplina, apesar de ter o apoio da professora e conversarmos sobre alguns alunos que tinham muita dificuldade de concentração. O trabalho ficou incompleto, mesmo tentando seguir as orientações de Heloísa Buarque de Hollanda em texto escrito para a discussão do Plano Estadual do Livro e Leitura,

(...) o melhor é como diria Oswald de Andrade "ver com olhos livres". O que eu, pessoalmente traduzo como: suspenda seus juízos de valor, pense o mínimo que conseguir e apenas observe o momento com atenção flutuante e um ouvido tamanho máximo ${ }^{15}$.

Não realizamos a leitura de um texto literário, importante para a proposta da oficina.

Já no CIEP Chanceler Willy Brandt, foi atípico em tudo. Refizemos três vezes o planejamento após os primeiros encontros com o grupo. Assim como no Ciep Coronel Sarmento, não fizemos propaganda da oficina. Foi-nos dado um grupo de 15 alunos de faixa etária diversa, semi-analfabetos, sem nenhuma motivação ou abertura para um trabalho lúdico com leitura. Era a classe do "acelera": teriam que concluir o primeiro segmento do Ensino Fundamental devido à distorção série/idade. Não fosse a professora ter abraçado o projeto, e se disposto a refletir e dar continuidade em seu turno normal às atividades que fizemos, nada teríamos conseguido. A oficina acontecia às quartas-feiras e, apesar de ser seu dia de folga, a professora estava presente durante a oficina, além de nos acompanhar nos passeios.

Primeiro a "migração" teve que acontecer na prática, ou seja, migrar do espaço escolar para espaços culturais na cidade. Não havia referência familiar, raiz migratória. Não sabiam, ou não queriam saber, de onde vieram os avós, se

\footnotetext{
${ }^{15}$ Disponível em <http://www.cultura.rj.gov.br/secao2/doc/gps_livro_e_leitura_final_heloisa_buarque_de_hollanda_1354734412.pdf>. Acessado em 04/02/2013
} 
tinham ascendência africana, indígena ou européia; soltos, apáticos, sem brilho nos olhos.

Mensalmente passeávamos. Primeiro fomos ao Planetário, viajar pelas galáxias, depois ao museu Aeroespacial, a um espetáculo no teatro Carlos Gomes e, por último, à Ilha Fiscal. Logicamente, a questão textual ficou para segundo plano, focamos a leitura de mundo. Como a professora esteve conosco todo o tempo, soubemos que o conteúdo não avançou muito, mas a frequência escolar mudou. Aos encontros semanais, não faltavam, presença maciça, e lentamente foram começando a interagir nas atividades e nos passeios, até formarem um grupo com um rosto refletindo sinais de vida e com certa alegria. Não conseguimos que se integrassem à escola, eram excluídos e totalmente indiferentes aos resultados pedagógicos. Repetir de série, ir adiante, ficar no mesmo lugar representava a mesma coisa. A posição do corpo era largada, cabeça baixa e muitas vezes olhos fechados. Entretanto, não findamos o ano assim. A leitura de mundo vivida trouxe resultado que surpreendeu a todas nós.

Ano novo, vida nova? As escolas permaneceram as mesmas, mas a oficineira havia mudado. Fazendo uma reflexão sobre as diversas realidades das três escolas, comecei minha proposta para 2012 nomeando as atividades de Literatura em Rede. A questão de não conseguir um exemplar por aluno para leitura, levou-me aos contos, às poesias e à web. Dava para fazer uma seleção de textos, ou troca-troca de livros, enfim, o texto literário circularia mais do que no ano anterior. Essa foi a primeira decisão para pensar sobre o planejamento dos 26 encontros anuais. Já conhecia os espaços, as dificuldades e os limites que encontraria.

Quando levei a proposta de trabalho para a apreciação das diretoras, falei da minha intenção de usar mais a sala de informática e que privilegiaria a escritora e ilustradora Angela Lago e, como seu processo criativo estava ligado ao computador, concluiríamos nossas atividades escrevendo um e-book com textos narrativos e/ou poesias feito pelos alunos. Acharam interessante a possibilidade de conexão leitura/internet, utilizar o suporte digital, espaço virtual tridimensional com novas perspectivas, novas maneiras de olhar o mundo tão familiar para esta geração de leitores e futuros escritores/ilustradores, pareceu-lhes uma boa abordagem. Um mundo não linear, dinâmico que faz parte/sentido para os novos membros da minha oficina, seria um caminho. 


\begin{abstract}
"Uma criação transmídia, por sua vez, lança mão simultaneamente de vários suportes e metodologias de criação (por exemplo do design, do vídeo, da animação, da literatura) para criar novos formatos de expressão que não se identificam especificamente com nenhuma das mídias que constituem seu DNA. Uma criação transmídia define novas linguagens muitas vezes ainda não codificadas. (...) Os jovens poetas hospedados na web já começam a anunciar novas práticas da palavra-movimento, palavra-som, palavra-imagem, da palavragame. (...) Parece mesmo que outra forma de arte da palavra está surgindo no nosso horizonte. A essas novas praticas, podemos chamar de (ou pensar como) palavra expandida.". (Secretaria de Estado de Cultura Plano Estadual de Cultura Documento Setorial de Livro e Leitura - texto escrito por José Marques Castilho Neto $)^{16}$
\end{abstract}

A ideia do e-book está associada ao impacto das novas tecnologias digitais na produção e consumo culturais, bem como às perspectivas abertas pelo ambiente da internet para criação e para democratização do acesso ao conhecimento. É um espaço de interesse dos alunos para leitura e trocas de informações, além de ser veículo de comunicação estimulado pela lógica participativa.

Após a aprovação da direção, fui para as turmas indicadas para divulgar a proposta da oficina que acabei nomeando de Literatura em rede. Contei brevemente sobre o trabalho executado no ano anterior que ficou centrado no aspecto labiríntico da formação da identidade brasileira, considerando especialmente as contribuições africanas para nossa cultura. Contei sobre a exposição dos trabalhos do Segundo Turno Cultural, mostra no teatro Carlos Gomes em outubro de 2011, aproveitando para explicar a proposta do projeto como um todo que é de possibilitar, experienciar as diversas formas culturais no espaço escolar.

A oficina Literatura em Rede estava propondo o tema da leitura literária cujas regras podem ser subvertidas, em que nada é absoluto, pois o leitor vai construindo e reconstruindo sua leitura como um processo ativo, e os significados se estabelecem a partir da experiência de fruição, ou seja, alguma relação de prazer a partir do contato com os textos, sejam eles digitais ou em livros convencionais.

\footnotetext{
${ }^{16}$ Disponível em <http://www.cultura.rj.gov.br/secao2/doc/gps_livro_e_leitura_dinal_jose_castilho_1354734353.p df>. Acessado em 04/02/2013.
} 
Propus que lêssemos textos informativos, literários, assistíssemos a filme(s); trabalharíamos com ilustração (cores, traçados, formatos), um jogo textual no qual tanto a linguagem gráfica quanto a escrita seriam utilizadas de forma pouco convencional. A escritora Angela Lago foi a autora privilegiada em nossa leitura no ano de 2012, leríamos outros autores, mas o foco seria nessa mineira, que foi objeto de tese de André Mendes, vencedor do Prêmio Moinho Santista Juventude - 2002 e que se encantou pela forma como a autora trabalha com texto e imagem de uma maneira complexa e desafiadora.

\footnotetext{
"Descobri uma ilustradora que não se contentava em pensar a imagem gráfica como uma representação explicativa do texto; ao contrário, fazia questão de ir além do texto original, produzindo imagens complexas que não apenas agregavam um valor estético, como ampliavam as possibilidades de leitura dessas obras, enriquecendo-as como objeto artístico.” (Mendes, 2007, p. 13)
}

A proposta de 2012 seria leitura na web associada a livros de contos, poesias e alguns títulos da extensa obra de Angela Lago. A faixa etária das crianças era de 9 a 11 anos, alunos do $3^{\circ}$ ao $5^{\circ}$ ano (maioria) do primeiro segmento do Ensino Fundamental. Cada diretora deu um encaminhamento para meu projeto, e comentarei sua execução por escola, porque as características dos grupos são diferentes entre si.

\subsection{1 \\ Comunidade da Maré}

Começarei pela escola que trabalha com dois turnos, Escola Municipal Teotônio Vilela da comunidade da Maré, cujo horário de funcionamento da oficina fica entre os dois turnos. O grupo foi composto por alunos da parte da manhã (em menor número) e alunos do turno da tarde. Atribuo ao cansaço os da manhã não se sentirem tão motivados para participar, já ficaram um bom tempo na escola; enquanto que os da tarde entravam mais cedo, ainda estavam descansados. Eram duas professoras que trabalharam no $4^{\circ}$ ano, com duas turmas cada.

Iniciamos nossa oficina em abril com 30 alunos e finalizamos em novembro com 15. As atividades aconteciam na sala de leitura, "espaço 
multimidiático" que também funcionava como sala de informática. Não havia um responsável específico pela sala de leitura: eram três professores que completavam sua carga horária naquele espaço. No ano anterior foi diferente, o bibliotecário foi meu parceiro, inclusive nas duas saídas que realizamos em 2011 (junho - biblioteca Parque de Manguinhos e outubro - Mostra de trabalhos do Segundo Turno Cultural no teatro Carlos Gomes).

A pesquisadora Lêda Fonseca, ressalta o papel da sala de leitura para as atividades de incentivo à leitura:

O papel da Sala de Leitura era ressaltado no sentido de criar atrações para que os alunos buscassem a leitura. Eram sugeridos eventos culturais relacionados à produção e à leitura de textos, tais como: palestras sobre livros, autores e estilos literários, lançamento de livros infanto-juvenis, apresentação de contadores de histórias populares, concursos de poesias, textos em prosa, exposição de cordel, livros artesanais, textos de alunos e professores etc. (Fonseca, 2004, p.42)

Realizar a oficina numa sala de leitura é especialmente interessante por toda essa aura, ter nas prateleiras livros que muitas vezes lançamos mão. No entanto, as pessoas que estavam envolvidas com o espaço, não exerciam a função pedagógica de fomentador de leitura, nem de bibliotecários, pois não conheciam o acervo e nem gerenciavam os recursos das mídias educacionais existentes na sala de leitura. Não houve a parceria que foi tão proveitosa em 2011. Felizmente, havia um técnico na sala de informática, que auxiliou nas atividades de pesquisa, leitura, ilustração e confecção do e-book.

Avançamos como parceiros, a relação com todos na escola foi amistosa e mais próxima, pois eu entendia perfeitamente os mecanismos de funcionamento de todo o espaço escolar, conhecia melhor alguns professores, o antigo responsável pela sala de leitura/multimeios agora era diretor adjunto e consegui contornar melhor a quantidade de provas do segundo semestre, sem tanta interferência no meu trabalho. Entramos num acordo para reposição em outros dias sem grandes problemas.

Apesar de ter participado da Feira de Literatura na Teotônio Vilela, ocorrida no primeiro semestre, expondo os trabalhos realizados na oficina de 2011, não consegui adesão e parceria das professoras das turmas que compunham o grupo em 2012, e também não houve possibilidade dos alunos que frequentaram o ano de 2011, entrassem no grupo de 2012. A diretora não abriu essa 
possibilidade, mas ao terminar o ano de 2012, já combinamos que em 2013, os antigos participantes terão prioridade nas vagas e abriremos novas vagas para outros interessados. Ou seja, haverá continuidade e, quem sabe, permanência do trabalho, fundamental para mensurar os avanços interpretativos, as conexões intertextuais e a expansão de repertórios.

O planejamento da oficina Literatura em rede do primeiro semestre de 2012 foi o seguinte:

1. Contação do conto folclórico oriental A semente da verdade, seguida de apresentação do grupo/dinâmica da colcha de retalhos. Exposição do projeto e metodologia a ser aplicada. Importância dos contos, causos, narrativas ancestrais conhecidas de todos como memória coletiva, um patrimônio da humanidade e uma importante trilha para compreender a vida interior.

Eu conto porque creio nas palavras. Creio na sua amorosa substância. Creio que, como os gestos - é ela outra coisa mais ou menos do que um gesto - , a minha cria laços. Eu, que me dou quando confesso minha vida, uma fração silenciada antes dela, enlaço o outro. Trago-o para mim. Não apenas eu nunca mais serei o mesmo, porque narrei a ele, mas ele também. Ele nunca mais será o mesmo (...). Agora somos. (Carlos Rodrigues Brandão)

2. Leitura de poesias de diversos poetas e atividade lúdica em grupos com as poesias separadas em partes para montarem um quebra-cabeça e os alunos lerem em voz alta;

3. Conhecendo a autora da qual leremos mais obras: vídeo de uma entrevista em que a escritora e ilustradora Angela Lago dá a um programa de literatura sobre seu processo de criação ligado ao computador, ligação entre a imagem e a palavra. Levei alguns livros da escritora e os alunos folhearam as obras. Observação do processo criativo do livro de Angela Lago Cânticos dos cânticos, sua construção, o aspecto labiríntico da ilustração podendo inverter a leitura (início e fim);

4. Retomamos o processo criativo de Angela Lago e lemos o livro da

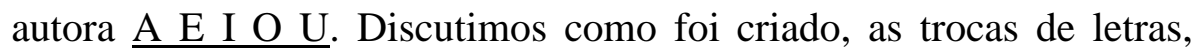
importância das imagens e combinação delas. Resultou numa leitura, 
que tinha por base a pergunta O QUE É O QUE É? Passamos, em seguida, para a brincadeira de charadas centradas nas letras como ela brincou no livro;

5. Encontro com poesia. Partimos do poema Trem de ferro de Manuel Bandeira, ouvimos a Bachiana, de Villa Lobos. Discussão sobre ritmo, musicalidade, repetição de palavras etc. Depois, cada um escolheu uma poesia e ilustrou para ser escaneada. A ideia era digitar e ilustrar na sala de informática, mas os computadores não estavam à disposição;

6. Em círculo, contei a história "Clementina, a gata", do livro Os bichos que tive (memórias zoológicas), de Sylvia Orthof. Discussão sobre o tema amizade, maternidade, diferenças, etc. Seguida de dinâmica em que cada aluno imitou um bicho, e o grupo tentava identificar qual era, depois o aluno explicava por que se identifica com o bicho que escolheu imitar;

7. Alguém contou uma história interessante, engraçada sobre seu bicho de estimação e trouxeram fotos. Leitura de outro conto do livro de Sylvia Orthof.

8. Escreveram um conto sobre bicho de estimação e trocaram fotos dos animais. Fizeram ilustrações no laboratório de informática;

9. A terceira obra de Angela Lago trabalhada foi Sete Histórias para sacudir o esqueleto. Contei uma história e analisamos encadernação, cores, ilustração e traçado trêmulo. Depois fizemos leitura em voz alta do conto "Encurtando o caminho", ilustrado no computador;

10. Leram e analisaram o poema O Jogo da Fantasia, de Elias José, relacionando com o livro Onda, de Susy Lee. Leram as imagens e criaram textos próprios. Depois ilustraram no computador;

11. Visitaram o site de Angela Lago e assistiram ao vídeo do Itaú Cultural;

12. Leitura dos textos produzidos pelos alunos a partir do livro $\underline{\text { Onda }}$ e $\underline{\mathrm{O}}$ Beijo da palavrinha, de Mia Couto. Discussão de como o autor se utiliza da palavra graficamente e figurativamente: "E se afogou numa palavrinha”. A questão da escolha das palavras na poesia, polissemia e estética. Leitura dos poemas feitos pelas crianças da Escola Municipal Júlia Lopes do $5^{\circ}$. Ano (Morro dos Prazeres em Santa Teresa). 
Momento de leitura de poemas em vários livros retirados da própria biblioteca da escola, escolha de alguns e depois leitura em voz alta. Escolheram poesia para ilustrar no computador;

13. Cine pipoca, As Crônicas de Nárnia. Finalização dos trabalhos do semestre.

Registrei como apontamentos para uma avaliação que no CIEP Teotônio Vilela, em 2012/1 ${ }^{\circ}$. Semestre, as atividades transcorreram com boa participação do grupo. A média de alunos presentes ficou em torno de 20 , atendi quatro turmas de $4^{\circ}$ ano no horário do almoço (entrada dos alunos da tarde e saída dos da manhã - contraturno). Houve apoio das professoras e da direção. Participei da Feira Literária com alegria do grupo. O maior problema foi a sala de informática, às vezes sem internet ou ocupada, mas acabei resolvendo com o técnico, e conseguimos realizar bons trabalhos. Creio atingiremos o objetivo final: um ebook feito por eles. Realizei os 13 encontros.

Como no CIEP Coronel Sarmento, situado na comunidade do Alemão, houve mudança de direção na escola, e passamos por um bom período de adaptação de horário e grupo. A nova diretora apoiou o projeto, mas necessitou trocar o horário, ficamos com quarta-feira no final do turno, com os alunos que precisam ficar até às $16 \mathrm{~h} 20$. Os alunos não têm escolha, são encaminhados para minha oficina. Por isso tive problemas com disciplina, faltas e pouco interesse e produção. Fiquei devendo dois encontros.

Quanto ao CIEP Willy Brandt, comunidade do Jacaré, foi meu melhor grupo, pois tive parceria efetiva da professora e consequentemente os trabalhos foram os melhores, mais numerosos e com maciça participação. Leram e escreveram mais, mas a questão da ilustração ficou um tanto falha, pois além de poucas máquinas (4 computadores foram roubados), não havia técnico e perdi alguns trabalhos na hora de arquivar. Realizei os 13 encontros previstos.

Penso que antes de entrarmos nas atividades do segundo semestre cabe a reflexão proposta por Sonia Kramer referente à leitura: Leitura é hábito? É gosto, prática, relação, exercício, instrumento, necessidade? (apud Fonseca, 2004: 34). E prossegue, assumindo a importância da leitura se constituir como experiência do que é vivido, narrado, compartilhado, assumindo um caráter histórico, pois vai além do tempo vivido. A leitura só será formadora se concretizar-se como 
experiência, embora possam coexistir outros propósitos de leitura, como divertimento, informação etc. De posse da leitura como experiência, continuo meu planejamento e ação focados na formação de leitores.

Já no segundo semestre de 2012, refiz o planejamento para estas escolas, procurando que tivessem novas leituras:

1. Contação de história: A fábula do imperador chinês. Segundo momento: sala de informática para nova visita ao site de Angela Lago;

2. Ciranda de livros escritos por Angela Lago - relato das impressões sobre enredo, personagens, ilustração e opinião sobre as obras lidas;

3. Livro A Formiga Aurélia e Outros Jeitos de Ver o Mundo - conto "Os Artistas Chineses e Gregos". Contação de história e discussão sobre a importância das cores, especialmente o vermelho (para os chineses) e branco (para os gregos). Leitura do conto "O Alfaiate Desatento" cada aluno leu um parágrafo. Pesquisamos sobre cores na internet;

4. Francisco Gregório Neto, escritor e contador de histórias, apresentou-se para o grupo da escola Teotônio Vilela. Contou histórias e falou de sua vida de escritor. Não pode ir ao CIEP Coronel Sarmento e nem Willy Brandt. Nessas duas escolas, trabalhamos o livro de imagens Menino de Rua, de Angela Lago, escrevendo a história;

5. Iniciamos a escrita de nossas histórias para o e-book. A turma da escola Willy Brandt escolheu como tema os morros do Rio, especialmente Pedra Bonita por causa dos voos de asa delta (passearam pelo Rio na semana anterior, daí a motivação); a turma do Teotônio Vilela escolheu escrever algo que se passasse no deserto, e iniciamos a pesquisa em livros e revistas da biblioteca de como era a vida e onde ficavam localizados os desertos no mapa mundi; a turma do Coronel Sarmento interessou-se por árvores. Buscamos na sala de leitura histórias sobre árvores;

6. Os oito encontros seguintes foram pesquisando, escrevendo e ilustrando o e-book. Assistimos a diferentes filmes: deserto (Azur e Asmar); a árvore escolhida foi Baobá (Kiriku e a feiticeira); montanhas do Rio de Janeiro (Rio) - todos desenhos animados;

7. Escrita e reescrita das histórias; 
8. Ilustração - começamos fazendo na sala de informática, mas tivemos problemas nas máquinas e optamos por ilustrar no papel e depois escanear;

9. Participamos do Paixão de Ler expondo o e-book para os colegas da escola (algumas turmas visitaram a sala de informática para lerem no computador).

Revendo o planejamento, a realização das atividades e seus resultados, é pertinente salientar a necessidade de adequação ao grupo, as impossibilidades de ordem prática (computadores e espaço), a demanda da comunidade, enfim, a soma de fatores que direcionarão o trabalho, vide a experiência em 2011 com os alunos do "acelera" do CIEP Chanceler Willy Brandt.

A questão da não obrigatoriedade da presença dos alunos nas oficinas traz dois pontos importantes a serem considerados: o primeiro positivo, pois o oficineiro é levado sempre a superar a criatividade e ser excelente observador, pois só trazendo algo muito interessante para os alunos, a oficina se mantém; o outro é negativo, pois a circulação de novos participantes faz com que o trabalho avance em passos mais curtos, às vezes tendo que retroceder para continuar; no entanto, aqueles que ficam, saem modificados pela beleza dos textos literários e por toda a dimensão de mundo que eles descortinaram.

$\mathrm{Na}$ mudança de planejamento de um ano para o outro, considerando a oferta de leitura literária, julguei a oficina ineficaz em 2011. No ano de 2012, passei a levar uma mochila de rodinhas carregada de livros que aos poucos foram sendo requisitados para serem lidos em casa. Começamos um troca-troca.

Associar leitura e escrita é compensador quando ouvimos dos participantes ao lerem e verem seus e-books os seguintes comentários:

- gostaria que meu pai visse o trabalho;

- não podemos imprimir e levar para casa?;

- como podemos jogar/publicar na internet?

Assim, no $2^{\circ}$. semestre de 2012, Escola Municipal Teotônio Vilela, as atividades começaram em abril e finalizamos em novembro: a média de presença foi de 15 alunos ao longo do ano. Começamos com 30 alunos de 4 turmas de $4^{\circ}$. ano, duas da manhã e duas da tarde. O horário era no contra-turno, ou seja, 11:30 às 13:30h. Depois de apresentar a proposta para diretora, que a achou adequada 
para essa série, fui até as salas fazer propaganda e houve adesão. A faixa etária estava correta e responderam bem às atividades de leitura e a seus desdobramentos lúdicos.

A oficina acontecia basicamente na sala de leitura e laboratório de informática. Algumas vezes precisei mudar o planejamento por ocupação da sala ou falta de computador. Dentro do possível, tudo foi contornado e direção deu o apoio possível.

No $1^{\circ}$. semestre participamos da feira literária da escola e no $2^{\circ}$., da Farra de Brinquedos no Calouste Gulbenkian e recebemos a visita de um autor em setembro, Francisco Gregório Filho.

Avançamos como parceiros, relação amistosa e de apoio com a escola, mas penso que se as professoras estivessem mais envolvidas, a produção textual teria sido maior. Contudo os alunos leram mais e dos 15 finais, 5 ficaram envolvidos com os livros, toda semana retiravam um novo. Foi um grande avanço e adoraram participar do livro digital. Escrita virtual é o espaço preferido. Combinamos manter o grupo no próximo ano, para aprofundarmos o que foi feito em 2012.

Já no CIEP Coronel Sarmento como a proposta desse ano era leitura no computador e em livros de contos e poesia, o grupo (alunos de $4^{\circ}$. e $3^{\circ}$. anos) ficou motivado, mas as atividades aconteciam no final do turno escolar, o que prejudicou bastante a qualidade do trabalho; por já estarem cansados, muitos faltavam, comprometendo a continuidade das atividades. A média de alunos ficou entre 20 e 10 participantes, mas algumas vezes apenas 5 alunos compareciam. Quase não tive contato com as professoras, apesar da direção ser presente. O laboratório de informática vivia ocupado no primeiro semestre e houve troca de professora na sala de leitura, sem que eu pudesse estabelecer parceria com a nova.

Embora as condições fossem adversas, consegui que levassem livros para casa e confeccionamos nosso e-book. A pessoa que ficou no final do ano no laboratório de informática, apoiou a oficina e cooperou na montagem do e-book. A coordenadora pedagógica pediu que passasse para as professora a criação das crianças, mas infelizmente, não foi possível: a escola fica muito confusa no final do ano.

Registrando o que se passou no CIEP Chanceler Willy Brandt, lembro-me que ao tomar conhecimento da proposta de leitura e escrita da oficina, a diretora 
combinou com a professora do $5^{\circ}$. ano que todos de sua turma participariam e trabalhamos em dupla durante todo ano (30 alunos em média). A parceria deu muito certo: dividíamos as atividades e a parte do computador ficava comigo. Teria sido perfeito, não fosse terem roubado os computadores. Acabamos fazendo o trabalho manual e só nos últimos encontros pudemos usar de novo a sala de informática quando receberam computadores novos.

Os alunos ficaram tão envolvidos que superamos a questão da falta dos computadores nas atividades de pesquisa, lúdica, escrita e ilustração. Na Paixão de Ler, o e-book estava pronto e ficaram encantados com sua criação. Os alunos queriam que eu fosse participar da reunião de pais de final de ano para que me conhecessem e mostrarem o que produziram. Lamentei não ter acontecido. Tínhamos também como conclusão do ano, um passeio a Paquetá para ver a Orquestra Jovem, mas a questão da condução, que envolve a CRE, é um complicador permanente.

Penso que ligar livro e computador é uma proposta que mobiliza a garotada. Planejei culminar as atividades num encontro com a escritora Ângela Lago, que tem seu processo criativo ligado ao computador, com site interativo, que aproxima as crianças dessa linguagem e foi muito bom. Lamentei não ter ocorrido o encontro dela com os três grupos, pois teria coroado nossa Literatura em Rede.

Também pensei sugerir que ao invés de serem 2 horas corridas, uma vez por semana, nossos encontros fossem duas vezes de uma hora. A capacidade de concentração das crianças não dura tanto tempo e dois encontros semanais estreitariam os laços e não haveria tanto espaço de tempo entre um encontro e outro. Melhoraria o vínculo, logo o trabalho.

É gratificante perceber que o "produto" faz com que sintam orgulho e confiança na aceitação dos colegas e familiares. Eles passam a acreditar na possibilidade de um trabalho criativo, e o copiar fica em outra dimensão. Tornaram-se mais críticos e "poderosos". A perspectiva de poder continuar com eles poderia de fato, confirmar se um tempo mais longo de convívio, aprofundaria o gosto pela leitura. 


\section{5 \\ Tempo que se esgota, sem fim de papo}

A leitura do texto literário, em seus diferentes gêneros, proporciona ao aluno se localizar em um universo letrado cultural, contribuindo de maneira única para a formação de um leitor crítico, capaz de articular o mundo das palavras entre si e a comunidade onde ele se insere. É o reconhecimento dessa singularidade da literatura na formação de qualquer leitor que tem acontecido nas oficinas que tratamos nessa dissertação. Utilizamos quando necessário os livros da biblioteca das escolas que hoje contam com um acervo bem melhor devido à aquisição de obras literárias pelo Programa Nacional Biblioteca da Escola (PNBE) do Governo Federal. Dentro das características de um país como o nosso, em que parte da população depende de programas assistenciais para as condições básicas de sobrevivência, torna-se complicado manter o acesso aos livros por parte da classe social carente. No entanto, com um bom trabalho de mediação, muito pode ser feito a partir do acervo (PNBE) oferecido pelo governo federal nos últimos anos.

Apesar dos esforços em várias esferas do governo federal para construção de uma educação de qualidade realizada nos últimos anos, ainda contamos com um sistema de gestão e operacional caóticos, infindos trâmites burocráticos, desconfiança da sociedade civil, indiferença evidente na corrupção política esvaziando de sentido a formação a que se propõe. No último levantamento realizado, o Índice do Desenvolvimento da Educação Básica (IDEB), aponta o Brasil em penúltimo lugar, só acima da Indonésia. A mídia chama atenção para problemas na gestão escolar, no corpo docente, na verba destinada para as escolas, sem mencionar uma concreta mudança na funcionalidade do sistema educacional, assim como sua organização.

Uma rápida avaliação do Estado na promoção da leitura, revela falta de decisão política, suas estratégias não encadeadas, a intermitência e superficialidade dos programas. Bons projetos não bastam. Como formar leitor se estatisticamente o professor é um não leitor? Como formar professores leitores 
que façam o papel da mediação despertando o interesse pelos livros, revertendo toda a metodologia da difusão da leitura na escola?

O desafio para as escolas de hoje representa uma tensão entre seu papel tradicional de transmissão de informação e conhecimento, para ensinar a leitura e a escrita e a incorporação de práticas sociais e culturais de leitura e escrita. Assim, o papel do mediador na escola, os professores do ensino de leitura é cada vez mais desafiador, na medida em que a escola tradicional apresenta problemas ao realizar a tarefa da leitura. Repensar suas estruturas de poder, avaliação e metodologia pedagógica se faz necessário.

O programa do Ministério da Cultura que forma agentes de leitura, estratégia do Plano Nacional do Livro e Leitura (PNLL) visando à democratização do acesso ao livro e formação leitora, atendendo comunidades que recebem bolsa família já em curso desde 2011 é uma iniciativa valiosa para difusão da cultura escrita. Importante reconhecer-se como leitor e saber do valor da leitura na condição social e cultural. Conforme artigo do jornal O Globo de 1/1/2011, Os desafios de Dilma na Educação, por Eliana Yunes, "é preciso priorizar a educação dentro e fora da escola". Proporcionar acesso aos bens culturais, valorizar os professores, dar melhores condições em sala de aula, comprometer família e sociedade no acompanhamento das atividades educacionais, ainda não é realidade.

O projeto do Segundo Turno Cultural é uma iniciativa das secretarias de Cultura e Educação do município do Rio de Janeiro com atividades culturais realizadas no espaço escolar. São oficinas diversas que acontecem para aqueles que se interessarem. Os alunos que participam têm a possibilidade de construir um olhar mais sensível e crítico para as obras de arte e o que está ao seu redor. Entretanto, não há ainda estudos que verifique o quanto a participação no programa interfere no rendimento escolar, o que poderia dar maior credibilidade a esse tipo de ação.

As oficinas de leitura do Segundo Turno Cultural, Encontros de Leitura e Ateliê de Histórias, objeto de minha observação, assim como a oficina Literatura em Rede, onde atuei como dinamizadora, todas em Escolas do Amanhã, no município do Rio de Janeiro em 2012, contribuíram de alguma forma para difusão do texto literário como experiência cultural. As formas de leitura como o texto literário foi apresentado: a contação de história, a confecção de objetos artísticos a partir das histórias ouvidas ou lidas, realização de peça teatral, atividades lúdicas, 
assim como confecção de máscaras, móbiles e escritura de e-books, conseguiram expandir a sensibilidade, abrindo possibilidades diversas de leitura que passaram a fazer parte do repertório de cada um, o que contribui para um olhar mais humanizador do mundo.

Cito Birman, (1994, p.104):

\begin{abstract}
"A leitura é mais uma forma de aprimoramento da sensibilidade do que de educação, justamente porque o que está em causa não é apenas o entendimento, mas principalmente a subjetividade do leitor. Após a leitura de um texto que ressoa, o leitor não é mais o mesmo, já que algo de fundamental a respeito do seu ser e do desejo foi revelado e provocado.” (Birman, 1994, p.104)
\end{abstract}

Apesar de considerar a experiência do projeto Segundo Turno Cultural um diferencial no trabalho com o texto literário na escola, entendo que políticas públicas devam ser articuladas e tenham uma dimensão mais ampla. A proliferação de projetos realizados por ONGs, pelo Ministério da Educação e Cultura, associações religiosas ou de caráter assistencial, enfim, várias instituições realizam projetos em prol da educação, mais especificamente, na formação de leitores. No entanto, esses projetos, muitas vezes, carecem de base teórica ou são projetos sem continuidade, cuja eficácia do trabalho não é avaliada.

As políticas públicas geralmente falham na questão da continuidade das ações. A mudança de governo ou até mesmo de um secretário ou diretora de escola, atrapalha o andamento dos projetos que estabeleceram laços com a comunidade e se integraram no cotidiano da escola, proporcionando experiências culturais diversas que não chegavam até eles, devido às distorções sociais e econômicas.

Na maioria das vezes, a unidade escolar não é previamente consultada sobre suas necessidades e nem participa da elaboração das iniciativas oferecidas ou impostas pelas secretarias de governo.

Enfim, a escola que é um espaço comum, de todos, passa a ser de ninguém. Tanto gestores, como corpo docente e discente parecem descrentes da política que está "invadindo" o espaço escolar. Palavras-clichê como recuperação, tecnologia, globalização, avaliação, demanda mercadológica, inclusão, democracia, relações éticas, justiça... Há de se perguntar se não seria necessário inventar outras palavras, ressignificar algumas e mesmo se a escritura literária daria conta de tanto esvaziamento do real? Ou então, não seria o momento de se 
criar uma política pública que norteasse a educação com propostas que proporcionassem abertura e ligação com o mundo, onde coubessem criatividade, conhecimento prático e formação da subjetividade com contornos bem delineados para as escolas não ficarem expostas a tantas atividades, mas sem algo consistente que de fato contribua para a formação dos alunos?

A falta de norte denunciado anteriormente é grave e precisa ser objeto de reflexão e mudanças nas atuais políticas públicas de educação e cultura. Em relação à rede municipal do Rio de Janeiro pode-se perceber que há muita diversidade nas formas de gestão, isso quer dizer que em algumas escolas a falta de integração e continuidade de programas causa problemas gravíssimos, porém em outras, a própria escola consegue dar uma organicidade aos projetos e se beneficiar dessas ações.

Em uma das escolas que já realizei minha oficina, durante um ano e meio, ao me despedir da diretora no final das atividades de 2012, ela me disse não saber se haveria continuidade do Segundo Turno Cultural, nem do projeto Mais Educação ou apoio nos laboratórios de informática no ano de 2013. Senti um certo cansaço e insatisfação em sua voz. Talvez a falta de ser consultada, falta de planejamento, falta de força política, falta de escolha sejam mais que hipóteses para minha leitura de seu semblante e voz cansados.

No entanto, existem experiências de escolas que criam procedimentos de registro de sua história através dos textos escritos pelos alunos desde que entraram bem pequenos até finalizarem a primeira etapa do Ensino Fundamental em cadernos que se chamam cadernos de memória. Eles os levarão consigo ao concluírem a primeira etapa escolar de suas vidas, ficando registrados a história pessoal da produção textual com suas impressões, leituras que foram sendo realizadas ao longo do primeiro ciclo do Ensino Fundamental. A incerteza que faz parte do novo, suas alegrias e frustrações, atingirão em menor impacto esse espaço, já que procuram registrar o que vivem com a escrita de textos pessoais. São textos com histórias que se cuidadosamente forem estudados, mostram mudanças, o progresso intelectual e ético que estão na vida dessas crianças, que registraram muitos momentos, mas não passaram pela formatação mecânica de leitura e escrita. Criar esses cadernos é devolver aos proprietários seu retrato construído, com certeza um "diploma” muito significativo. 
Considerando essa diversidade da rede, a receptividade e o aproveitamento das oficinas de leitura do projeto Segundo Turno Cultural também foram diferenciadas.

Ciente dessa realidade, ainda assim reitero que o projeto Segundo Turno Cultural contribuiu para que algumas crianças tivessem uma experiência nova com o texto literário. A experiência de aprendizado ganhou fôlego nas oficinas que observei e realizei, graças ao talento das crianças, às várias linguagens artísticas utilizadas, à participação e interesse dos alunos que voluntariamente as escolheram, ao estabelecimento de uma outra comunicação escola/família/oficina/comunidade, à socialização das leituras dentro e fora do espaço escolar, à mediação preocupada com processo da subjetivação dos participantes, à criação de uma cultura através da liberdade de expressão, mudando o foco da cultura do fracasso, que tão bem conhecem. O projeto quer somar forças, porém o próprio sucesso das atividades é indicador de fracasso do sistema tal como está. Exercício de troca e escuta, fundindo linguagens para redimensionar sua/nossa percepção de mundo.

Entender o leitor como aquele que é capaz de ler tanto os textos quanto a realidade e, assim, sabendo situar-se socialmente, reivindicar seus direitos de cidadania, estimulados por vivências culturais diversificadas é o objetivo principal do projeto do Segundo Turno Cultural. No entanto, participar de atividades culturais fora da escola nem sempre é possível por falta de condução. Ir ao cinema, teatro, visitar museus, exposições, conhecer os pontos turísticos de uma das cidades considerada mais bela do mundo seria fundamental para romper com a dura realidade das Escolas do Amanhã situadas na cidade "maravilhosa", um dos problemas apenas.

As crianças vivem em um espaço que é considerado um patrimônio da humanidade, vivenciam oficinas culturais nas escolas, mas resta conhecer um outro lado da cidade, dinâmico, plural de riquezas físicas e artísticas, o que lhes daria uma dimensão nova, um contraponto de luzes do palco, consciência de histórias passadas e vividas através da arquitetura, do cinema, da música, do teatro. Visitar salas de exposição, entrar num bondinho e ver lá do alto o mar, com praias, com espaços para lazer, floresta e o Cristo de braços abertos, certamente faria dessas crianças outras, mais leves, mais interessadas, vislumbrando outros 
horizontes que também constituem o espaço em que vivem, apesar da crueza econômica que deles as distanciam.

Sim, políticas públicas para possibilidades outras, onde caiba poesia, cor, sorrisos, brincadeiras, telas inquietantes ou cenas como ver uma escultura de um homem em cima de prédio como aconteceu na exposição do artista plástico londrino, Anthony Gormley, no CCBB, em outubro de 2012. Coisas sem pé nem cabeça, mas com um sentido apontado para possibilidade de existir de forma mais ajustada consigo mesmo e mais justa na sociedade. 


\section{6 \\ Referências Bibliográficas}

AGUILAR, A. S. Era uma vez Dom Quixote. São Paulo: Global, 2005.

ALVES, R.; BRANDÃO, C. R. Encantar o mundo pela palavra. Campinas: Papirus, 2006.

ANGROSINO, M. Etnografia e Observação Participante. Porto Alegre: Artmed, 2009.

BÁEZ, F. História universal da destruição dos livros. Rio de Janeiro: Ediouro, 2004.

BARTHES, R. O prazer do texto. $4^{\text {a }}$ Ed. São Paulo: Editora Perspectiva, 1996.

BIRMAN, J. Leitura crítica: questões sobre recepção. In: Simpósio Nacional de leitura, Rio de Janeiro, 1994. Leitura, saber e cidadania. Rio de Janeiro: 1994. p.103-112.

BRANDÃO, Z. Pesquisa em Educação. Rio de Janeiro: Ed. PUC-Rio; São Paulo: Loyola, 2002.

CANCLINI, N. G. Culturas Híbridas. São Paulo: Edusp, 2008.

CARNEIRO, F. Entre o Cristal e a Chama. Rio de Janeiro: EdUERJ, 2001.

CHARTIER, R. A aventura do livro: do leitor ao navegador. São Paulo: UNESP, 1998.

A ordem dos livros. Brasília: UnB, 1999.

COLOMER, T. Andar entre livros - A leitura literária na escola. São Paulo: Global Editora, 2007.

COSSON, R. Letramento Literário - teoria e prática. São Paulo: Contexto, 2006.

COUTO, M. E se Obama fosse africano? São Paulo: Companhia das Letras, 2011.

CULLER, J. Teoria Literária - uma introdução. São Paulo: Beca Produções Culturais Ltda, 2001.

DENZIN, N. K.; LINCOLN, Y. S. O Planejamento da Pesquisa Qualitativa: teorias e abordagens. Porto Alegre: Artmed, 2006. 
EVANGELISTA, A.; BRANDÃO, Heliana e MACHADO, Maria Zélia. A Escolarização da Literatura - O Jogo do Livro Infantil e Juvenil. Belo Horizonte: Autêntica, 2001.

FERNANDES, C. R. Práticas de leitura escolar no Brasil: representações da escola, de professores e do ensino na literatura infanto-juvenil a partir dos anos 80. Tese de Doutorado apresentada ao Instituto de Estudos e Linguagem da UNICAMP. Campinas: 2004.

FONSECA, L. M. Salas de Leitura - Concepções e Práticas. Dissertação de Mestrado apresentada ao Departamento de Educação da PUC Rio. Rio de Janeiro: 2004.

ISER, W. A interação do texto com o leitor. In: COSTA LIMA, L. (Org.). A literatura e o leitor. Rio de Janeiro: Paz e Terra, 1979, p. 83-103.

JAUSS, H. R. "O prazer estético e as experiências fundamentais da poiesis, aisthesis e katharsis", in: COSTA LIMA, L. (Org.). A literatura e o leitor. Rio de Janeiro: Paz e Terra, 1979, p. 63-82.

LAGE, M. M. Ler sem Doer. Coronel Fabriciano: Unileste-MG, 2003.

LARROSA, J. Linguagem e Educação depois de Babel. Belo Horizonte: Autêntica, 2004.

LUCAS, S. Projeto Escolas do Amanhã: Possibilidades Multiculturais? Dissertação de Mestrado em Educação apresentada à Faculdade de Educação da UFRJ. Rio de Janeiro: 2011.

MANGUEL, A. Uma história da leitura. São Paulo: Companhia das Letras, 1997.

MARIANI, B. S. C. M. "Os primórdios da imprensa no Brasil (ou de como o discurso jornalístico constrói memória)". In: ORLANDI, E. (Org.). Discurso fundador: a formação do país e a construção da identidade nacional. Campinas: Pontes, 1993.

MATOS, G.; SORSY, I. O Ofício do Contador de Histórias. São Paulo, Martins Fontes, 2005.

MENDES, A. O amor e o diabo em Angela Lago - A complexidade do objeto artístico. Belo Horizonte: Editora UFMG, 2007.

MORIN, E. Os sete saberes necessários à educação do futuro. São Paulo: Cortez, 2002.

OLINTO, H. K.; SCHOLLHAMMER, K. E. (Orgs.). Literatura e Cultura. São Paulo: Edições Loyola, 2003. 
PAIVA, A.; MARTINS, A.; PAUlINO, G.; CORRÊA, H.; VERSIANI, Z. Literatura: saberes em movimento. Belo Horizonte: Autêntica Editora, 2007.

PAIVA, A; MARTINS, A.; PAULINO, G.; VERSIANI, Z. Leituras literárias: discursos transitivos. Belo Horizonte: Autêntica Editora, 2005.

PAIVA, A.; SOARES, M. Literatura Infantil: políticas e concepções. Belo Horizonte: Autêntica Editora, 2008.

PAULINO, G.; WALTY, I.; CURY, M. Z. Intertextualidades: teoria e prática. Belo Horizonte: Editora Lê, 1995.

PELlEGRINI, S. de M. História e memória do PROLER (1992 - 1996): uma experiência instituinte de leitura. Tese de doutorado apresentada ao Departamento de Letras da PUC Rio. Rio de Janeiro: 2010.

PENNAC, D. Como um romance. Rio de Janeiro: Rocco, 1992.

PETIT, M. A arte de ler ou como resistir à adversidade. São Paulo: Editora 34 Ltda, 2009.

PIGLIA, R. O último leitor. São Paulo: Companhia das Letras, 2006.

RAMAL, A. C. Ler e Escrever na Cultura Digital. Pátio. Revista Pedagógica. Artmed: Porto Alegre: v, IV, N.14, p.21-24, 2000.

ROBLEDO, B. H. El arte de la mediación - Espacios y estratégias para la promoción de lectura. Bogotá: Grupo Editorial Norma, 2010.

SELliER, M. A África meu pequeno Chaka... São Paulo. Companhia das Letrinhas, 2006.

SILVA, C. M. de M. Catarse, emoção e prazer na Poética de Aristóteles. Tese de Doutorado apresentada ao Departamento de Filosofia do Centro de Teologia e Ciências Humanas da PUC-Rio. Rio de Janeiro: 2009.

SOARES, M. B. A Escolarização da Literatura Infantil e juvenil. In EVANGELISTA, A. (Org.). A Escolarização da Leitura Literária: O Jogo do livro Infantil e Juvenil. Belo Horizonte; Autêntica, 2001, p. 17-48.

VERSIANI, D.; YUNES, E.; CARVALHO, G. Manual de reflexões sobre boas práticas de leitura. São Paulo: UNESP, 2012.

YUNES, E. Tecendo um leitor: uma rede de fios cruzados. Curitiba: Aymará, 2009.

Pensar a Leitura: Complexidade. São Paulo: Edições Loyola, 2002. 
ZAPPONE, M. H. Y. Práticas de Leitura na Escola. Dissertação de Mestrado em Teoria Literária do Instituto de Estudos da Linguagem apresentada à Faculdade de Letras da UNICAMP. Campinas: 2001.

ZILBERMAN, R. A Literatura Infantil na Escola. São Paulo: Global, 2003.

Como e por que LER a Literatura infantil Brasileira. Rio de Janeiro: Objetiva: 2005. 
7

Anexos

7.1

Experiências no Labirinto (2011)

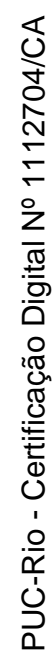

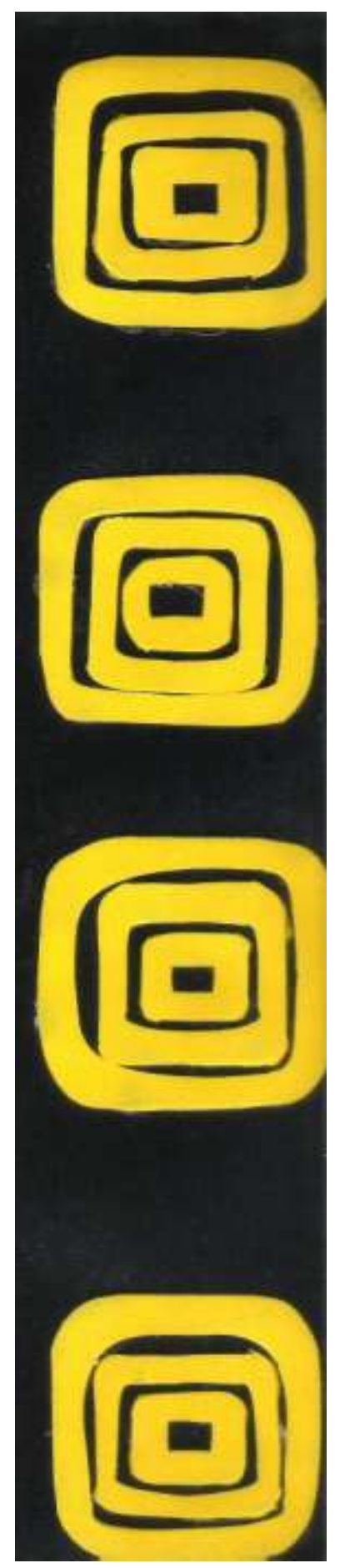


PARA SEUS SONHOS

PARA SUAS SENSAÇÕES

PARA SUAS POESIAS

PARA SEUS PROJETOS

PARA SUAS INTENÇÕES

PARA SEUS DECRETOS

PARA SEUS SEGREDOS

PARA SUAS INSPIRAÇÕES

PARA SEUS DESEJOS

PARA SUAS CRIAÇÕES

PARA SUAS INTUIÇÕES

PARA SUAS IDEIAS

PARA SUASLOUCURAS

PARA SUAS PERGUNTAS

PARA SUAS RESPOSTAS

OFICINA: EXPERIÊNCIAS NO LABIRINTO
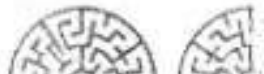


\section{OFICINA: EXPERIENNCIAS NO LABIRINTO}

\section{Professora: Maria Antonieta S. Rodrigues}

\section{INTRODUÇÃO}

Nas sociedades contemporâneas o volume de informaçōes e conhecimentos produzidos exige das pessoas competência de leitura para escolher e considerar aquilo que deve merecer sua atenção. Contudo, toda realidade humana, está contida nas linguagens, as quais demandam sujeitos leitores para criticar, apreciar, interpretar e analisar forma e conteúdo para alterar atitudes frente aos paradoxos das culturas vigentes.

A partir da oficina Experiências no Labirinto com atividades que valorizem a cultura afro-brasileira, as crianças poderão ver a importâncias dos/das africanos/as e afrodescendentes na constituição deste pais e desta nação.

Todos os saberes se equivalem e pensar nessa dimensāo de valorização nos coloca diante de um imenso universo a ser descoberto, ressignificado, reapropriado que a oficina Experiências no Labirinto nos seus 13 encontros convida para uma reflexăo além da sala de aula, ludicamente, a construçăo de um labirinto em cujo processo todos percebam o quanto somos afro-descendentes, afro-brasileiros, não importando a cor de nossa pele. Temos na nossa constituição a grande presença, a grande permanência da África no nosso dia-a-dia.

\section{JUSTIFICATIVA}

Nunca na história, a leitura foi tão valorizada socialmente e o sistema escolar em todos os niveis expandiu-se tanto; paradoxaimente as estatisticas apontam para um número cada vez menor de leitores efetivos.

Compreendendo a carência de leitores efetivos na sociedade, a oficina Experiências no Labirinto pretende contribuir para a formaçäo de subjetividade, individuaçăo do sujeito, resignificação do texto (intertexto), criação de repertório etc.

A complexidade de novos tempos exige um leitor que transite nas mais diversas linguagens, já que a través da linguagem é dado o(s) sentido (s) dos textos em sua totalidade.

\section{OBJETIVO}

OBJETIVO

Contribuir para a formaçăo de novos leitores conscientizando sobre o papel da cultura africana na formação da subjetividade e do olhar do povo brasileiro. 


\section{OBJETIVOS ESPECÍFICOS}

- Perceber o pacto entre autor e leitor nas suas associações.

- Trabalhar a intertextualidade considerando a oralidade, ancestralidade, religiosidade, musicalidade, memória, cooperaçâo/comunitarismo, ludicidade, circularidade etc.

- Relacionar os diversos aspectos da cultura africana com a atualidade, criando através de atividades lúdicas, narrativas que terão por fim último, montar um labirinto que trata da importância de uma comunicação efetiva entre as culturas que formam nosso pais.

\section{ESTRATÉGIAS}

Sabe-se da necessidade de promoçăo de atividades lúdicas na escola. A oficina Experiências no Labirinto é um espaço para isso. As atividades serão desenvolvidas em 13 encontros. As estratégias a serem adotadas pretendem provocar interesse pelo tema, assim como, as diversas linguagens no processo educativo.

A confecçăo do labirinto de papelẫo será realizada através de:

- Criação de um diário de bordo após as atividades realizadas em cada encontro marcando os passos percorridos na montagem do labirinto;

- Contaçăo de histórias (griot) e intertextualidade;

- Painel com fotografias analógicas;

- Filme: desenho animado e documentário;

- Criação de história a partir da sopa de letrinhas;

- Caça ao tesouro para montar um quebra-cabeça;

- Caixa de memória ligada à ancestralidade de cada um e memória da língua.

\section{PÚBLICO A SER ATENDIDO}

Alunos do Ensino Fundamental.

\section{DURAÇÃO DA OFICINA}

Duas horas semanais, totalizando 26 horas. 


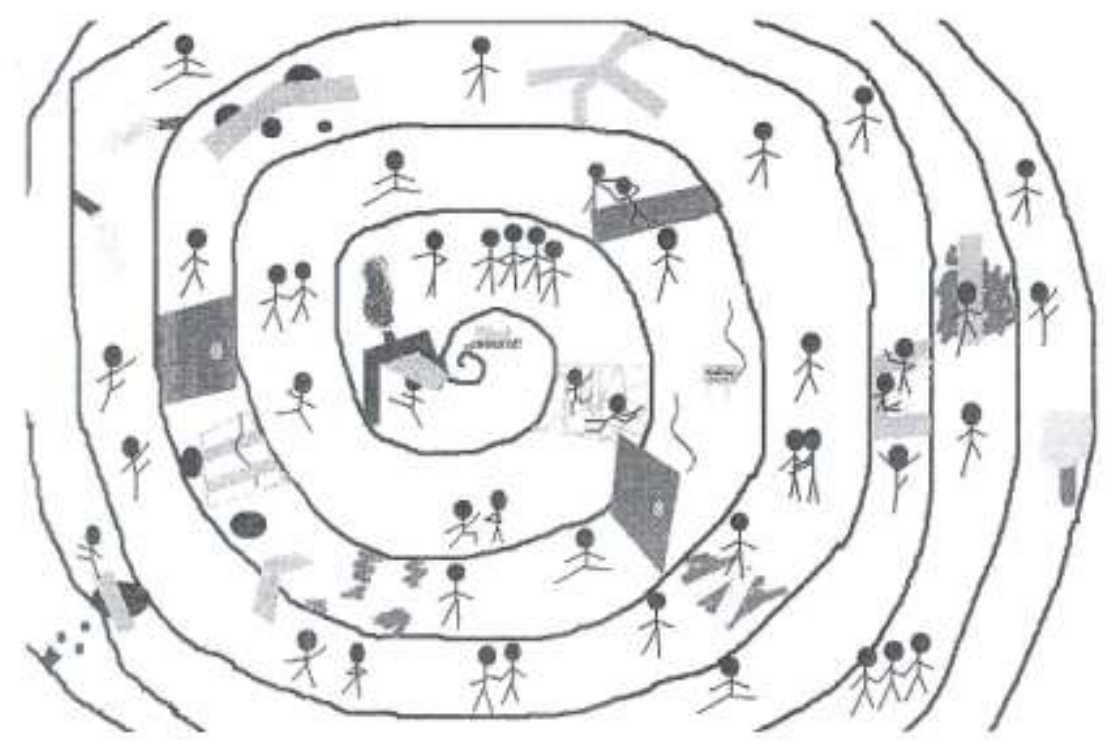

\section{EXPERIÊNCIAS NO LABIRINTO}

SEGUNDO TURNO CULTURAL

Prefeitura Municipal do Rio de Janeiro

Tema: Construção do labirinto caminhando pela África Local: CIEP Teotônio Villela

Período: 13 encontros $-1^{\circ}$ semestre

Horário: quarta-feira às $9 \mathrm{~h}$

Turmas: $4^{\circ}$ e $5^{\circ}$ anos

Início: 6 de abril de 2011

Término: 6 de julho de 2011 


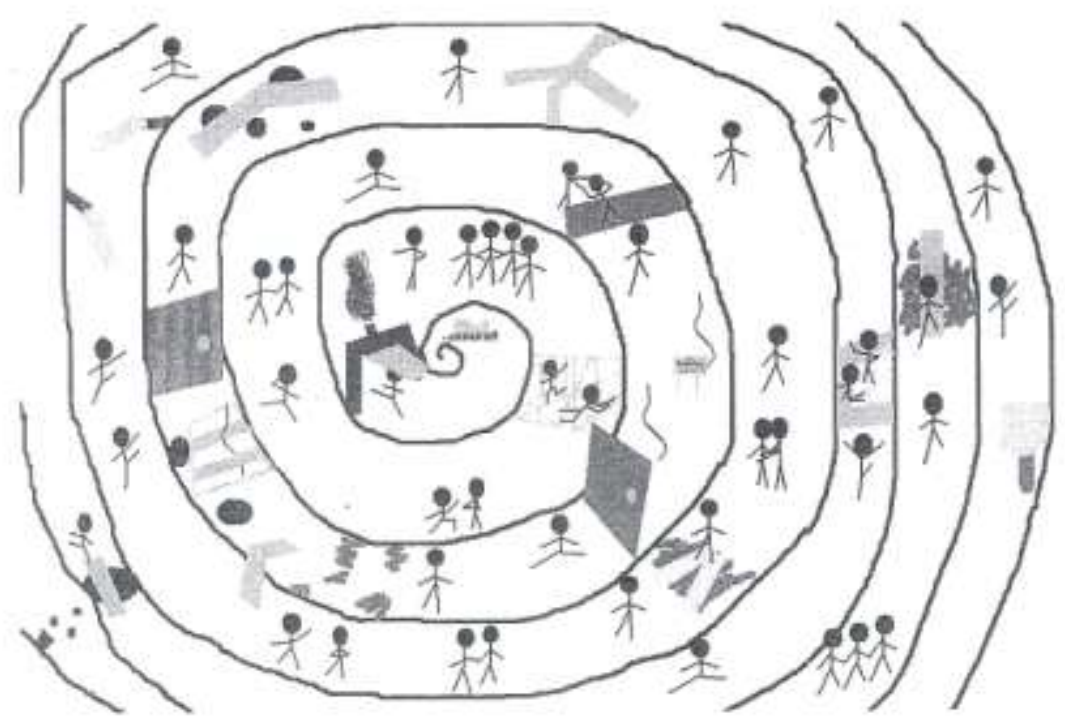

\section{EXPERIÊNCIAS NO LABIRINTO}

SEGUNDO TURNO CULTURAL

Prefeitura Municipal do Rio de Janeiro

Tema: Construção do labirinto caminhando pela África Local: , CIEP Hélio Smidt

Período: 13 encontros $-1^{\circ}$ semestre

Horário: quarta-feira às $12 \mathrm{~h}$

Turmas: $4^{\circ}$ e $5^{\circ}$ anos

Início: 6 de abril de 2011

Término: 6 de julho de 2011 


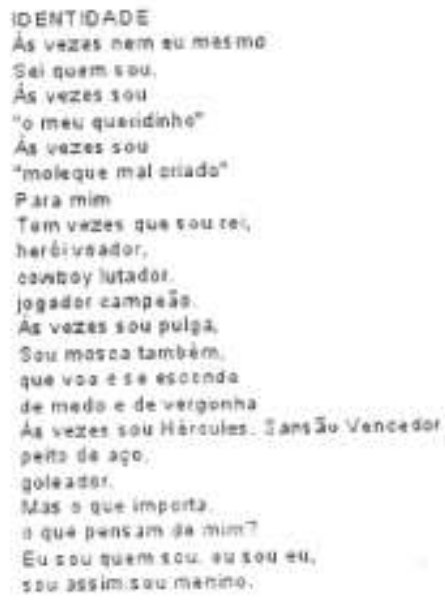

1. Nome:

2. Apelido:

3. Idade:

4. Composição familiar:

5. Ano escolar:

6. Um esporte:

7. Um Lazer:

8. Uma qualidade:

9. Um defeito:

10. Uma alegria:

11. Uma tristeza

12. Um sonho:

13. Um medo:

14. Uma esperança: 


\section{A Lenda do Minotauro}

o Minotauro (touro de Minos) é uma figura mitológica criada na Grécia Antiga. Com a cabeça e cauda de touro num corpo de homem, este personagem povoou o imaginário dos gregos, levando medo e terror. De acordo com o mito, a criatura habitava um labirinto na litha de Creta que era governada pelo rei Minos.

Conta o mito que ele nasceu em função de um desrespeito de seu pai ao deus dos mares, Poseidon. 0 rei Minos, antes de torna-se rei da Creta, havia feito um pedido ao deus para que ele se tornasse o rel. Poseidon aceita o pedido, porém pede em troca que Minos sacrificasse, em sua homenagem, um lindo touro branco que sairia do Mar. Aa receber o animal, o rei ficou tão impressionado com sua beleza que resolveu sacrificar outro touro em seu lugar, esperando que o deus nð̆ percebesse.

Muito bravo com atitude do rei, Poseidon resolve castigar o mortal. Faz com que a esposa de Minos se apaixonasse pelo touro. Isso não só aconteceu como também ela acabou ficando grávida do animal. Nasceu desta união o Minotauro. Desesperado e com muito medo, Minos solicitou a Dédalos que este construisse um labirinto gigante para prender a criatura. O labirinto que foi construido no subsolo do palácio de Minos, em Creta, era um conjunto de corredores, salas, passagens e atalhos intrincados, construído de tal modo que todos aqueles que se enveredavam por eles não conseguiriam mais sair e acabavam sendo devorados pelo monstro.

Muito antigamente, era costume reunir jovens da elite de países vizinhos e amigos em competiçōes de luta, corrida e destreza. Numa dessas reuniōes, participaram campeōes de Creta e de Atenas. Androgeu, filho de Minos, venceu na luta os cidadăos de Atenas. Embora fosse uma competição amistosa, os atenienses não se conformaram com a derrota a assassinaram Androgeu.

Para se vingar, Minos, rei de Creta invadiu Atenas, submetendo os atenienses às mais duras penas. Todos os anos, durante trinta anos, sete rapazes e sete moças de Atenas deviriam ser entregues ao terrivel Minotauro, que se alimentava de carne humana.

Após o terceiro ano de sacrificios, o herói grego. Teseu resolve apresentar-se voluntariamente para ir à Creta matar o Minotauro. Ao chegar à ilha, Ariadne (fillha do rei Minos) apaixona-se pelo herói grego e resolve ajudálo. Teseu năo ficou indiferente aos encantos da jovem princesa e prometeu que se casaria com ela se saisse vivo daquela aventura. Comovida, Ariadna entregou a seu futuro marido um novelo de linha, para que Teseu pudesse marcar o caminho na entrada e não se perder no grandioso e perigoso labirinto. Enquanto Ariadne, do lado de fora do labirinto ia desenrolando o novelo.

O grupo de vitimas entrou no labirinto e desapareceu. Ariadne sentia as vacilaçōes e os avanços de Teseu pelos movimentos da linha que ele segurava. Logo se ouviram os mugidos terriveis do Minotauro. No fio de linha, reflexos de uma luta feroz... Depois de gritos confusos. Seriam de alegria, de tristeza ou de pavor? Depois, a linha passou a se mover mais rapidamente e com maior firmeza. Teseu estava salvol O Minotauro sucumbiral

O herói ajudou a salvar outros atenienses que ainda estavam vivos dentro do labirinto. Saíram do local seguindo o caminho deixado pelo novelo de lã.

O mito do Minotauro foi um dos mais contados na época da Grécia Antiga. Passou de geração em geração, principalmente de forma oral. Pais contavam para filhos, filhos para os netos e assim por diante. Era uma maneira dos gregos ensinarem o que poderia acontecer àqueles que desrespeitassem ou tentassem enganar os deuses. 
Ficha de observação do filme KIRIKU E A FEITICEIRA

1. Biologicamente todos os seres humanos são parecidos $e$ as pequenas diferenças físicas não interferem na capacidade de raciocinar. Como era nosso herói Kiriku fisicamente?

2. Na África tradicional, quem falta d̀ própria palavra mata a sua pessoa civil, ninguém a respeita. "Quem estraga sua palavra estraga-se a si mesmo". Qual é a promessa dada por Kiriku à sua tribo?

3. Por que os homens da tribo estavam morrendo? Quem resolve ser o "Teseu" e matar o Minotauro, Karabá?

4. Como era o labirinto de Kiriku, quem ele queria encontrar?

5. A tribo dizia muitas terríveis sobre Karabá. Quais eram as maldades de Karabá?

6. Para algumas tribos africanas a cultura oral era única fonte histórica da sua origem. Quem era o guardião da sabedoria do povo de Kiriku?

7. Escreva qual a ação de Kiriku que traz de volta a dor de Karabá? 0 que aconteceu depois?

8. Ser pequeno, a princípio era desvantagem, mas por ser justamente pequeno entra no buraco da água, passa por trilha subterrânea, voa abraçado numa ave e consegue driblar a feiticeira. Kiriku vence todos os obstáculos. No entanto, foi com muito esforço que consegue ganhar a confiança da sua aldeia. Como ele foi recebido pela aldeia quando volta com Karabá? 
Ficha de observação do filme KIRIKU E A FEITICEIRA

1. Biologicamente todos os seres humanos são parecidos $e$ as pequenas diferenças físicas não interferem na capacidade de raciocinar. Como era nosso herói Kiriku fisicamente?

2. Na África tradicional, quem falta à própria palavra mata a sua pessoa civil, ninguém a respeita. "Quem estraga sua palavra estraga-se a si mesmo". Qual é a promessa dada por Kiriku à sua tribo?

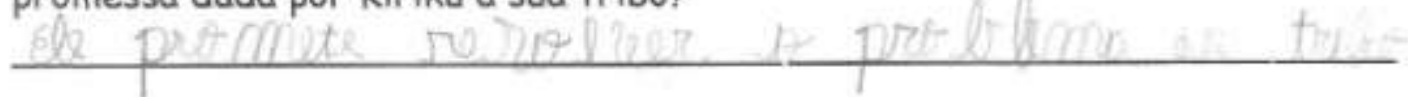

3. Por que os homens da tribo estavam morrendo? Quem resolve ser o "Teseu" e matar o Minotauro, Karabá?

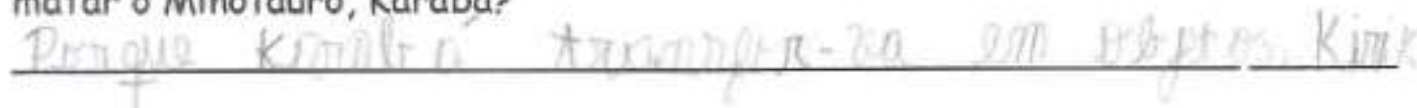

4. Como era o labirinto de Kiriku, quem ele queria encontrar?

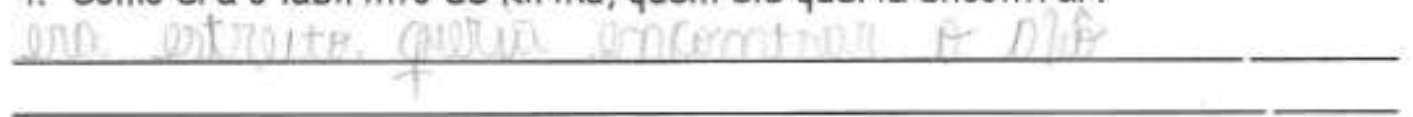

5. A tribo dizia muitas terríveis sobre Karabá. Quais eram as maldades de Karabá?

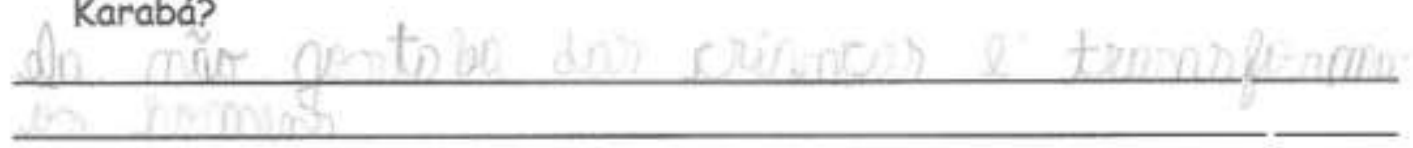

6. Para algumas tribos africanas a cultura oral era única fonte histórica da sua origem. Quem era o guardião da sabedoria do povo de Kiriku?

7. Escreva qual a ação de Kiriku que traz de volta a dor de Karabá? 0 que aconteceu depois?

8. Ser pequeno, a princípio era desvantagem, mas por ser justamente pequeno entra no buraco da água, passa por trilha subterrânea, voa abraçado numa ave e consegue driblar a feiticeira. Kiriku vence todos os obstáculos. No entanto, foi com muito esforço que consegue ganhar a confiança da sua aldeia. Como ele foi recebido pela aldeia quando volta com Karabá? 


\section{SAFARI NA ÁFRICA}

Para quem gosta de aventura, de ter contato bem de perto com animais selvagens e lindas paisagens a África é o local ideal.

Neste especial vamos fazer uma viagem por esse continente com natureza exuberante e muitos parques e hotéis especializados para quem quer fazer um safari.

Para começar vamos descrever o ambiente: o bioma predominante na Africa é a savana, que tem como característica principal o clima extremamente seco, podendo ficar até dez meses sem chuva, com temperafuras elevadas e umidade relativa do ar muito baixa. Dessa forma fique esperto e leve muita agua $e$ roupas leves para aproveitar seu safari

$\mathrm{Na}$ época das chuvas, o crescimento da vegetaçấo é acelerado, crescem árvores de até 4 metros e arbustos de até 1.5 metro.

Um tipo de bioma também característico de alguns locais da África é o bioma do serengueti com árvores balxas, em grande número, com muitos espinhos e de fothas reduzidas em tamanho para minimizar a perda de água nas épocas de seca. Há a predominăncia do cacto, da acácia, da palmeira e árvores de grande porte como o baobá, maruleira.

Assim, podemos dizer que na África há uma regiăo fronteiriça entre a fioresta mais densa e o deserto nos trópicos, ocupando uma faixa bastante grande do continente aficano.

- "auna da savana africana é composta principaimente por mamiferos de grande porte, como o búfalo, a grafa, o rinoceronte e o elefante, mamiferos de porte médio, como a zebra, o impala e antilopes, mamiferos felinos predadores, como o leăo, o leopardo e o guepardo, muitas aves, como o falcăo, a águia, o abutre e o avestruz, além é claro animais de outras espécies de animais.

Agora vamos ao Safaril

Na África existem cerca de 20 parques nacionais voltados para o turismo sustentável, portanto hă a preocupaçăo em preservar a fauna e flora. Há profissionais especializados em acompanhar grupos durante todo o safári. Na maioria destes parques săo oferecidas acomodaçőes para turistas e muitas opçöes de lazer e cuitura, incluindo a observaçăo de animais de grande porte como o leảo, leopardo, elefante, rinoceronte e búfalo.

O Kruger Park è a maior reserva para safári da África do Sul. Este parque conta com 20 mill quilömetros quadrados de área cheia de emoçóes e aventuras. A chances de encontrar logo de cara alguns animais bem ferozes é grande pois o parque tem em média 1.500 leóes, 150 mil impalas. Sem falar em 32 mil zebras, 10 mil elefantes e 9 mil girafas entre outros. O ideal é chegar bem cedo ao parque, já que os leöes podem ser observados mais à noite, mas cegando logo cedo ainda há possibilidade.

Para quem gosta de aventuras mais radicais poderá optar por percorrer uma trilha, sem guia, alugando apenas um carro para até quatro pessoas e seguindo para leste em área protegida dos animais selvagens, $O$ detalhe é que você terá que providenciar tudo, desde alimentação até as acomodaçóes para passar a noite, portanto, se não tiver experiência em acampar é melhor mudar o programal

C a opçáo bem divertida è descer o Kruger numa mountain bike. 0 passeio leva quatro horas. Cada grupo de seis ciclistas tem a companhia de dois guias armados, para qualquer eventualidade durante a trilha de até 24 quilómetros.

O Parque Addo Elefant é bem extenso e da mesma forma, cheio de aventuras. É um santuário para inúmeras espécies de animais e plantas. Os 164 mil hectares abrigarn cerca de 450 elefantes, uma das mais densas populaç̧es da espécie no mundo. No parque há, ainda, finocerontes, leōes e búfaios.

Outro parque interessante e um dos mais antigos $\mathrm{e}$ o Sabi Sandi. Fundado em 1943 o parque reúne espécies como elefantes, leб́es e rinocerontes. O safári é feito em jipes abertos, assim os animais e a paizagem podem admirados sem a limitaçâo de vidros ou grades. Aqui há a opçäo de fazer safaris durante a noite também, pois há forte iluminaçăo por holofotes.

Ainda podemos indicar o Parque Phinda que tem paisagens que variam entre savana e praias, oferecendo também a possibilidade de mergulho entre os recifes de corais.

Vamos conhecer aiguns desses animais predominantes na África, para isso consulte a ficha técnica de cada um:

$\begin{array}{ll}\text { - } & \text { Girafa } \\ \text { * } & \text { Babuino } \\ \text { Curiosidade: }\end{array}$

A África tem 11 linguas oficiais: inglês, zulu, xhosa, suázi, ndebele, sesotho do sul, sesotho do norte, tsonga, tswana, venda e afrikaans. Portanto para seu safári prepare-se para ouvir idiomas bem differentes!I! 
EXPERIÊNCIAS NO LABIRINTO, caminhando peła ÁFRICA

Maria Antonieta

Aluno(a):

Data:

INTERNET como Labirinto usando o "fio de Ariadne", Siga os passos pelo Google:

\section{CLICAR}

1: IMAGEM

Escrever: Mapa da África diáspora (página 2).

2. IMAGEM

Escrever: De quais paises vieram os escravos para o Brasil?

39 MAPAS

Arrastar com a mäozinha e ver continente sul americano e africano.

4. WEB

Escrever: Smartkids safari na África (ler em voz alta). Clicar para maiores informaçōes nas palavias: girafa, elefante, babuino e zebra.

50 Responder sobre a Africa:

1. De que continente sairam os nossos escravos?

2. Que país africano ficana altura do Rio Grande do Sul?

estado da Paraiba é o que fica mais próximo do continente africano. Que pais na África fica mais próximo de nós?

4. O que é um safari?

69. IMAGEM

Escrever: savana / serengueti / deserto / fioresta tropical africana / Rift Valley

72 JOGOS 


\section{CACA PALAVRAS RMAGS: \\ www.smartkids.com.br}

Encontre 5 animais que vivem na selva da África:

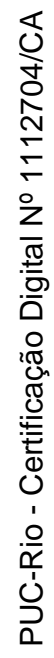

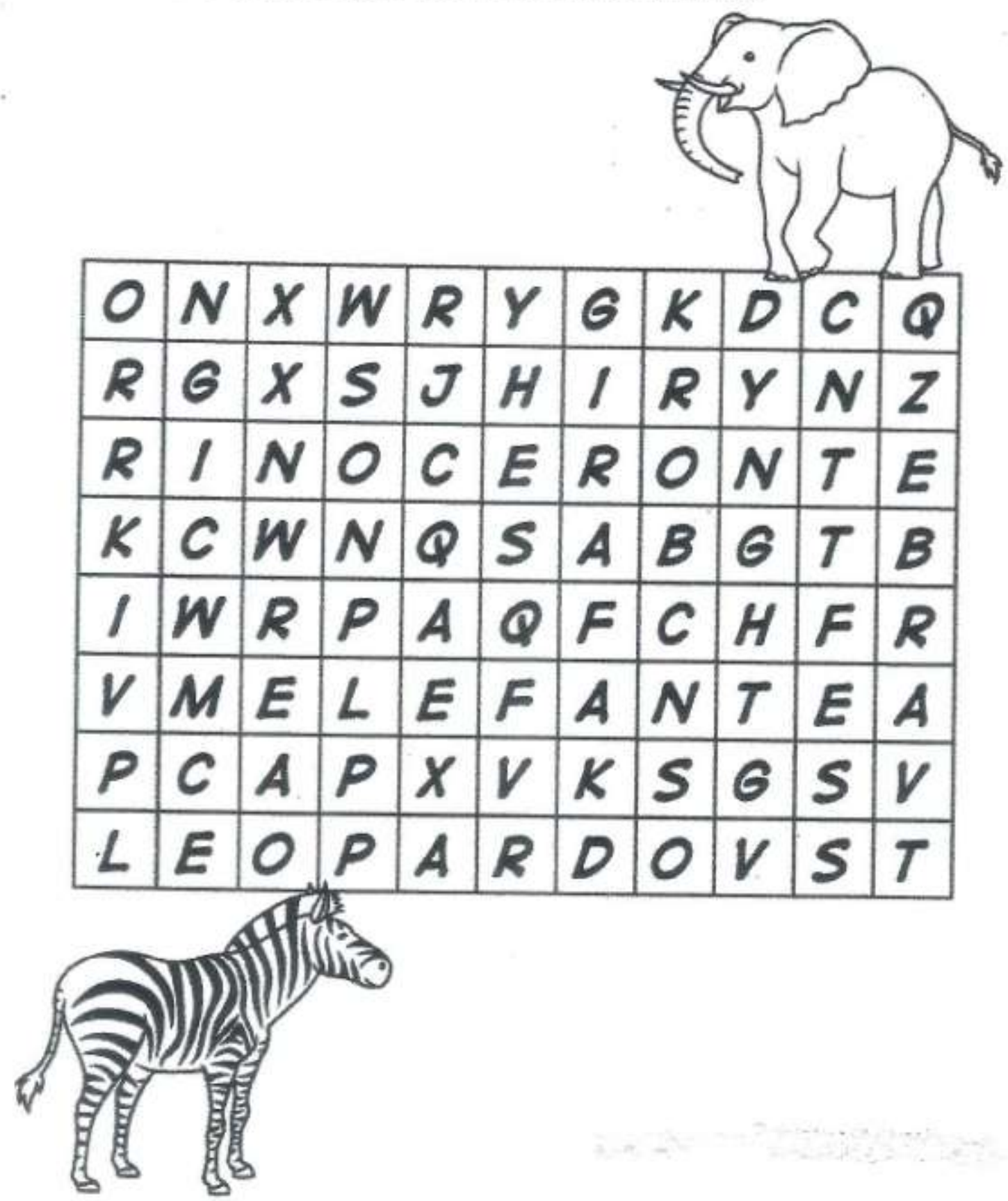

\begin{tabular}{|c|c|c|c|c|c|c|c|c|c|c|}
\hline 0 & $N$ & $x$ & $\boldsymbol{W}$ & $\boldsymbol{R}$ & $Y$ & $G$ & & $\nu$ & c & $Q$ \\
\hline$R$ & 6 & $x$ & $S$ & J & $H$ & $I$ & $k$ & $\gamma$ & $\boldsymbol{N}$ & \\
\hline
\end{tabular}




\section{COMPLETE}

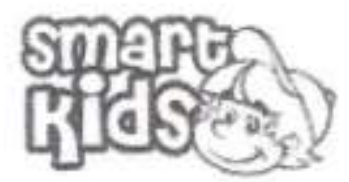

www.smartkids,com.br

Preencha cada espaço com o nome do animal que vive na regiăo indicada. Boa sorte!

\section{ÁFRICA}

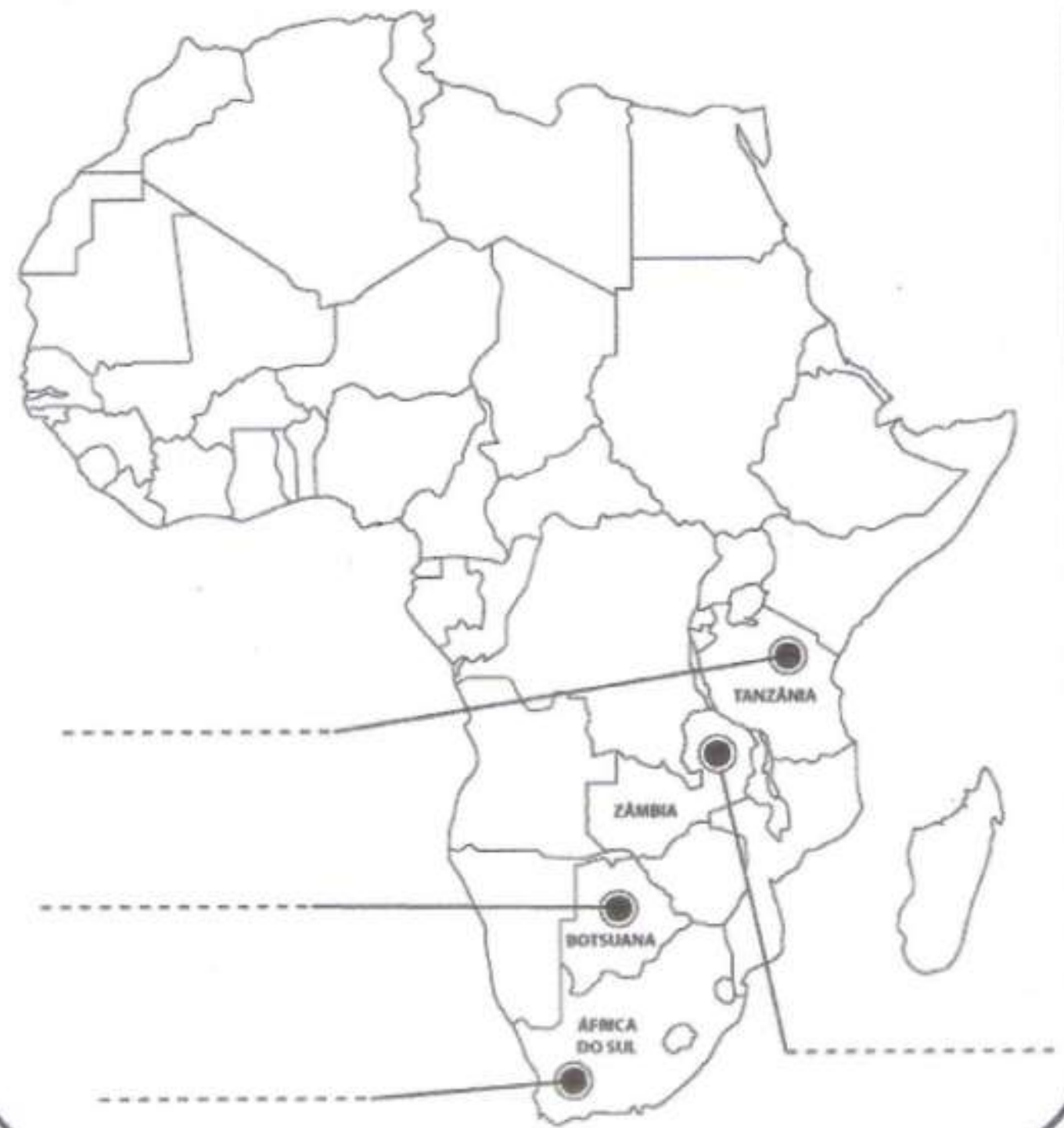




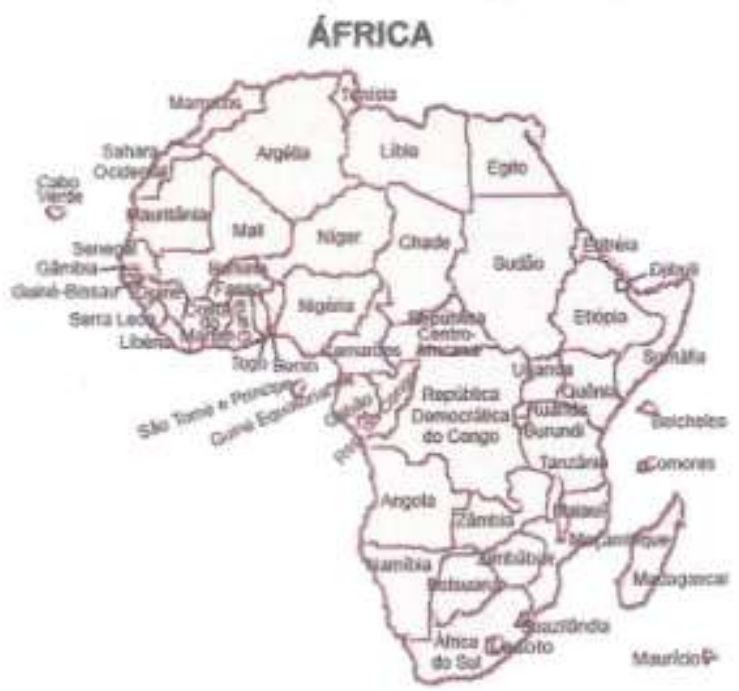

A Átrica é um continente formado por 53 paises.

O continente africano é um dos maiores que há. Em tamanho, a África perde apenas pára a Ásia e a América.

Na África, vivem 13 de cada 100 pessoas do mundo.

A partir destas pequanas informaçôes vou descrever a nossa atividade.

1-Cada ałuno deverá escother uma pessoa imaginária, de um pais da África para escrever uma carta.

Ja carta vocé o aluno deverá relatar a sua realidade e perguntar a essa "pessoa", como é a vida dela, como é a sua realidade. Assim, para cada experiència ou vivência relatada, o aluno deverá perguntar como acontece no outro pais.

3- A carta deverá ser colocada em um envelope e endereçada, com o nome do destinatério e o país, além dos dados completos do remetente.

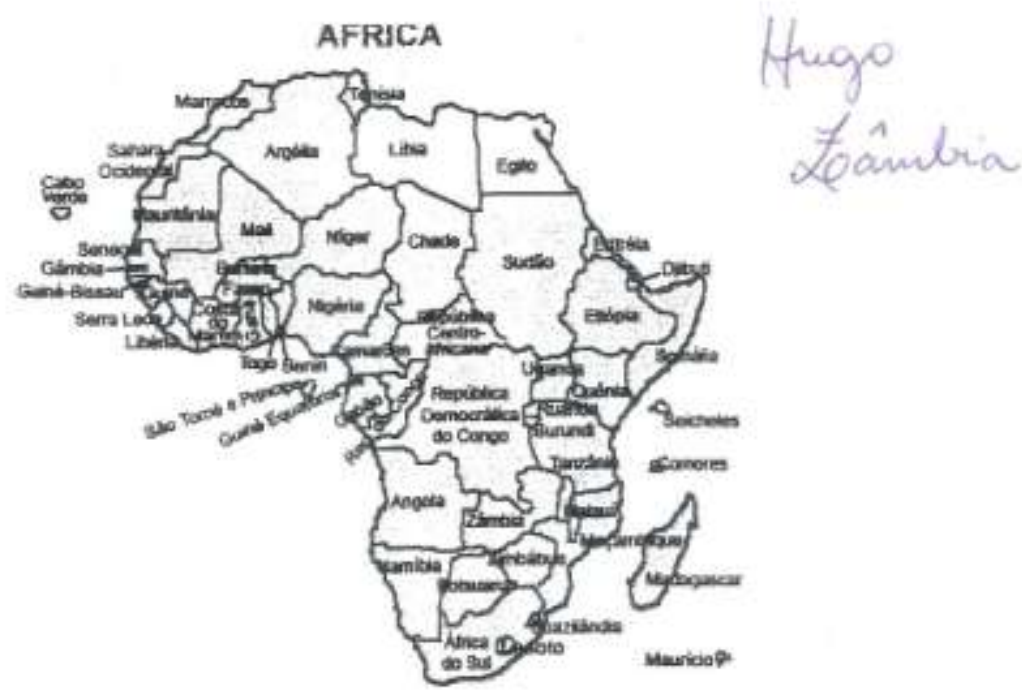

A Átrica è um continente formado por 53 paises.

O continente africano é um dos maiores que há. Em tamanho, a África perde apenas pára a Ásia ea a América.

Na África, vivem 13 de cada 100 pessoas do mundo.

A partir destas pequenas informaçōes vou descrever a nossa atividade.

1-Cada aluno deverá escolher uma pessoa imaginaria, de um país da África para escrever uma carta.

- Na carta vocé o aluno deverá relatar a sua realidade e perguntar a essa "pessoa", como é a vida dela, como é a sua realidade. Assim, para cada experiência ou vivência relatada, o aluno deverá perguntar como acontece no outro pais.

3- A carta deverá ser colocada em um envelope e endereçada, com o nome do destinatário e o pais, além dos dados completos do remetente. 


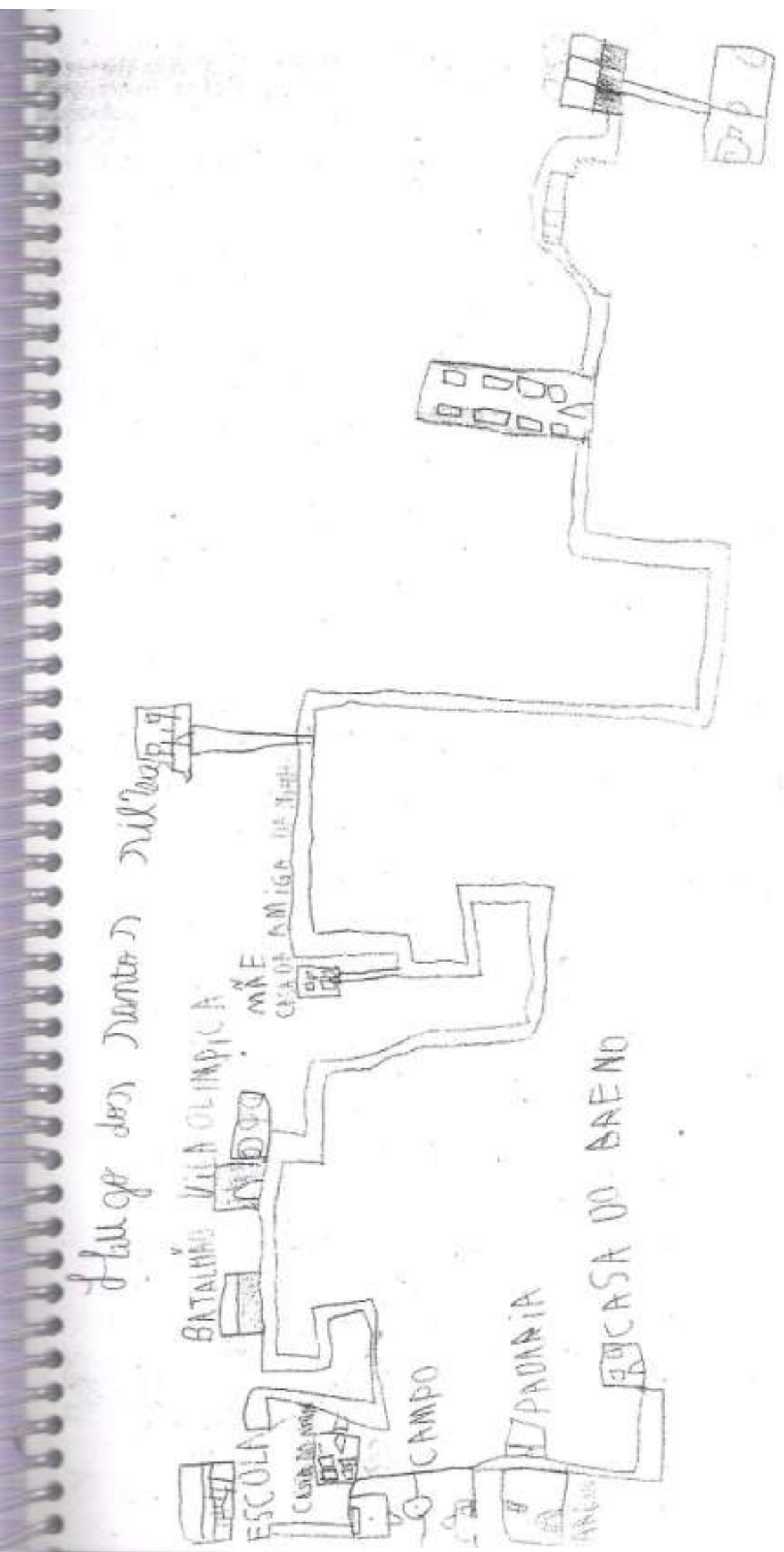




\section{MÁSCARAS}

\section{A máscara na África negra}

$\mathrm{Na}$ Africa, o artifice, antes de começar a esculpir uma máscara, passa por um processo de purificação, com reza aos espiritos ancestrais e às forças divinas. Tal prática faria com que a força divina fosse transferida para a máscara durante o processo de manufatura.

Se no passado era prática generalizada, o uso de máscaras rituais teve um enorme declínio nas últimas décadas. Entretanto, a manufatura e o emprego destes objetos continuam sendo um aspecto fundamental na identidade de vários grupos étnicos africanos. Por isso, já existem pessoas que trabalham pela preservaçẫo deste hábito milenar.

Principais funçōes de uma máscara:

- disfarce;

- simbolo de identificação;

- esconder a sua identidade;

- transfiguração;

- representação de espíritos da natureza, deuses, antepassados, seres sobrenaturais ou rosto de animais;

- participação em rituais (muitas vezes presente, porém sem utilização prática);

- interação com dança ou movimento;

- fundamental nas religiões animalistas;

- mero adereço;

- previnir contágios de outras pessoas

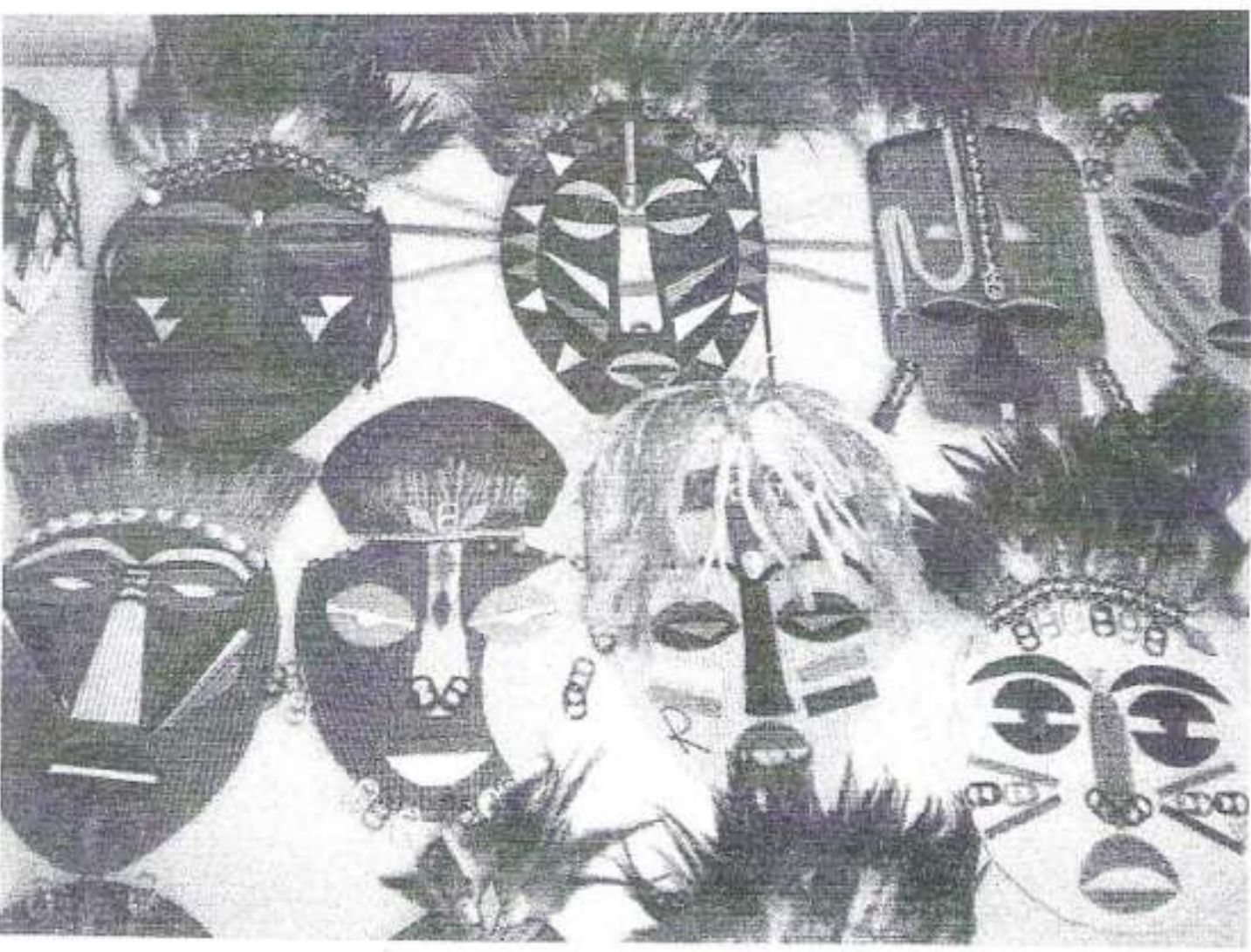




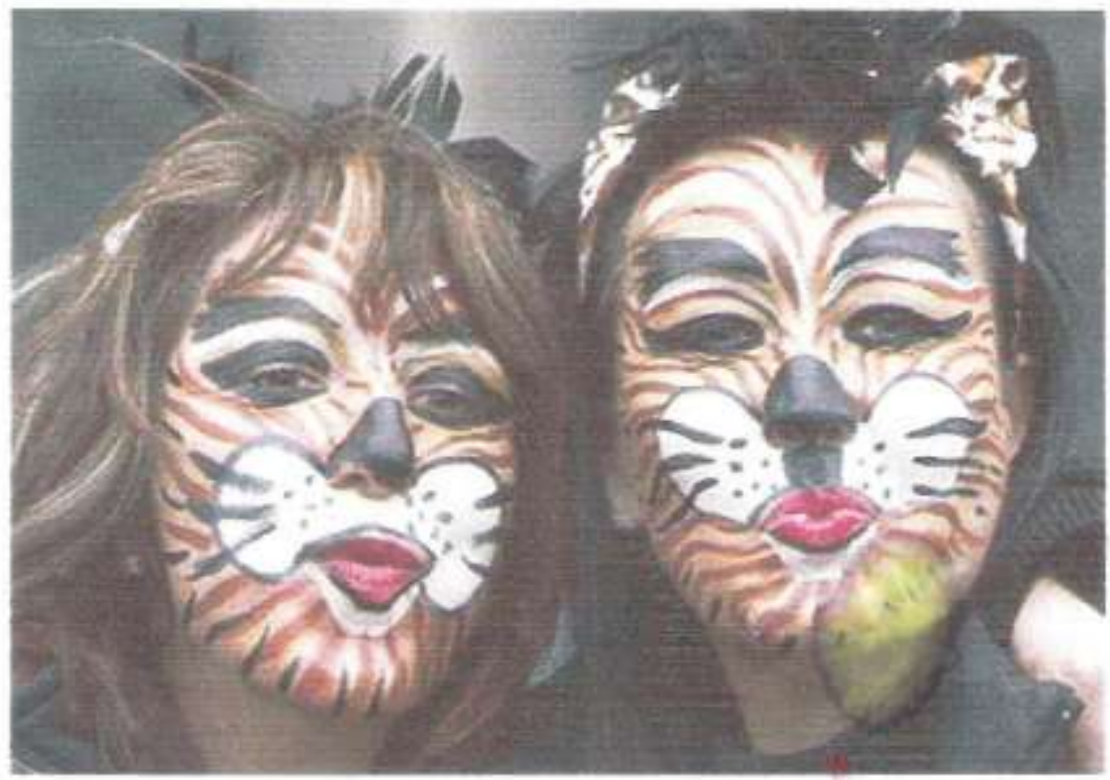

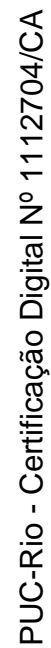
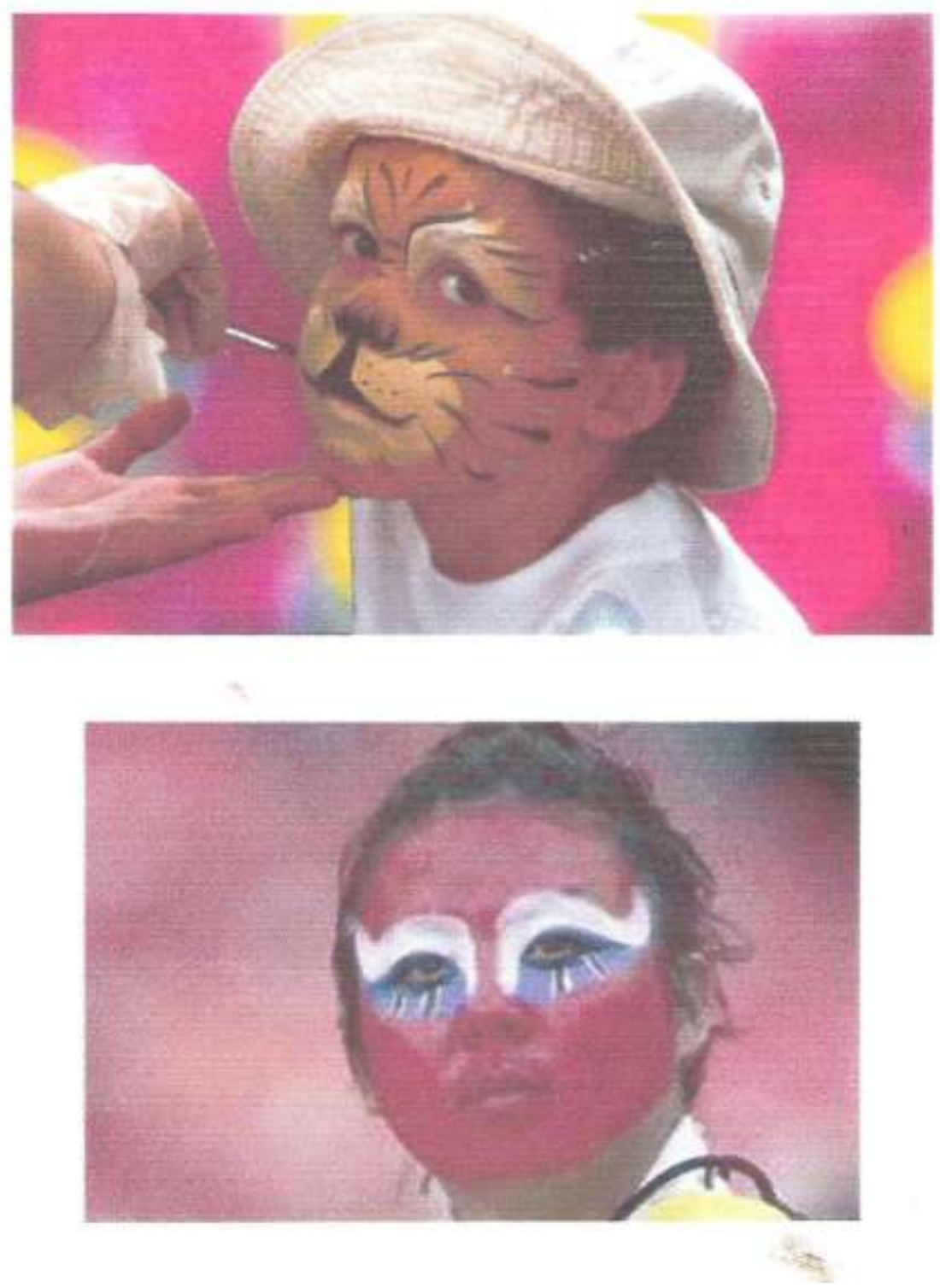


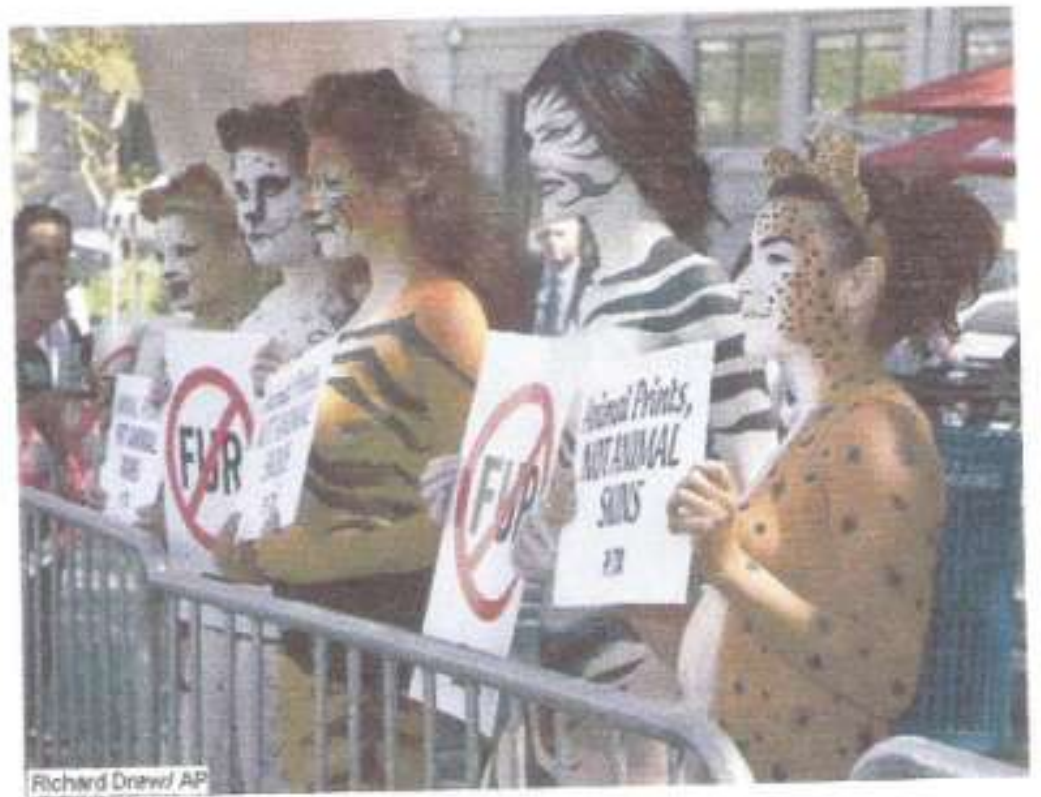

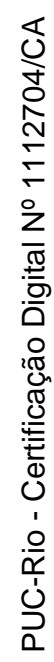
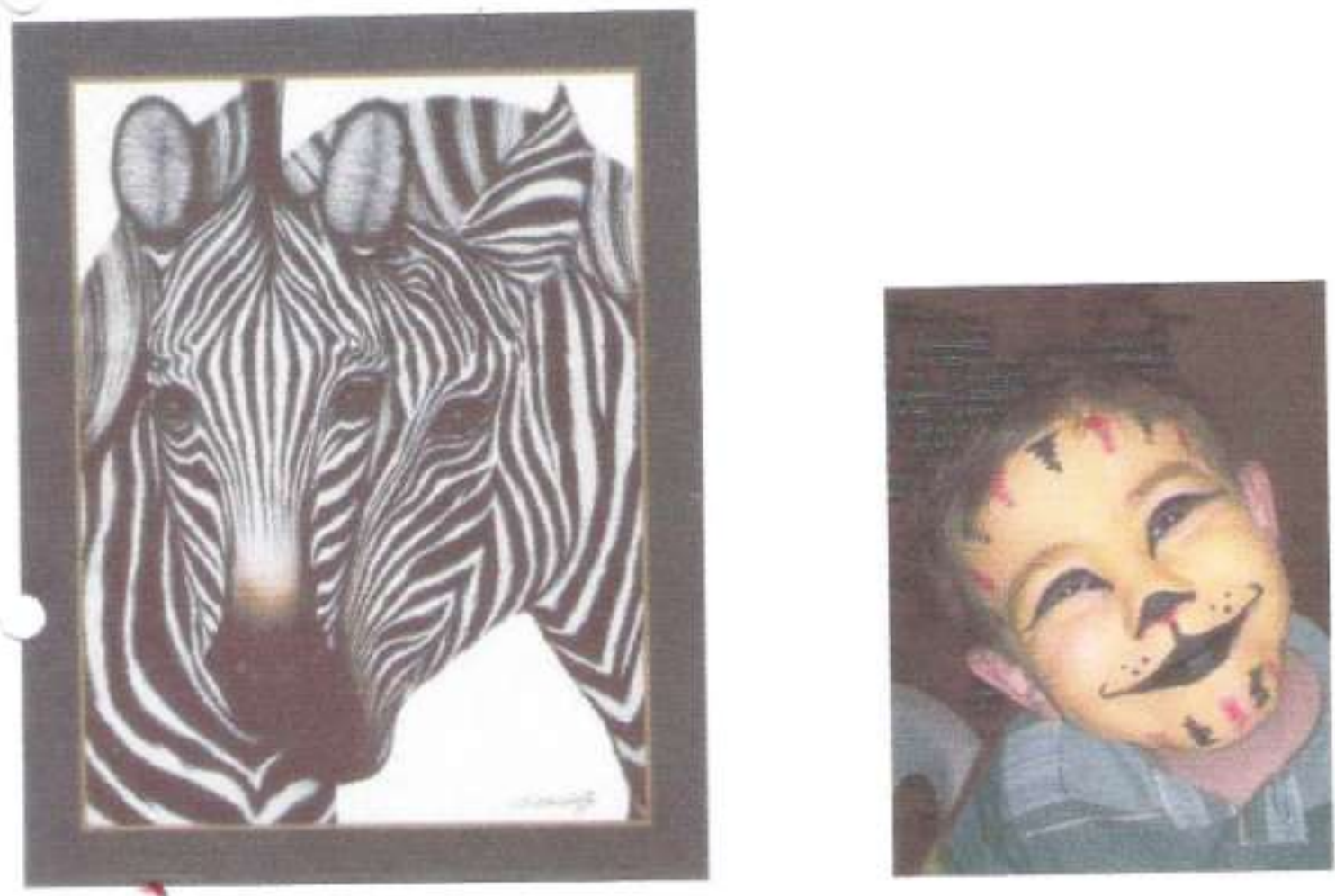


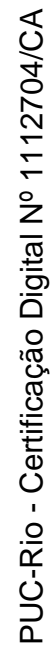
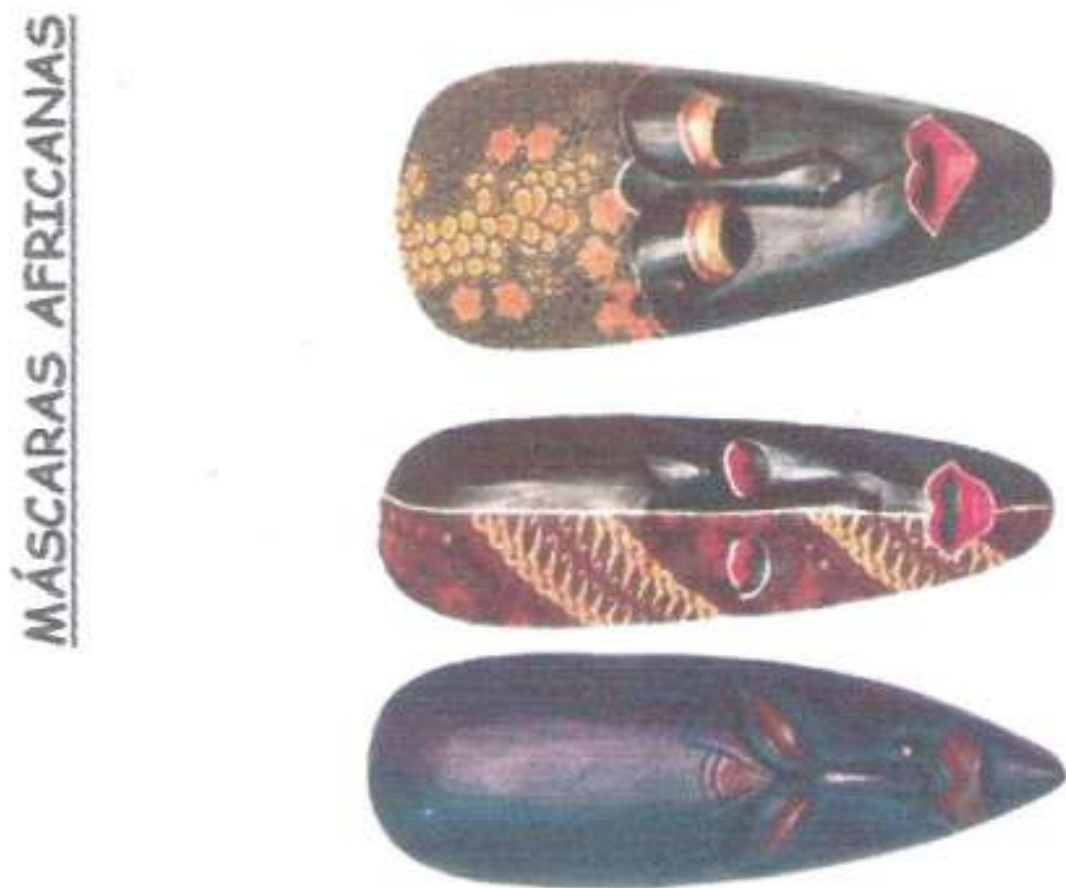


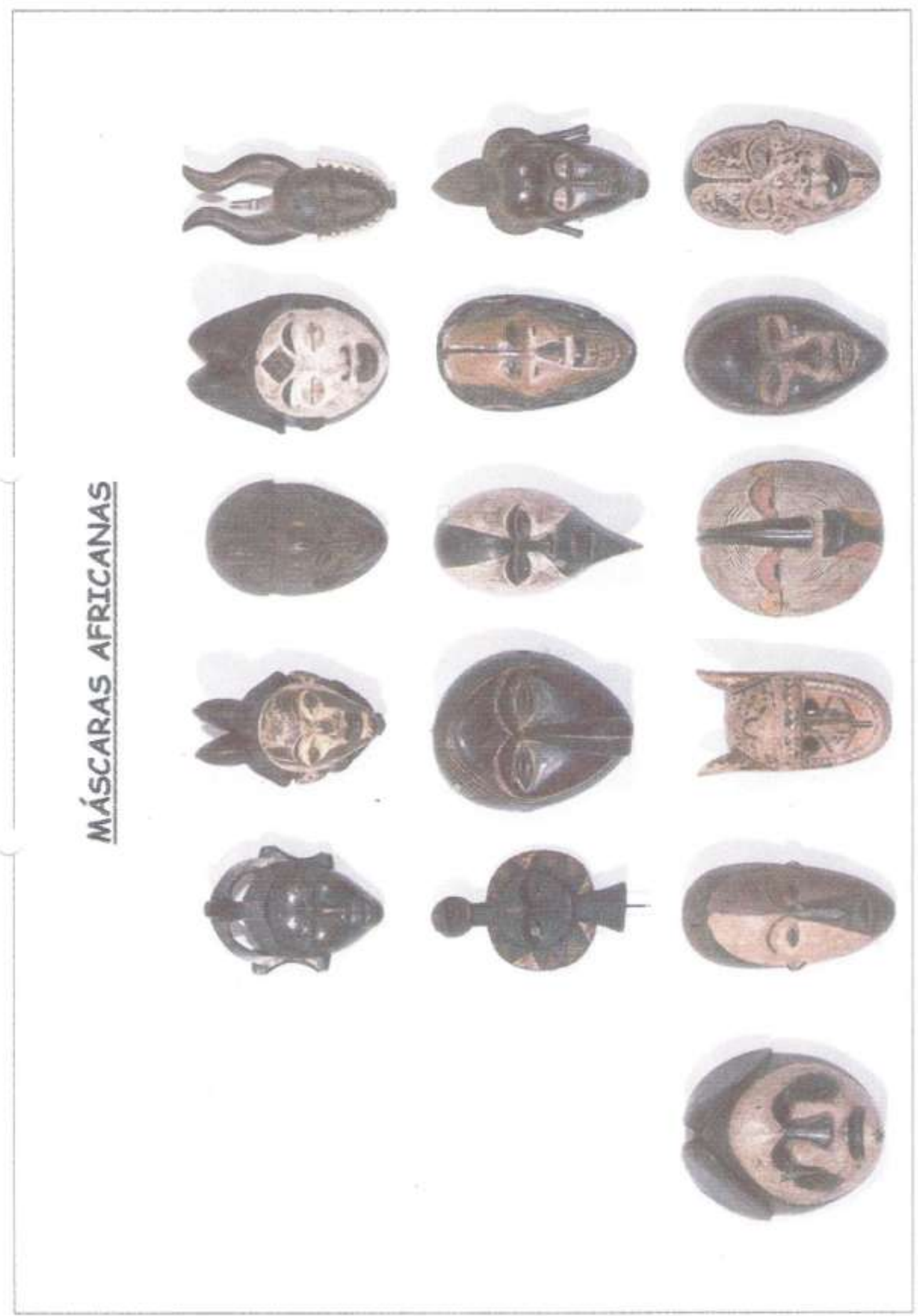




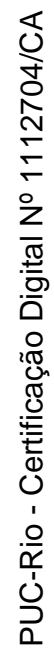
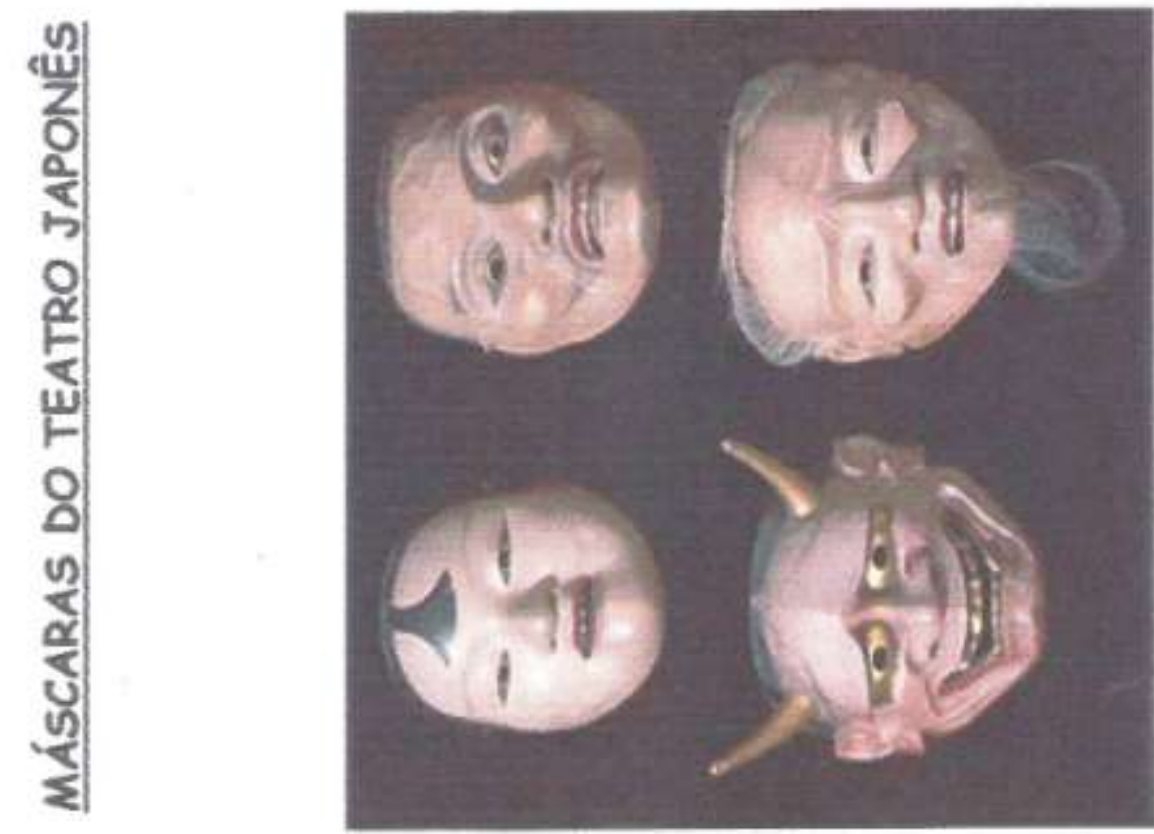


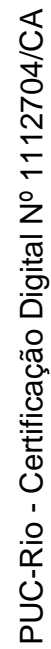
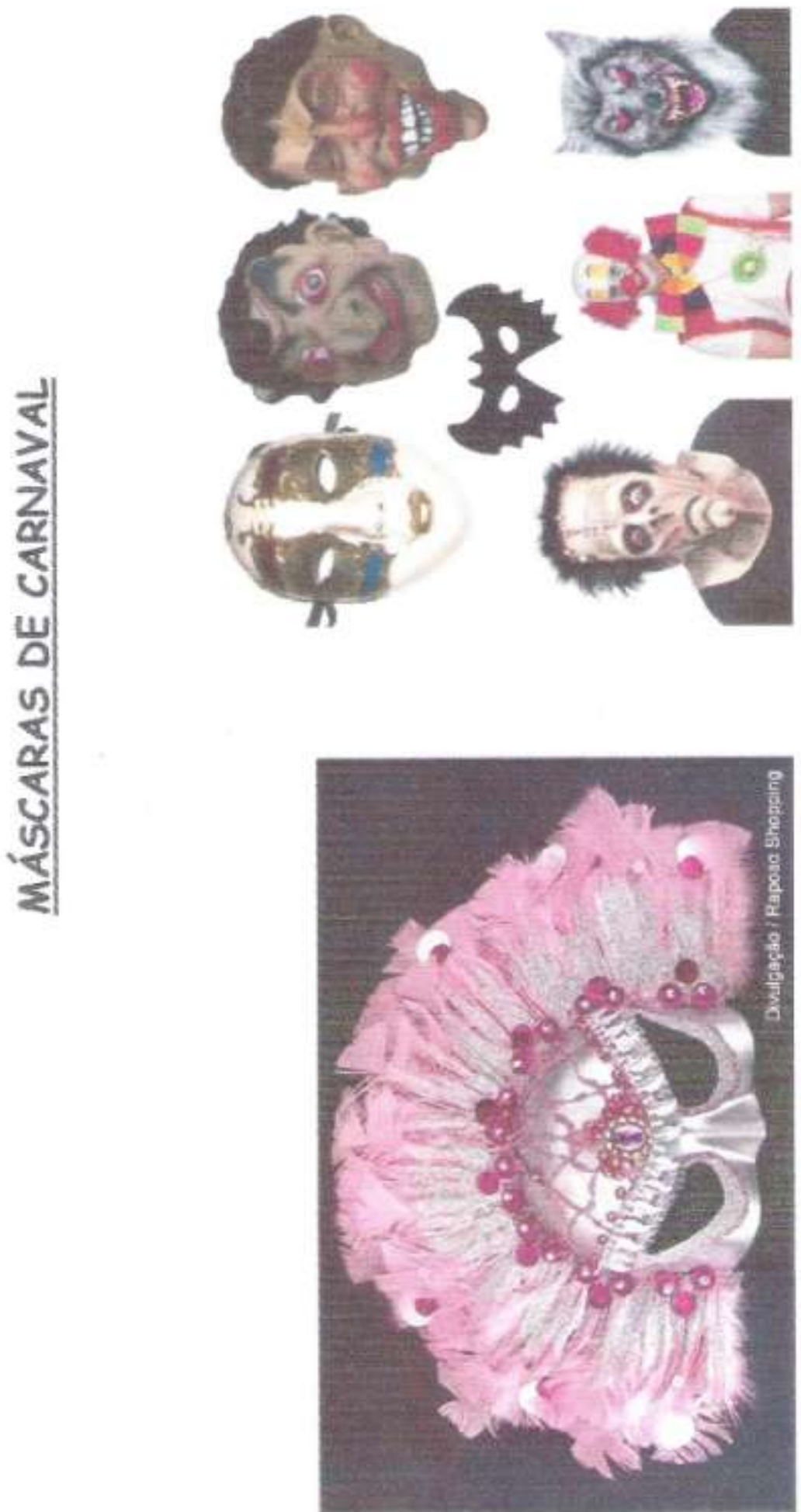


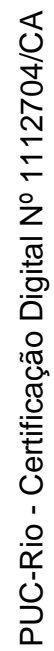

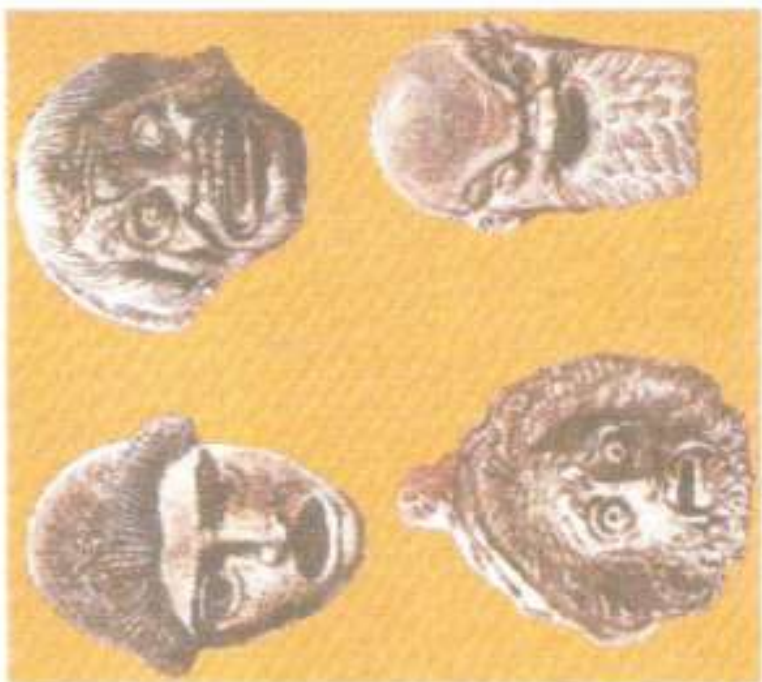

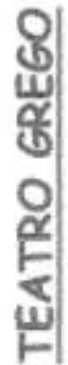
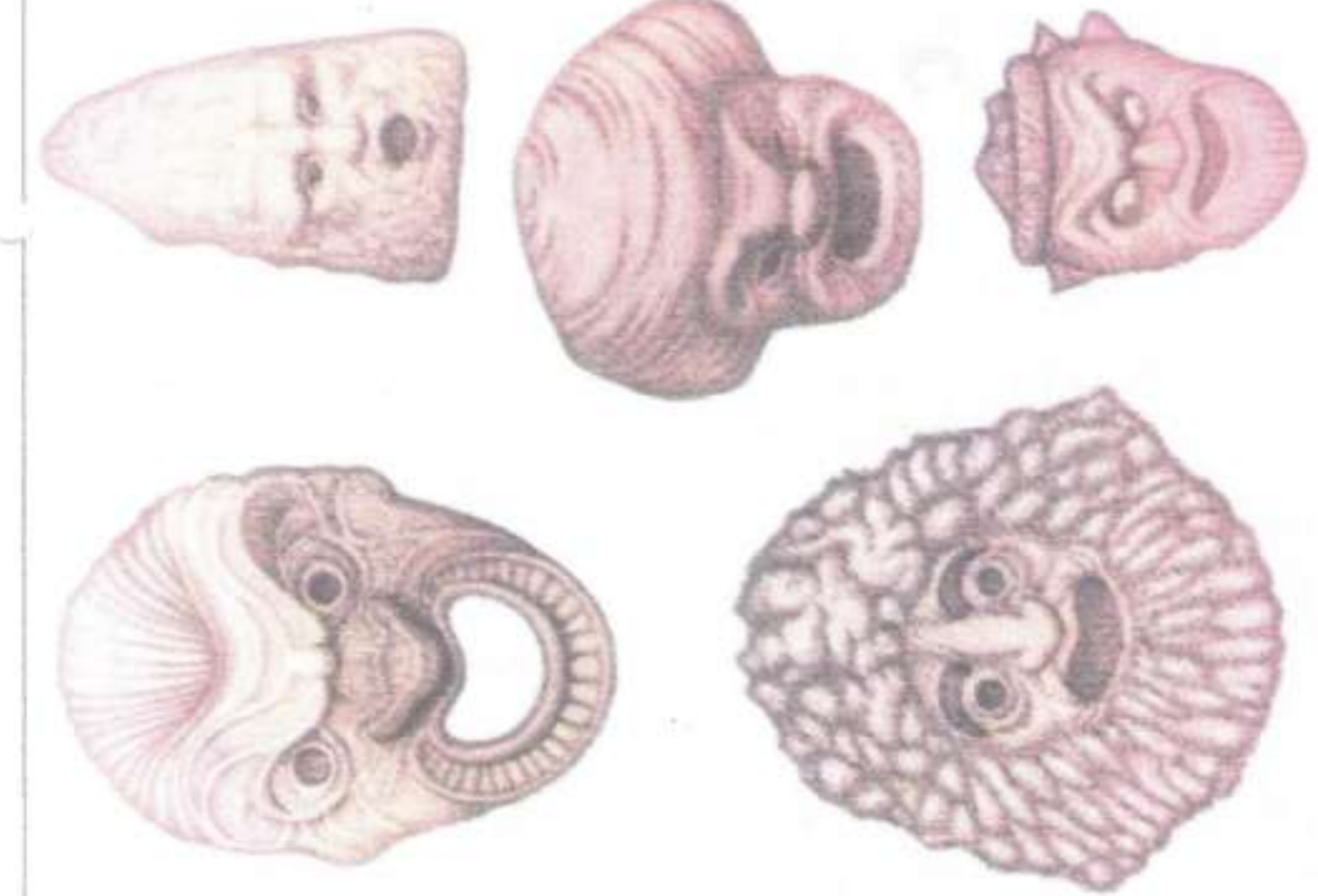


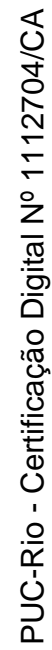
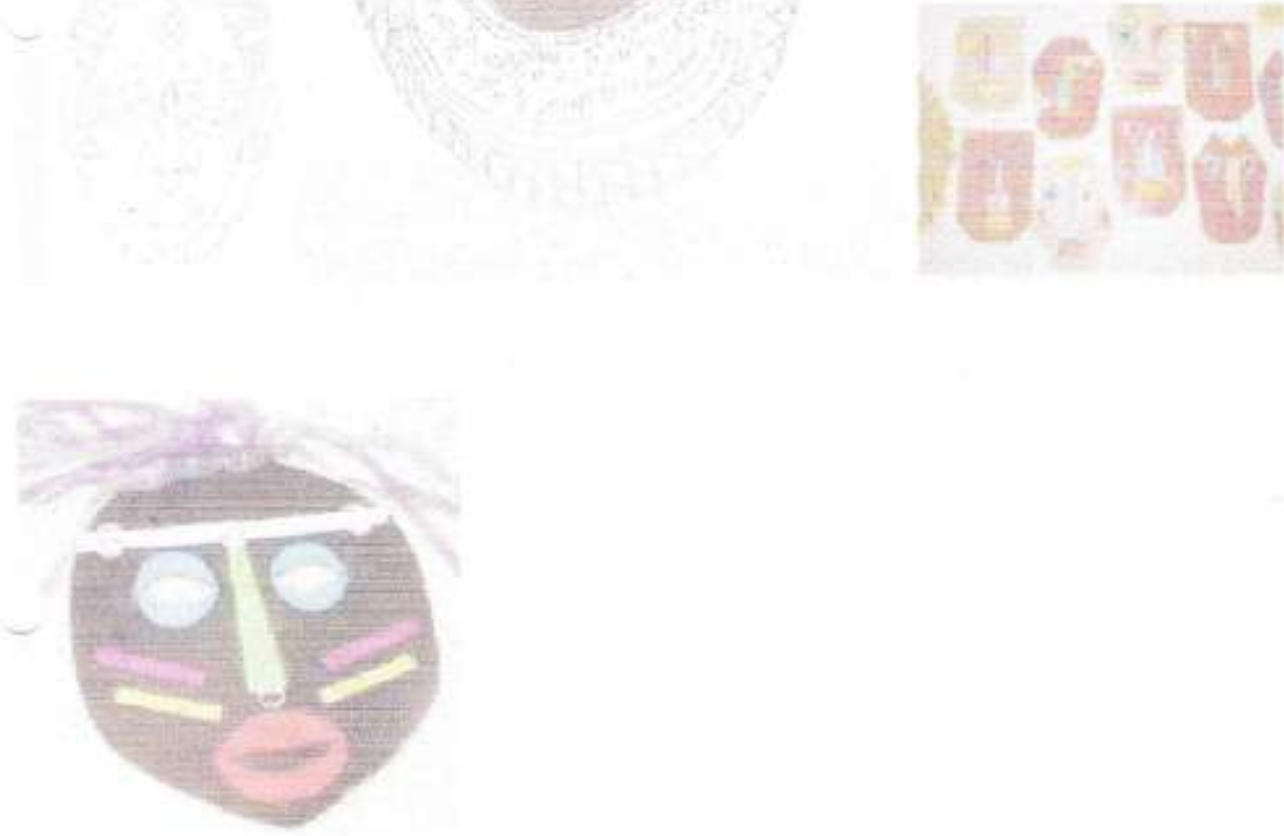
140

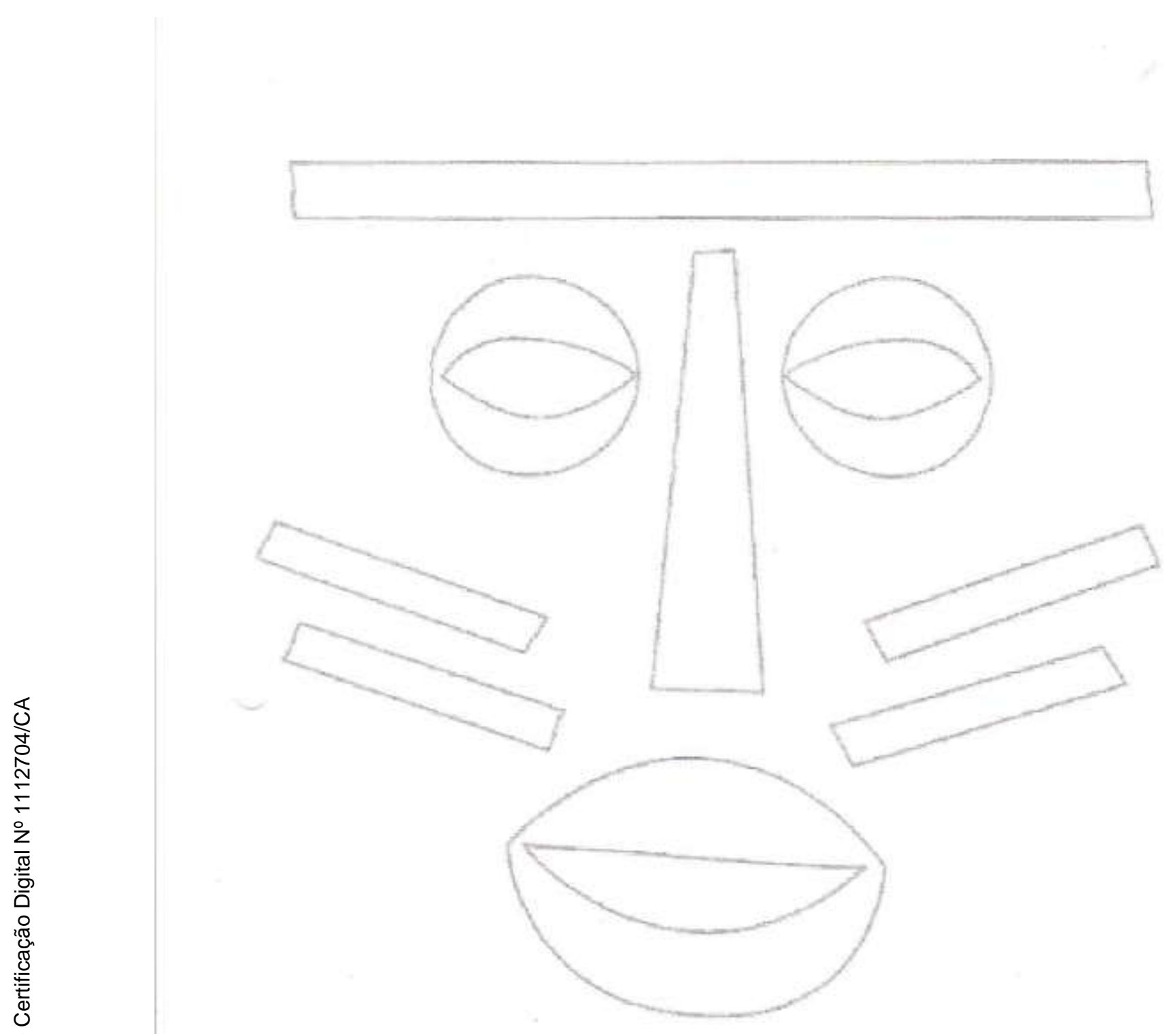




\section{EXPERIÊNCIAS NO LABIRINTO -}

Caminhando pela África

Maria Antonieta

Aluno (a): Data

Conhecendo seus ancestrais a partir do livro: "A África, meu pequeno Chaka..." de Marie Sellier e Marion Lesage.

Procure pela pessoa mais idosa da família, seu avô, por exemplo, e faça como - pequeno Chaka uma retrospectiva da história de sua família.

1. Conte, Vovô Dembo, quando você era pequeno, menor do que eu sou hoje.

2. Conte, Vovô Dembo, me conte também de sua Mamãe Kadidja.

3. Conte, Vovô Dembo, me conte do Papai Samba.

4. Conte, Vovô Dembo, me conte de Lawali-travesso, (amigo)

5. Conte, Vovô Dembo, me conte da sua aldeia.

6. Conte, Vovô Dembo, me conte o que você fazia durante o dia todo.

7. Conte, Vovô Dembo, me conte do festim de rei. (festa)

8. Conte, Vovô Dembo, me conte de quando você deixou de ser criança.

9. Conte, Vovô Dembo, me conte dos seus antepassados.

10. Conte, Vovô Dembo, me conte de seus planos. 


\section{TEMA: A MEMÓRIA DA LÍNGUA}

As palavras povoam nosso cotidiano, nossa história, nomeiam, significam a vida. Com o livro Memória das Palavras, vamos perceber o quanto falamos linguas africanas e o quanto sabiamos e não sabiamos da existência de palavras de origem africana no nosso cotidiano. Um dos nossos desejos é descobrir o que tem de africano em nós, na nossa familia, na nossa história, que marcas afro-brasileiras existem em nós, no nosso entorno.

Vamos à praia de tanga ou sunga, carregamos a canga na mochila, calçamos tamanco. Brincamos o carnaval da Bahia com abadá, ou dançamos samba com muita ginga, embalados pela cuica, agogô e ganzá. Comemos caruru e mocotó, botamos dendê no acarajé e no vatapá... Fumamos cachimbo, bebemos água de moringa, damos um pito, tomamos um gole de cachaça, usamos carimbo e năo gostamos de camundongo.
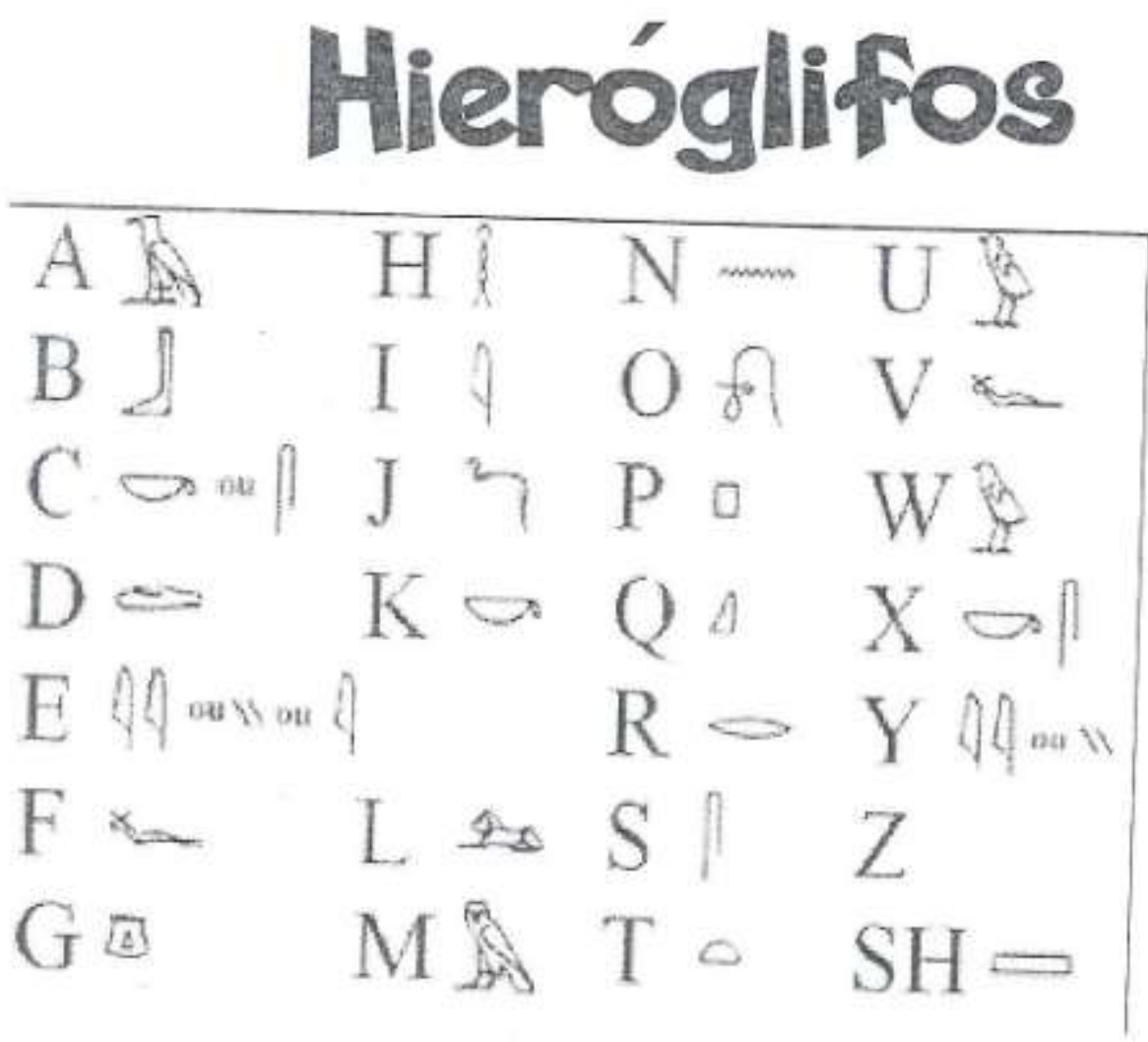


\title{
Vocabulário Africano
}

\author{
A \\ abará: bolinho de feijão. \\ acará: peixe de esqueleto ósseo. \\ acaraje: bolinho de feijāo frito (feijão fradinho). \\ agogố: instrumento musical constituido por uma dupla campânula de ferro, produzindo \\ dois sons. \\ angu: massa de farinha de trigo ou de mandioca ou arroz.
}

B

bangüê: padiola de cipós trançados na qual se leva o bagaço da cana.

bangulé: dança de negros ao som da puita, palma e sapateados.

banzar: meditar, matutar.

banzo: nostalgia mortal dos negros da África.

banto: nome do grupo de idiomas africanos em que a flexão se faz por prefixos.

batuque: dança com sapateados e palmas.

banguela: desdentado.

berimbau: instrumento de percussăo com o qual se acompanha a capoeira.

búzio: concha.

C

cachaça: aguardente.

cachimbo: aparelho para fumar.

cacimba: cova que recolhe água de terrenos pantanosos.

Caculé: cidade da Bahia.

cafife: diz-se de pessoa que dá azar.

cafuca: centro; esconderijo.

cafua: cova.

cafuche: irmão do Zumbi.

cafuchi: serra.

cafundó: lugar afastado, de acesso dificil.

cafuné: carinho.

cafungá: pastor de gado.

calombo: quisto, doença.

calumbá: planta.

calundu: mau humor.

camundongo: rato.

Candomblé: religião dos negros iorubás.

candonga: intriga, mexerico.

canjerê: feitiço, mandinga.

canjica: papa de milho verde ralado.

carimbo: instrumento de borracha.

catimbau: prática de feitiçaria .

catunda: sertão.

Cassangue: grupo de negros da África.

caxambu: grande tambor usado na dança harmônica.

caxumba: doença da glândula falias.

chuchu: fruto comestivel.

cubata: choça de pretos; senzala.

cumba: forte, valente.

Cumbe: povoaçăo em Angola.

D

dendê: fruto do dendezeiro. 
dengo: manha, birra.

diamba: maconha.

E efó: espécie de guisado de camarǒes e ervas, temperado com azeite de dendê e pimenta.

Exu: deus africano de potências contrárias ao homem.

$\mathrm{F}$

fubá: farinha de milho.

\section{G}

guandu: o mesmo que andu (fruto do anduzeiro), ou arbusto de flores amarelas, tipo de feijăo comestivel.

।

inhame: planta medicinal e alimenticia com raiz parecida com o cará.

lemanjá: deusa africana, a măe d' água dos iorubanos.

iorubano: habitante ou natural de loruba (Africa).

J

jeribata: alcóol; aguardente.

jeguedè: dança negra.

jiló: fruto verde de gosto amargo.

jongo: o mesmo que samba.

L

libambo: bébado (pessoas que se alteram por causa da bebida).

lundu: primitivamente dança africana.

M

macumba: religiăo afro-brasileira.

máculo: nódoa, mancha.

malungo: titulo que os escravos africanos davam aos que tinham vindo no mesmo

navio; irmão de criação.

maracatu: cortejo carnavalesco que segue uma mulher que num bastăo leva uma bonequinha enfeitada, a calunga.

marimba: peixe do mar.

marimbondo: o mesmo que vespa.

maxixe: fruto verde.

miçanga: conchas de vidro, variadas e miúdas.

milonga: certa música ao som de violão.

mandinga: feitiçaria, bruxaria.

molambo: pedaço de pano molhado.

mocambo: habitação muito pobre.

moleque: negrinho, menino de pouca idade.

muamba: contrabando.

mucama: escrava negra especial.

mulunga: árvore.

munguzá: iguaria feita de grăos de milho cozido, em caldo açucarado, às vezes com leite de coco ou de gado. O mesmo que canjica.

murundu1: montanha ou monte; monticulo; o mesmo que montâo.

mutamba: árvore.

muxiba: carne magra.

muxinga: açoite; bordoada. 
muxongo: beijo; caricia.

maassagana: confluência, junçăo de rios em Angola.

O

Ogum ou Ogundelê: Deus das lutas e das guerras.

Orixá: divindade secundário do culto jejênago, medianeira que transmite súplicas dos devotos suprema divindade desse cuito, idolo africano

P

puita: corpo pesado usado nas embarcaçōes de pesca em vez fateixa.

Q

quenga: vasilha feita da metade do coco.

quiabo: fruto de forma piramidal, verde e peludo.

quibebe: papa de abóbora ou de banana.

quilombo: valhacouto de escravos fugidos.

qui 10: invocado nas cantigas de ninar, o mesmo que cuca, festa dançante dos

negrus.

queimana: iguaria nordestina feita de gergelim

quimbebé: bebida de milho fermentado.

quimbembe: casa rústica, rancho de palha.

quimgombo̊: quiabo.

quitute: comida fina, iguaria delicada.

quizilia: antipatia ou aborrecimento.

S

samba: dança cantada de origem africana de compasso binário ( da lingua de Luanda, semba $=$ umbigada).

senzala: alojamento dos escravos.

soba: chefe de trigo africana.

T

tanga: pano que cobre desde o ventre até as coxas.

tutu: iguaria de carne de porco salgada, toicinho, feijâo e farinha de mandioca.

U

urucungo: instrumento musical.

$\checkmark$

vatapá: comida.

$x$

xendengue: magro, franzino

Z

zambi ou zambeta: cambaio, torto das pernas.

zumbi: fantasmas. 


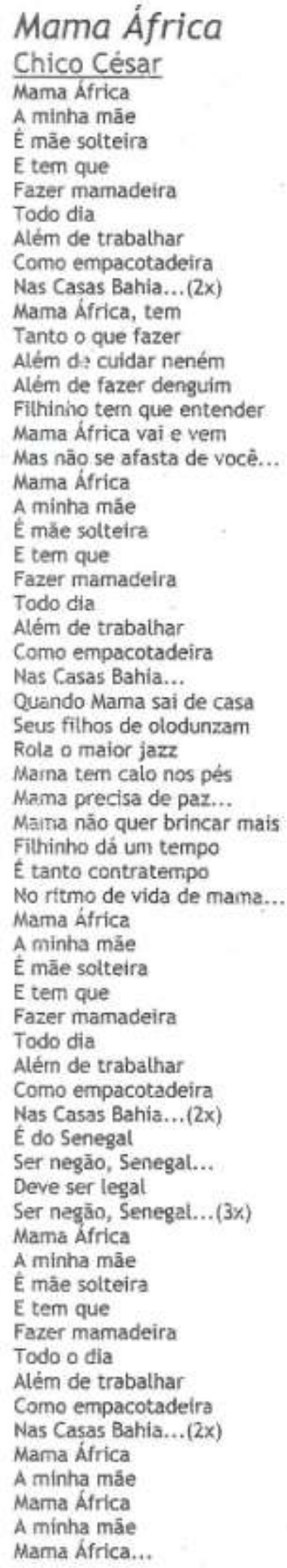

\section{Dandalunda Margareth Menezes}

Composicto : Cartinhos Brown / Refrẩ Excraido Do Domínio Púbtico Bem pertinho da entrada do gueto

Um terreiro de Angola e Ketu

Măe maiamba que comanda o centro

Dona Oxúm dançando Oxóssi no tempo

Lả em cima no tamarineiro

Marinha da pipoca ajoetha

Em janeiro, no dia primeiro

Desce o dono do terreiro

Coquê

Dandalunda, maimbanda, coquê $(4 X)$

Seu zumbi é santo sim que eu sel

Caxixi, agdavi, capoetra

Casa de batuque e toque na mesa

Linda santa lansã da pureza

Vira fogo, atraca, atraca, se chegue

Vi Nană clentro da mata do jejê

Brasa acesa na pisada do frevo

Arrepia o corpo inteiro

Coquê dandalunda maimbanda.

Coqué

Dandatunda

Paira na beira

Dandalunda

Da cahoeira

Dandalunda

Paz e água fresca

Dandalunda

Doura dendê 


\section{Jogo da Memória - Experiências no Labirinto}

1) Nossa oficina tem por objetivo conhecer nossa identidade afro - brasileira. $O$ titulo dela é:

a) Cultura afro-brasileira

b) África - um safári

c) Experiências no labirinto

2) Usar histórias que se passaram num labirinto que é um lugar dificil de sair, misterioso e por vezes assustador pode ser interpretado como:

a) Uma caverna escura

b) Uma busca interior ( personalidade ) vida

c) Uma lenda de um rei

3) Na África, era usada nos rituais para esconder a identidade, um modo de disfarçar as pessoas . Que objeto era esse?
a) Máscara
b) Cachimbo
c) Espiritos

4) As principais funçōes de uma máscara sāo:

a) Confeccionadas em barro, madeira ou metais

b) Disfarce, transfiguraçẫo, adereço / enfeite

c) Mágica, dança sagrada, identidade

5) "A África, meu pequeno Chaka ... " livro lido em uma das oficinas tinha por personagens centrais o avô e o menino cujas nomes eram respectivamente :

a) Mamãe Kadidja e Papai Samba

b) Lavall - travesso e vovô Dembo

c) Vovô Dembo e o pequeno Chaka 
(3) Deusa africana, conhecida como mãe da água é :
a) lemanjá
b) Exu
c) Olodum

7) O primeiro alfabeto que deu inicio ao nosso era composto de:
a) miçangas
b) hieróglifos
c) simbolos indigenas

8) Os filmes que assistimos se passavam na África em uma tribo. Os personagens principais eram :
a) Karabá e Kiriku
b) kadidja e Vovô Sábio
c) Zumbi e Kiriku
9) Boa parte do que foi escrito e lido por nós sobre os povos africanos foi contado por viajantes missionários e comerciantes europeus. Só muito recentemente a história da África foi contada por africanos. Ficamos com a interpretação errada, parcial e confusa contada pelos:

a) Escravos

b) Senhores de engenho

c) Brancos " colonizadores"

10) Os primeiros grupos humanos que temos notícia surgiram no continente :
a) Africano
b) Americanos
c) Europeu 
11) Contamos com muitas palavras africanas em nosso cotidiano. Qual opção as palavras são todas de origem africana?

a) Mamadeira, mãe, empacotadeira

b) Dendê, neném, solteira

c) agogô, berimbau, Oxossi

12) Fizemos um safári pela África e os animais que encontramos lá foram :

a) Zebra, elefante, girafa

b) Vaca, macaco, elefante

c) Zebra, cavalo, leão

13) Sabemos que na África tem paises que falam o português como nós. Um deles é :

a) África do Sul

b) Angola

c) Camaröes

14) Fizemos um passeio a uma biblioteca estadual chamada:

a) Olavo Bilac

b) Zumbi

c) Manguinhos

(3) 15) A memória da África marcaria para sempre a nossa musicalidade. O ritmo que nós exportamos para o mundo todo trazido pelo africanos foi :
a) Jongo
b) Samba
c) Jazz 
16) Há muitos jogadores de futebol negros. O mais famoso é conhecido como rei é :
a) Ronaldinho Gaúcho
b) Pelé
c) Ramires

17) Instrumentos de origem africana que entram na percussăo, trazidos pela Clarete:
a) Violão e berimbau
b) Flauta e trompete
c) Atabaque e agogô

(3) 18) Não é só de samba, Carnaval, Maracatu e Afoxé que é feita a cultura afro-brasileira. Fazem parte dessa cultura também :
a) Bossa nova e axé
b) Capoeira e jongo ( desafio, charada )
c) Jazz e Blues

19) Para algumas tribos africanas a cultura oral era a única fonte histórica da sua origem. Quem era o guardiăo da sabedoria do povo de Kiruku?
a) 0 avô
b) A må̀e
c) Kiruku

20) Karabá tinha medo que retirassem o espinho que foi colocado em sua coluna vertebral. 0 que o espinho representava ?
a) Poder e maldade
b) Dor e poder
c) Amor e poder 


\section{UBUNTU}

A jornalista e filósofa Lia Diskin, no Festival Mundial da Paz, em Floripa (2006), nos presenteou com um caso de uma tribo na África chamada Ubuntu.

Ela contou que um antropólogo estava estudando os usos e costumes da tribo e, quando terminou seu trabalho, teve que esperar pelo transporte que o levaria até o aeroporto de volta pra casa. Sobrava muito tempo, mas ele não queria catequizar os membros da tribo; entâo, propôs uma brincadeira pras crianças, que achou ser inofensiva.

Comprou uma porção de doces e guloseimas na cidade, botou tudo num cesto bem bonito com laço de fita e tudo e colocou debaixo de uma árvore. Af ele chamou as crianças e combinou que quando ele dissesse "jú!". clas deveriam sair correndo até o cesto, e a que chegasse primeiro ganharia todos os doces que estavam lá dentro.

As crianças se posicionaram na linha demarcatória que ele desenhou no chão e esperaram pelo sinal combinado. Quando ele disse "Já!". instantancamente todas as crianças se deram as mãos c saíram correndo en direçtầ à árvore com o cesto. Chegando lá, começaram a distribuir os doces entre si e a comerem felizes.

O antropólogo foi ao encontro delas e perguntou porque elas tinham ido todas juntas se uma só poderia ficar com tudo que havia no cesto e, assim. ganhar muito mais doces.

Elas simplesmente responderam: "Ubuntu, tio. Como uma de nós poderia ficar feliz se todas as outras estivessem tristes?"

Ele ficou desconcertado! Meses e meses trabalhando nisso, estudando a tribo, e ainda não havia compreendido, de verdade, a essẻncia daquele povo. Ou jamais teria proposto uma competição, certo?

Ubuntu significa: "Son quem sou, porq̣ue somos todos nós!" 


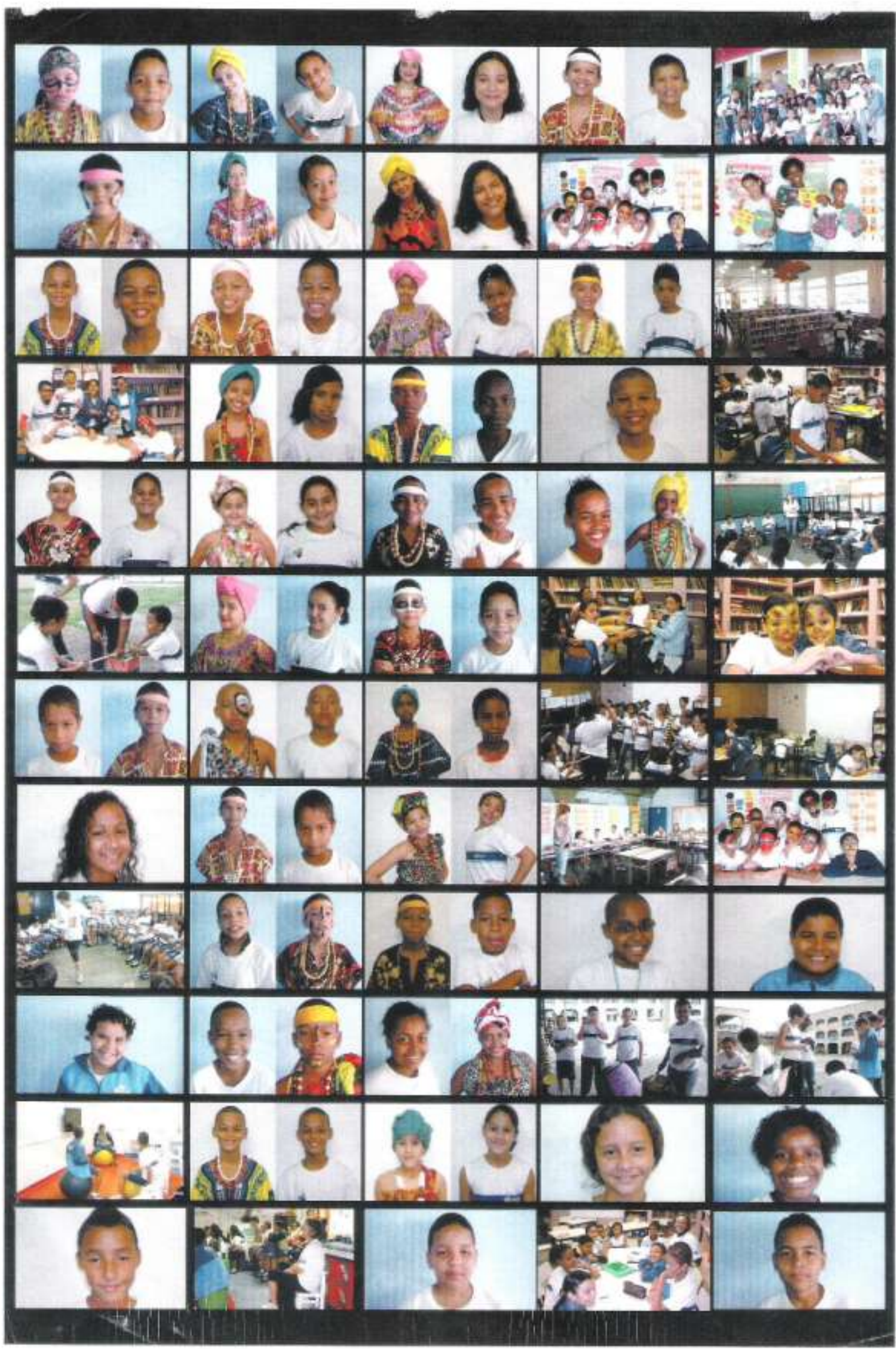


7.2

Literatura em Rede (2012)

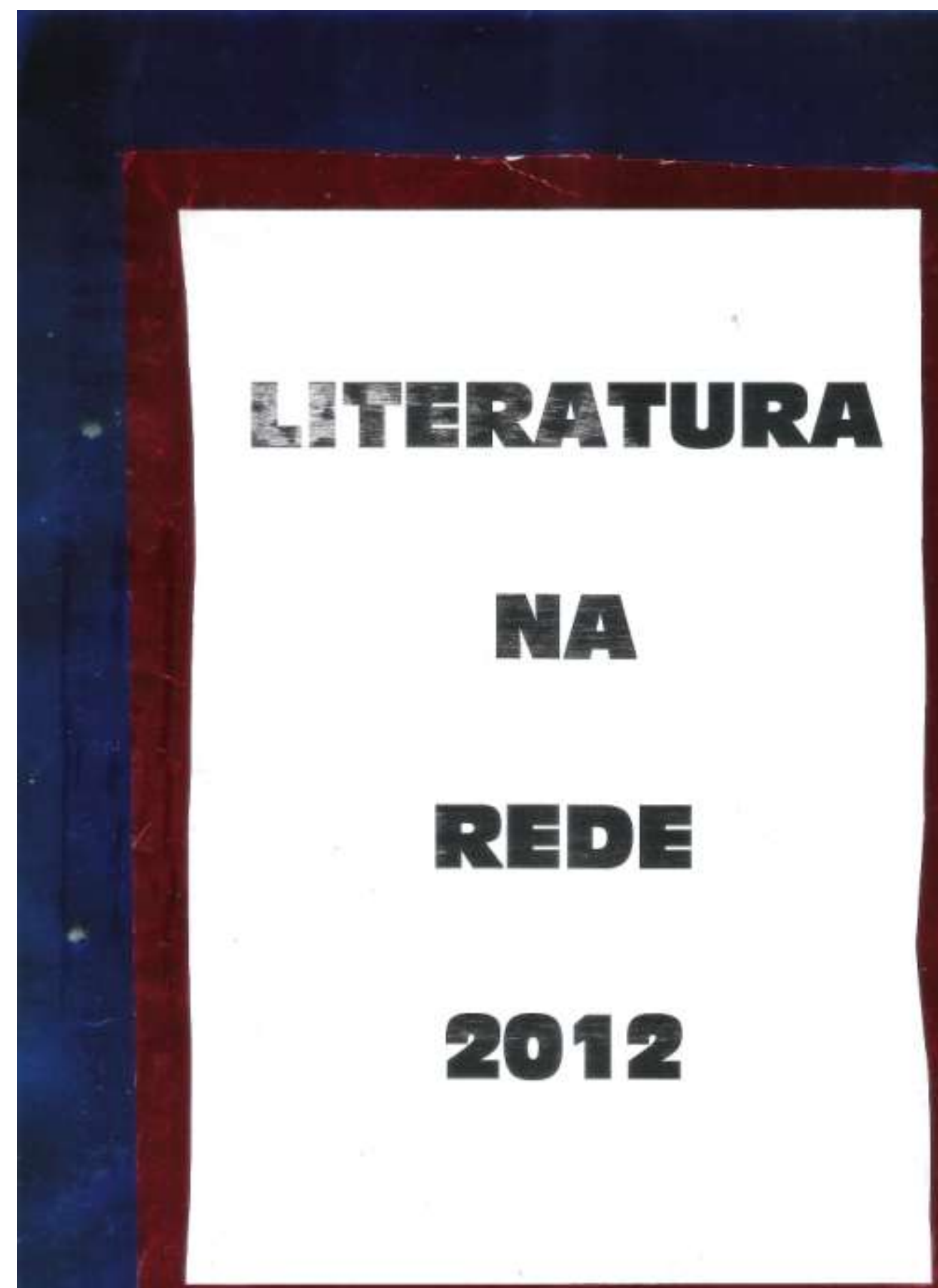




\title{
I SEMINÁRIO INTERNACIONAL DE ARTE-EDUCAÇÃO FÓRUM DE EXPERIÊNCTAS DO SEGUNDO TURNO CULTURAL
}

\author{
Oficina: LITERATURA NA REDE \\ Dinamizadora: Maria Antonieta Sampaio Rodrigues
}

Sou dinamizadora de oficina de literatura nas escolas Chanceler Willy Brandt, Coronel Sarmento e Teotônio Vilela. Gosto muito de usar a metáfora do labirinto como ícone do meu trabalho por simbolizar complexidade e desafio. O labirinto da oficina vai sendo construido em nossos encontros semanais de 2 horas de duração com atividades lúdicas, dinâmicas onde o final tenha um caráter "imprevisivel" $\mathrm{e}$ instigante como na tensẫo da lenda do Minotauro. A oficina desafia os alunos a participarem das narrativas.

No ano passado trabalhei o aspecto labirintico da formação da identidade brasileira considerando as contribuiçøes africanas para nossa cultura. Nomeei a oficina de Experiências no Labirinto e na mostra no teatro Carlos Gomes, os trabalhos realizados foram expostos na forma de labirinto.

Este ano, o labirinto está sendo criado a partir principalmente da obra da escritora e ilustradora Ângela Lago, que desafia o leitor para um jogo textual no qual tanto a linguagem gráfica quanto a escrita são utilizadas de forma pouco convencional. Ela cria uma estrutura que permite, durante a leitura, a produção de várias interpretaçôes. Se o leitor aceita o desafio de entrar no labirinto de suas obras, penetrará num lugar em que a subversāo das regras faz parte do jogo, qualquer coisa pode ser tudo: as paredes, os caminhos, nada é definitivo, sendo construido ou reconstruido pelo leitor à medida que ele avança no labirinto, na sua busca. (André Mendes, O amor e o diabo em Ângela Lago, p.15).

Para o mundo ficcional existir, é necessário haver um leitor que reconheça os códigos utilizados, que tenha expectativas culturalmente determinadas. Minha oficina busca através da literatura apresentar de forma sempre lúdica, os significados $\mathrm{c}$ significantes contidos nos textos artísticos em suas mais variadas linguagens.

No labirinto da leitura, firma-se um pacto no qual as regras podem ser subvertidas, onde nada é definitivo, o labirinto vai sendo construido e reconstruido pelo leitor à medida que avança na sua busca através do objeto artístico. A leitura entendida como um processo ativo de reescrita se torna acessivel para os participantes, que estiverem dispostos a interpretar seus significados e estabelecerem uma experiência de fruição, ou seja, alguma relação de prazer a partir do contato com os textos, sejam eles digitais ou através dos livros convencionais.

\section{ATIVIDADES DESENVOLVIDAS:}

1. Potencializar o lúdico e o imaginário, sem permanecer somente na superficie das imagens.

2. Proporcionar espaços ficcionais e efetivos de leitura.

3. Estimular as trocas, as intertextualidades e os dialogismos e, com isso, socializar o entendimento.

4. Trabalhar com múltiplas linguagens instigando a capacidade de estabelecer analogias entre os vários sistemas de linguagem. 
5. Envolver os alunos em práticas que sejam significativas para o entendimento dos textos e que façam ou construam sentido(s) para sua própria realidade.

\section{PROPOSTA DE TRABALHO}

Montar um e-book com textos narrativos e poesia, escrito e ilustrado pelos alunos, tendo como norteadora, a escritora e ilustradora Ângela Lago.

DEFINIÇÃO DE ÂNGELA LAGO SOBRE E-BOOK

"A possibilidade de leitura não linear e o recurso de códigos simultâneos estão explodindo numa nova revolução da comunicação, que ainda não podemos avaliar. Apenas começamos a compreender que a descentralização do olhar que acontece na Internet é resultado de uma nova leitura do mundo. (...) Todo o século XX se dedicou a procurar novas perspectivas, novas maneiras de olhar o mundo que não a fotográfica, como num prenúncio da era digital. (...) A tridimensionalidade do espaço virtual, o tempo simultâneo, a transparência no desenho dos micros e macros universos, são veios de uma nova possibilidade de enxergar o mundo. Um mundo não linear.

As crianças parecem à vontade com esses veios. Talvez os artistas mais uma vez as acompanhem."

Exemplos:

1. Dinâmica com poesia - poemas escaneados com ilustração

2. Conto - Encurtando o caminho com ilustrações

3. Roda de leitura das obras de Ângela Lago

4. Textos escritos e ilustrados pelos alunos

5. Minha foto com a autora escolhida

6. Site Ângela Lago

7. Curta com Ângela Lago do Itaú Cultural 


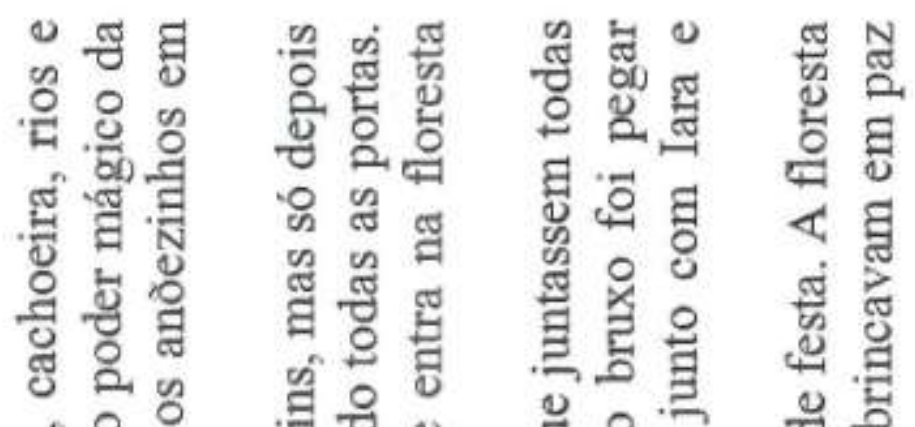

艎

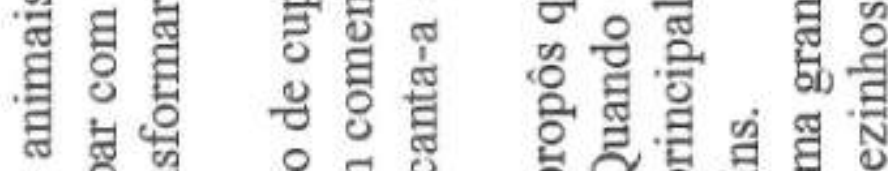

ข

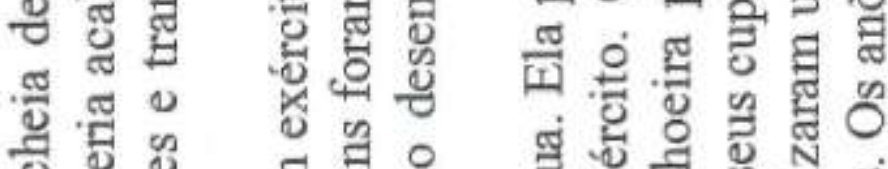

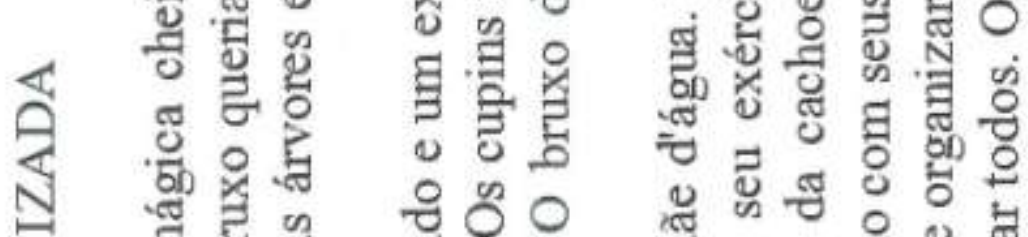

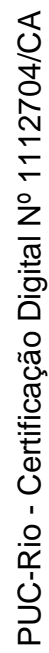

ఫ్తిర

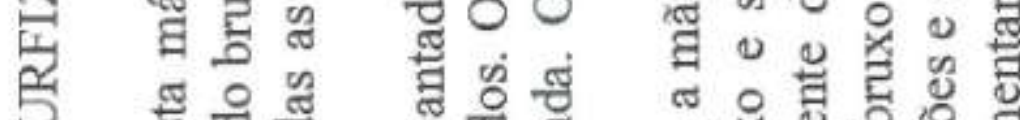

卢 ॠ

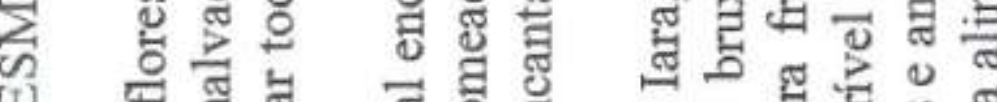

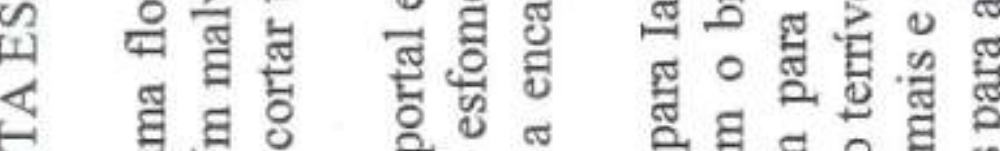

थ

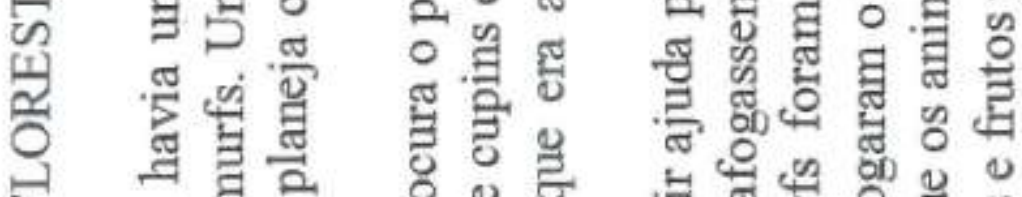

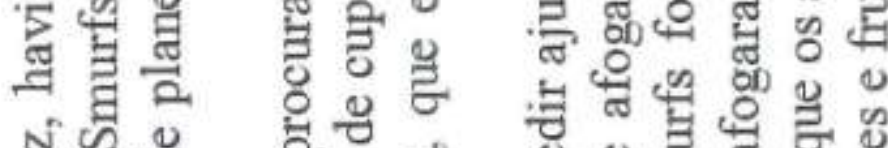

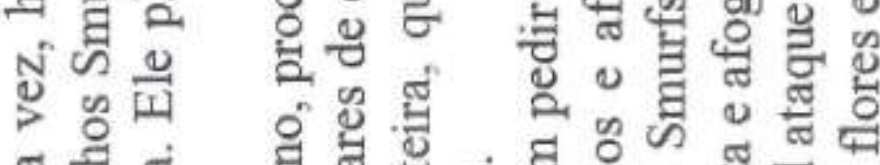

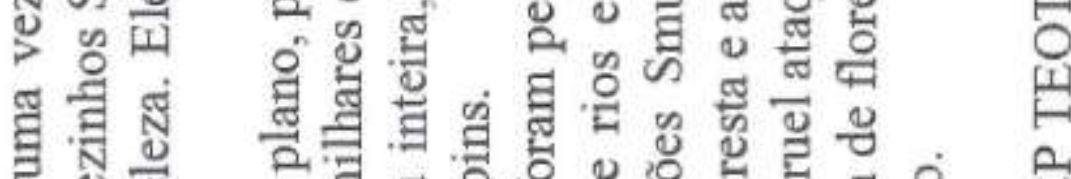

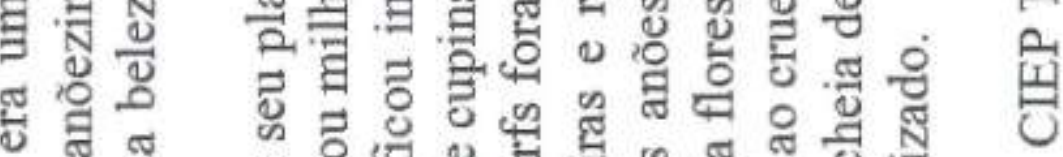

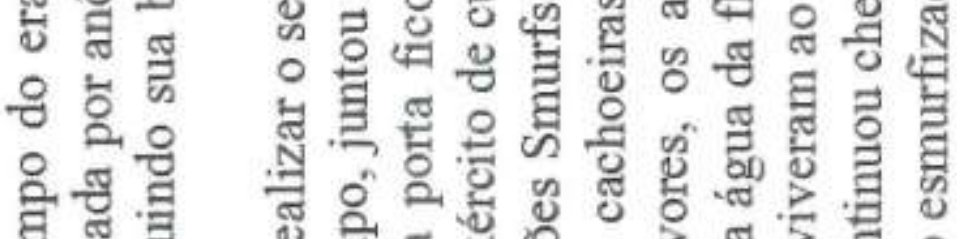

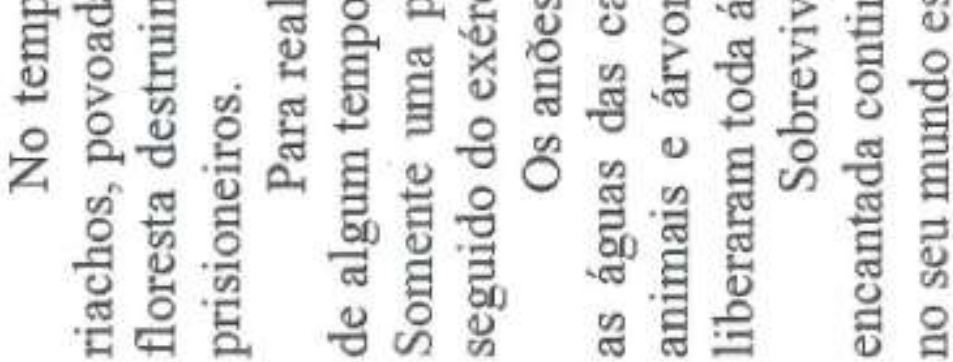

 


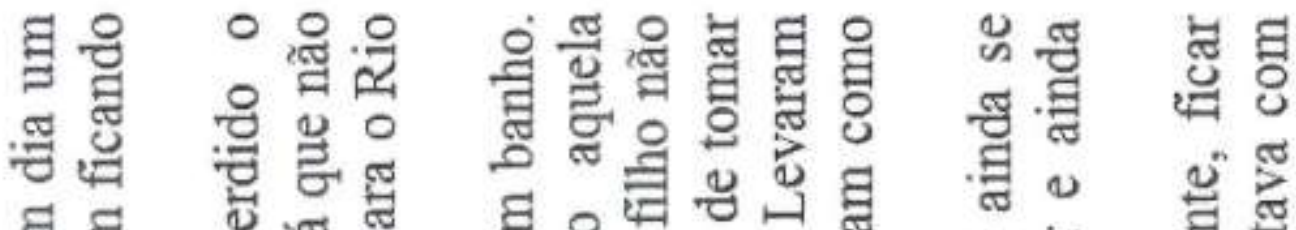

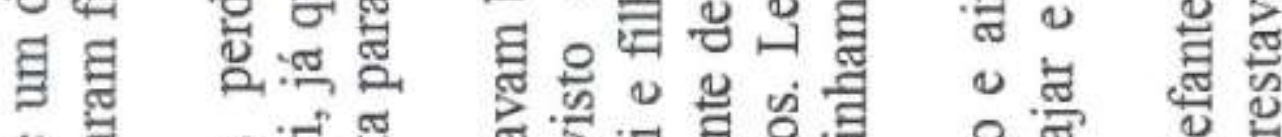

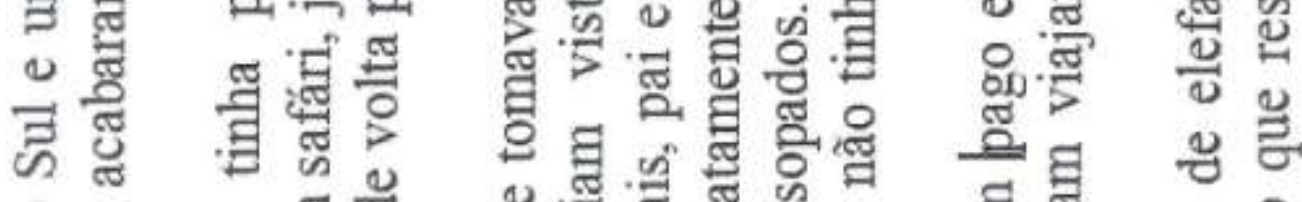
๖

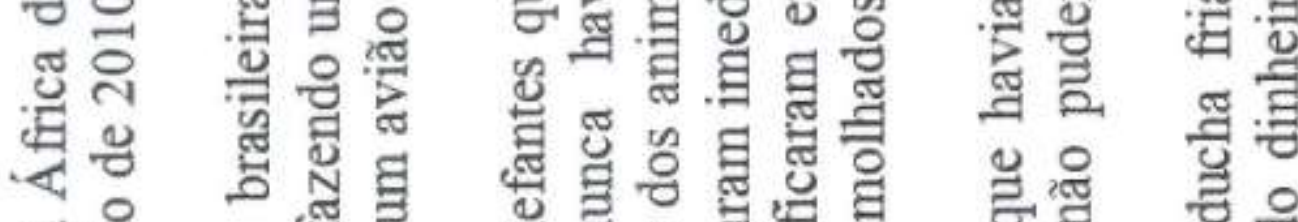

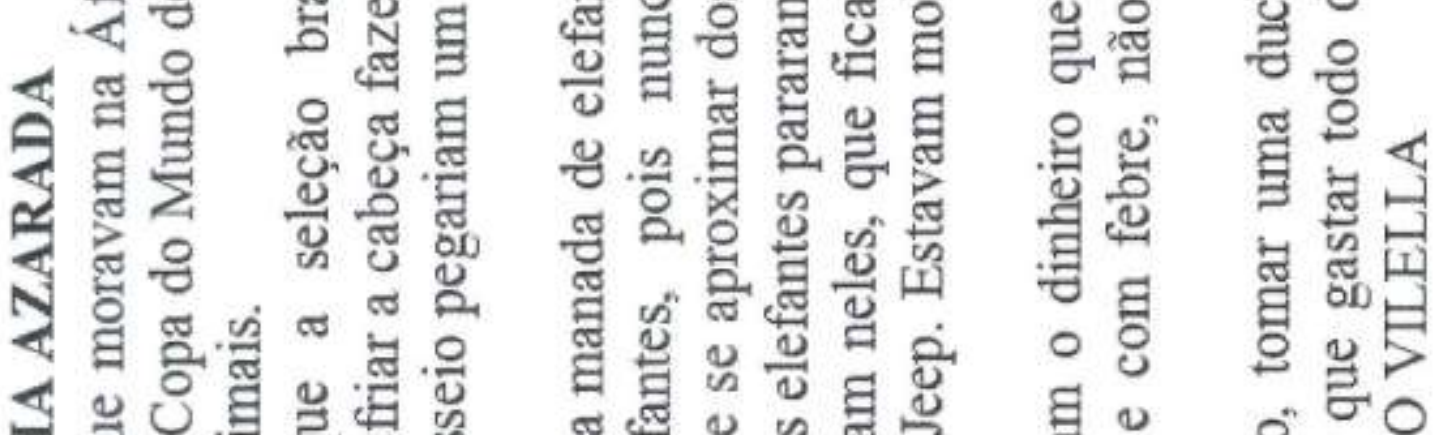

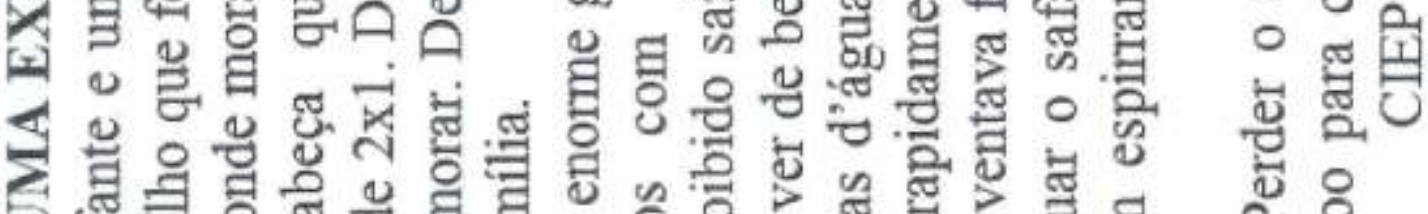

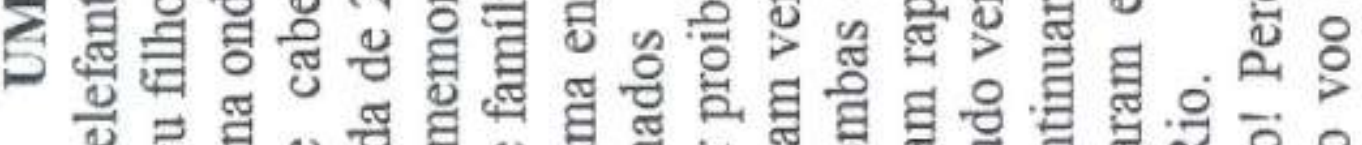

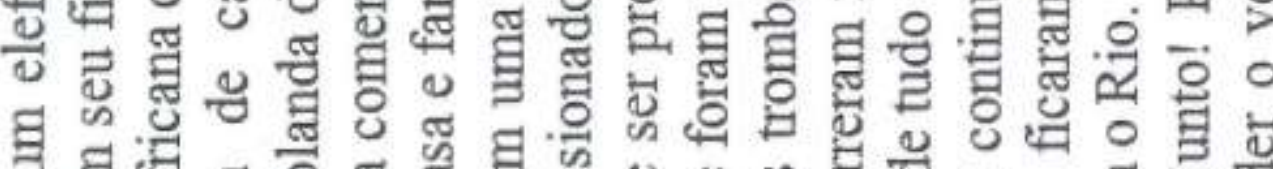

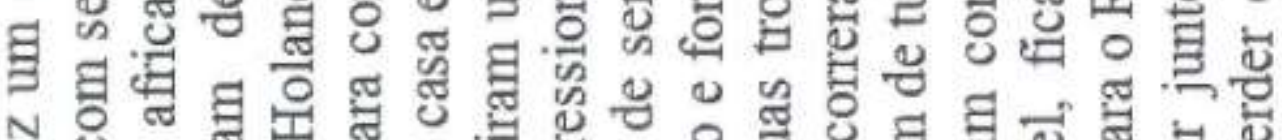
N

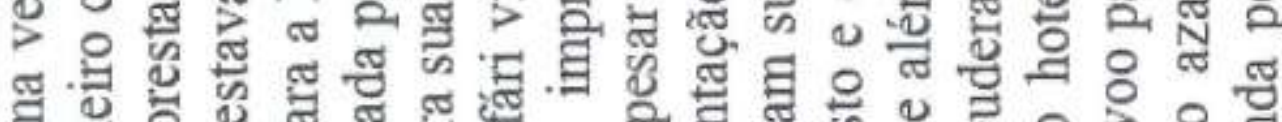

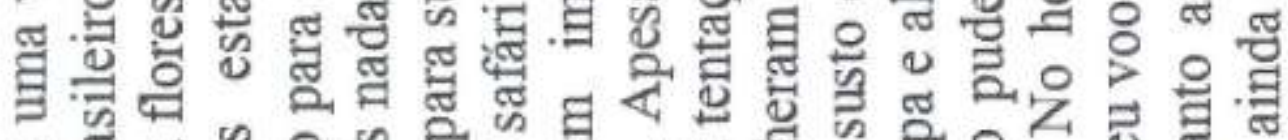

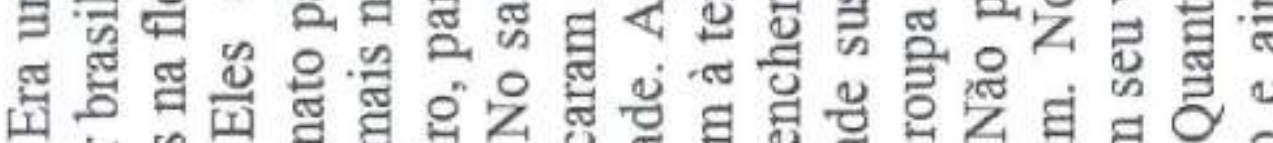

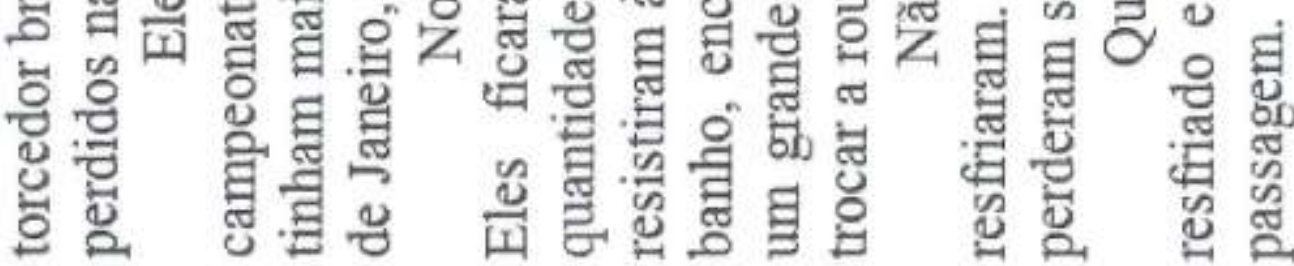

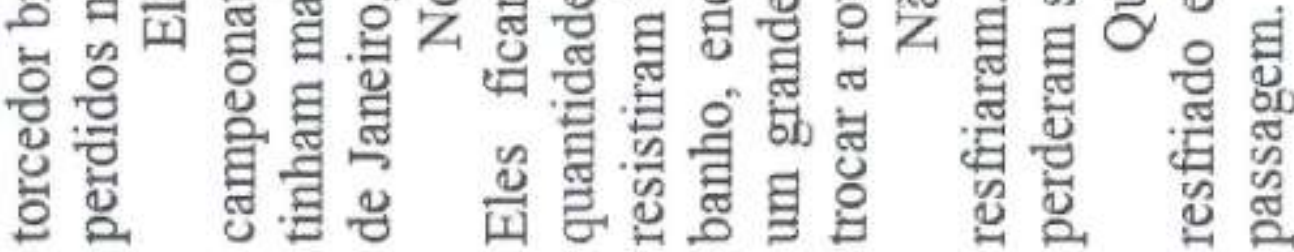




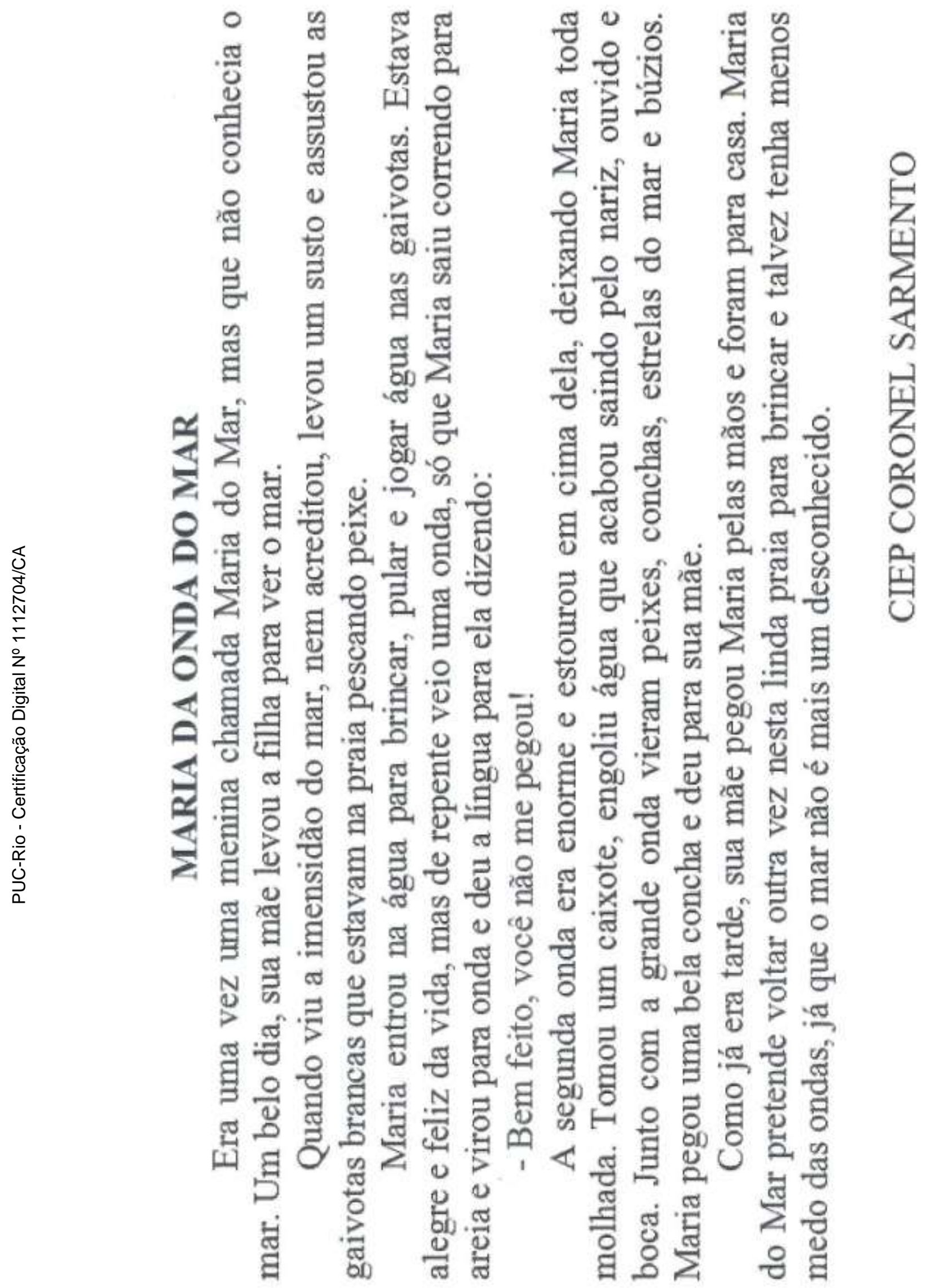




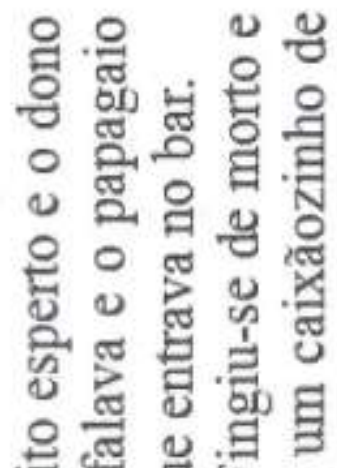

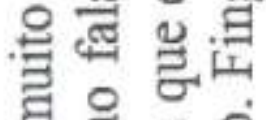

豆 응 官

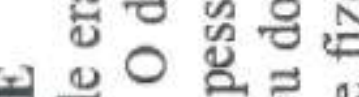

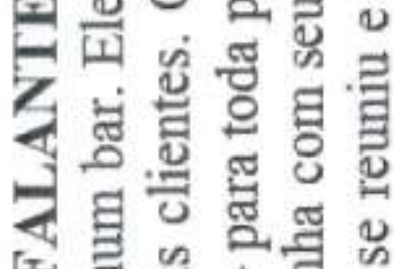

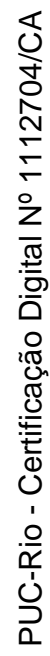

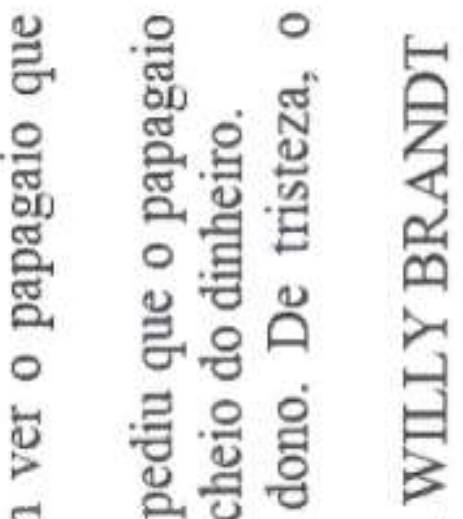

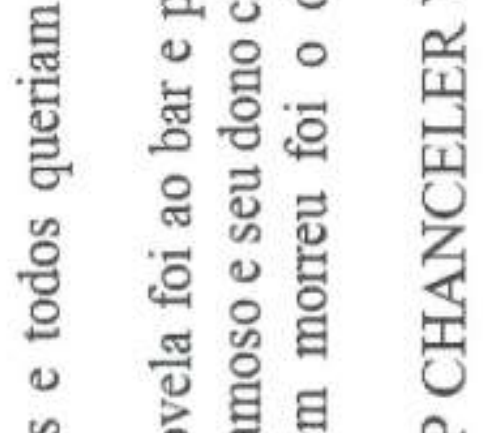

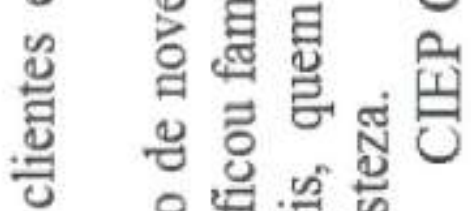

- u

퐁 음

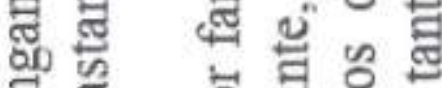
离。 เ 当 自范寻五

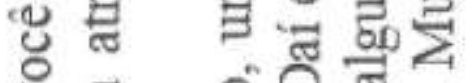
$>$ ช

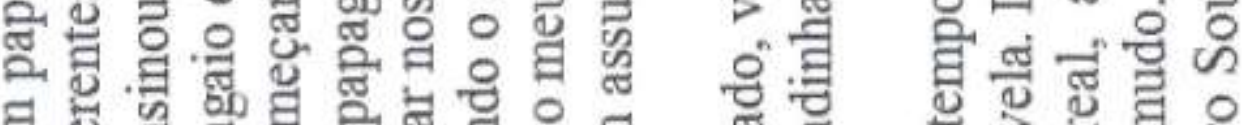

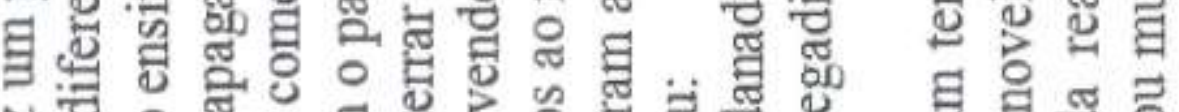

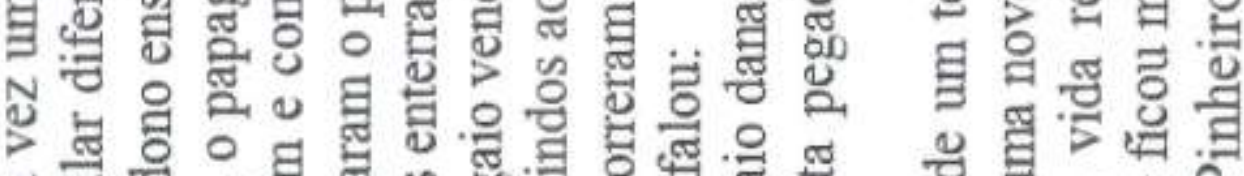

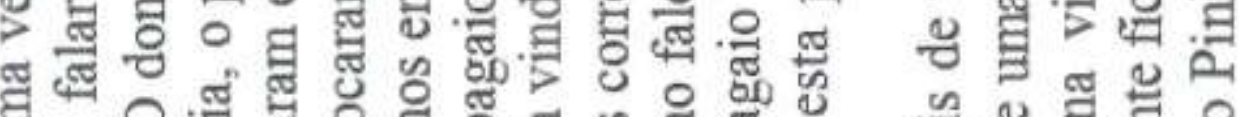
灵 ๘

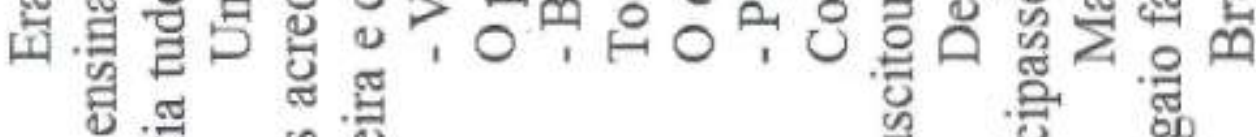

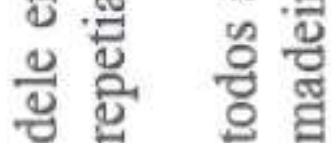




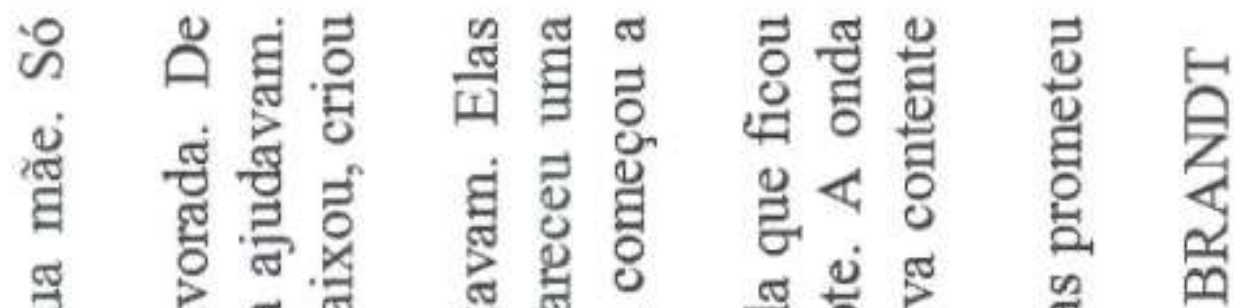

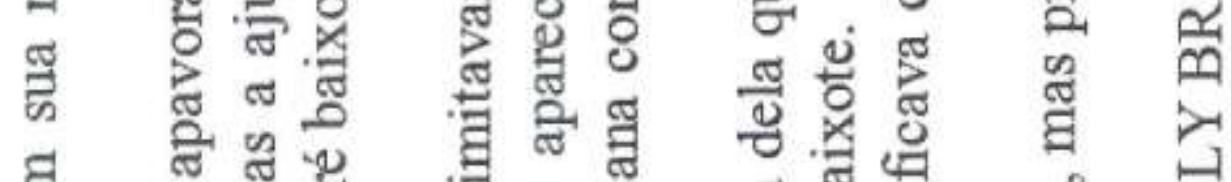

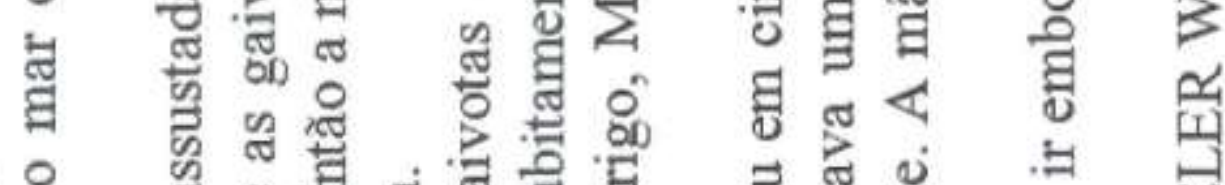

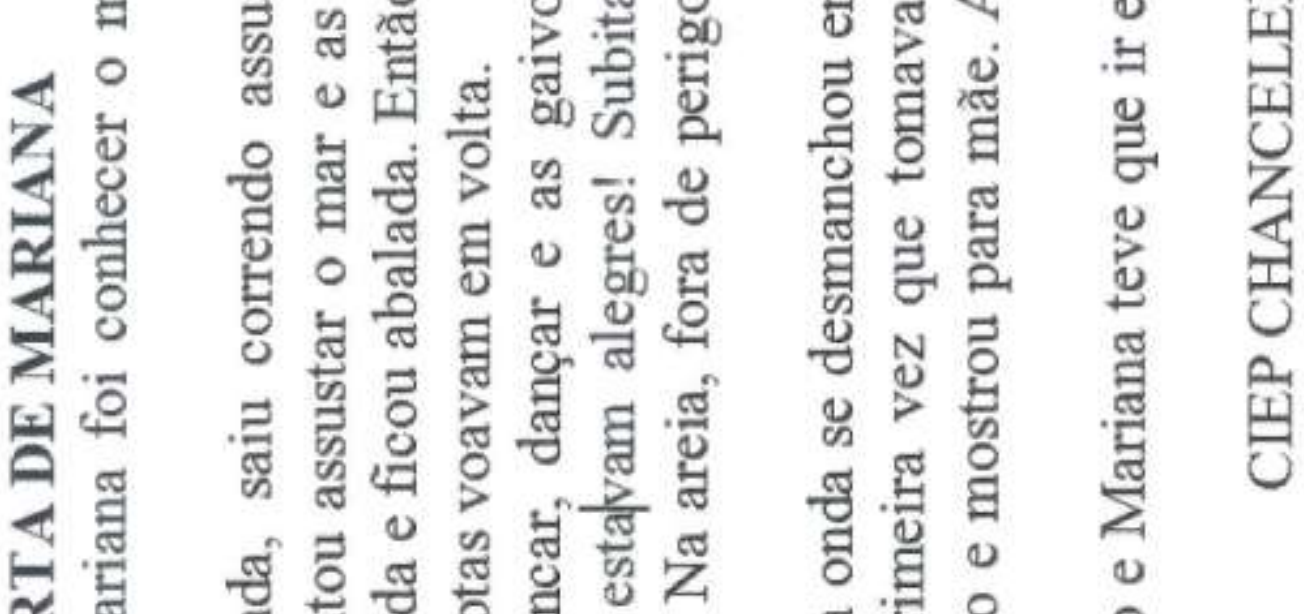

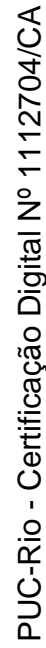

—

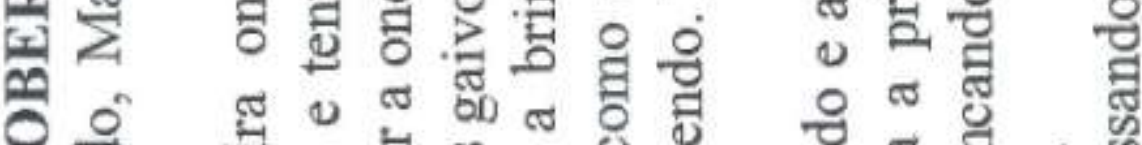

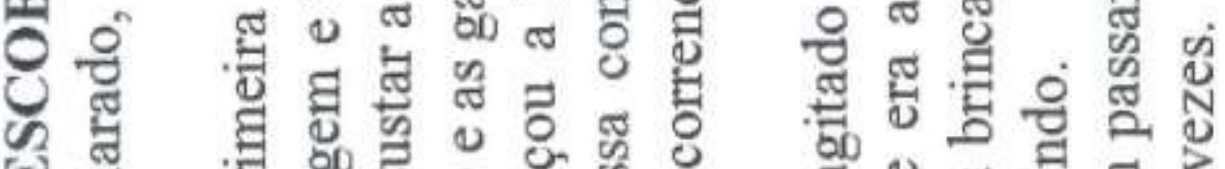

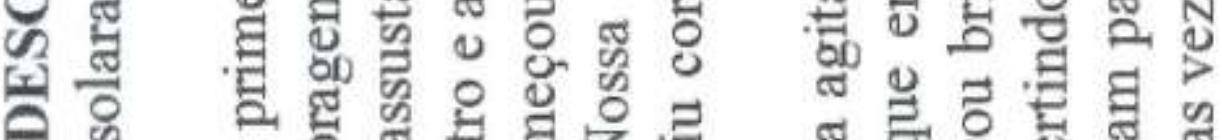

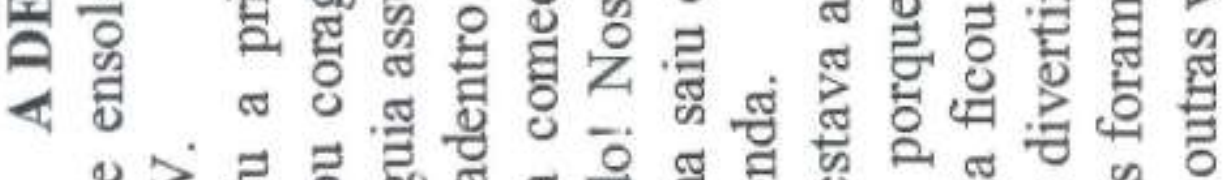

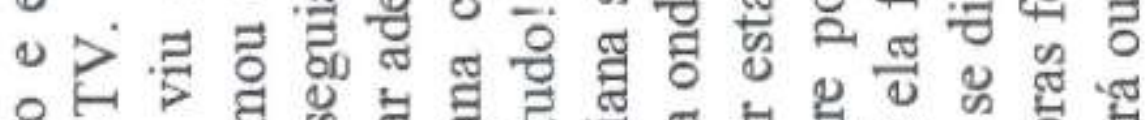

킬

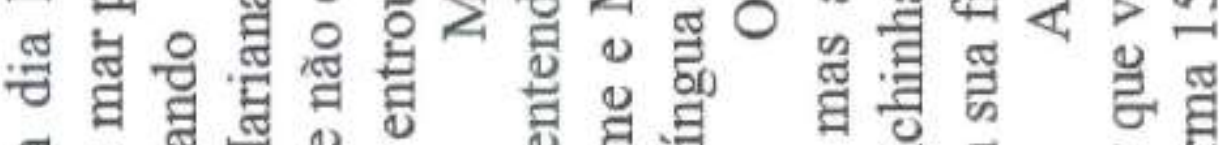

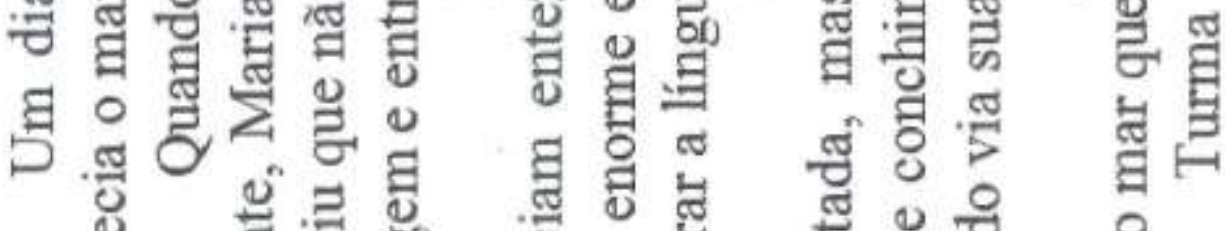

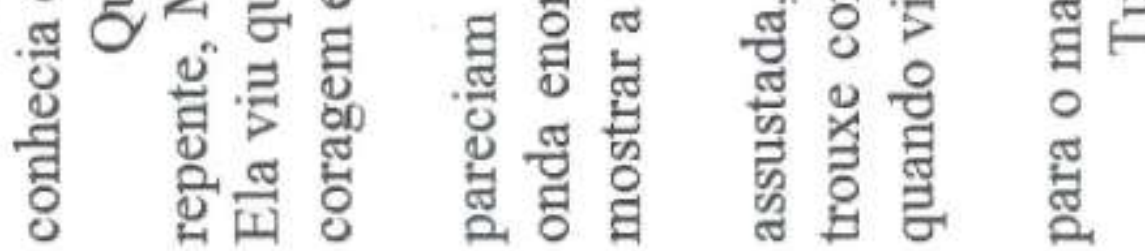




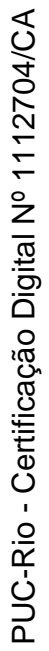

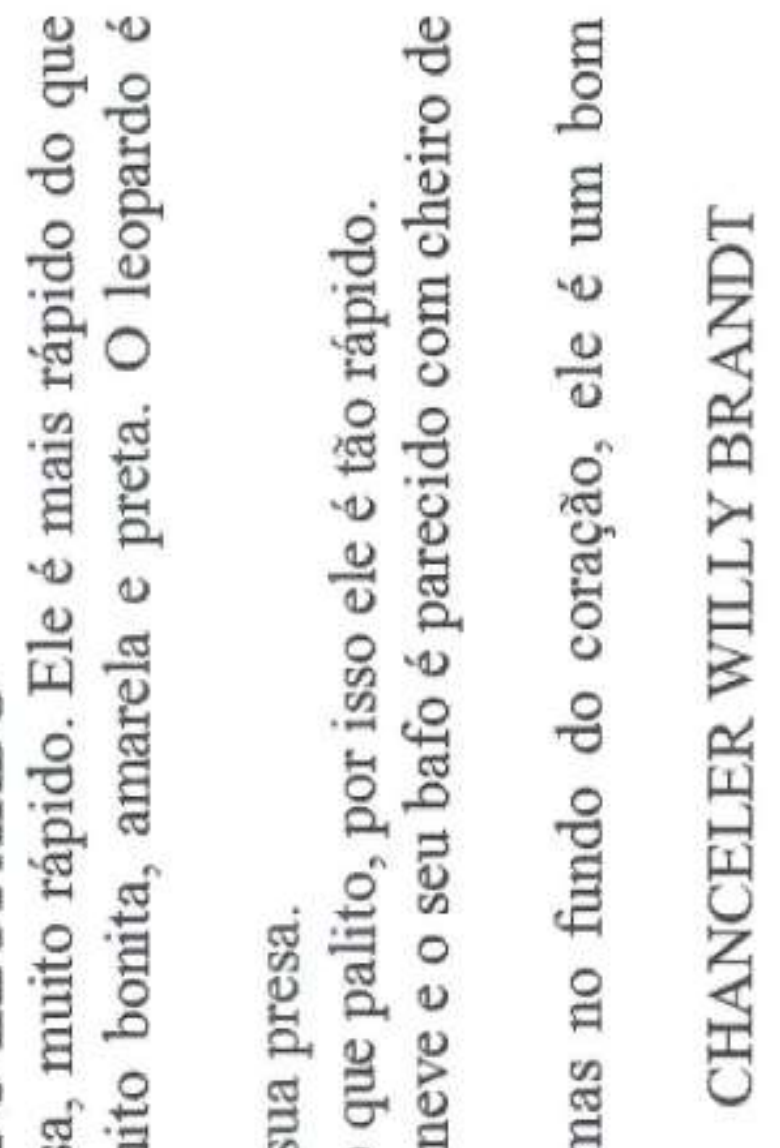

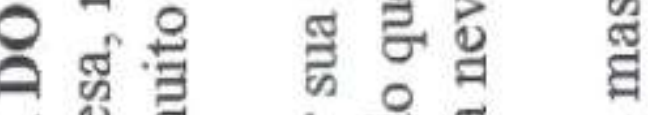

广.

य光出

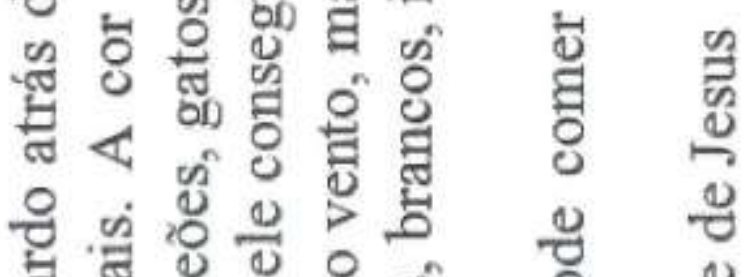

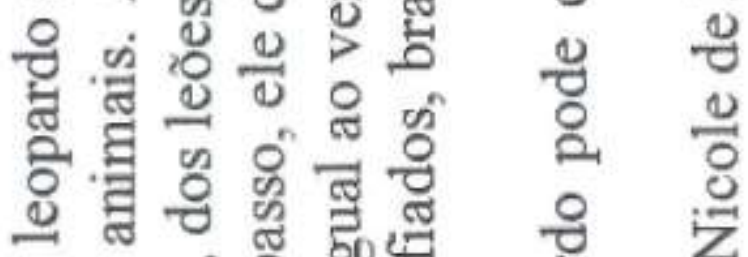

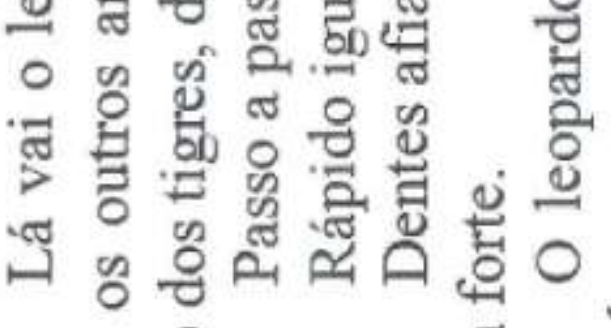

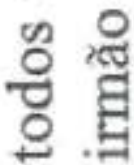

苛 沓 


\section{TEXTOS CORONEL SARMENTO \\ LIVRO CENA DE RUA - ANGELA LAGO}

\section{TEXTO 1}

Era uma vez um menino que vendia ovos coloridos e ficava nos sinais de trânsito das ruas vendendo.

Ofereceu para um senhor:

- Bom dia, senhor! Quer comprar ovos coloridos?

O senhor respondeu:

- Eu não quero isso, sai... Sai daqui, garoto chato!

O menino olhou para dentro de um carro e viu um pitbull latindo:

- Au, au, au, au...

Andou pelas ruas, ai uma mulher pegou um ovo colorido.

O menino disse:

- Tire a mão dai!

Fica triste, o pobre coitado. Ele lutou, lutou para conseguir dinheiro e nada...

Chegou um carro com um velhinho bem rico, mas logo fechou o vidro e não queria nada. O garoto nem podia falar. Passou para o próximo carro, que tinha uma moça brincando com um neném. Ela nem olhou para o menino com seus ovos...

Então ele resolveu comer os ovos coloridos e deu um para o cachorrinho que apareceu do meio do trânsito.

Num carro, viu alguns presentes e resolveu pegar um: Zapt, zupt. As pessoas dos outros carros começaram a olhar. Ele correu e se escondeu, ao abrir viu que eram ovos coloridos e recomeçou a vender.

\section{TEXTO 2}

Em uma bela manhã, João foi vender suas frutas pelas ruas da cidade, quando de repente o sinal fechou e o carro parou em sua frente. Ele ofereceu para vender suas frutas. O senhor falou:

- Sai seu moleque intrometido!

Ele bateu no vidro e os cachorros começaram a latir - au, au, au ... 


\section{TEXTO 3}

Num sinal, cheio de carros parados, um garoto, que se chamava Rodrigo, vendia frutas para ajudar sua familia.

Um motorista ao,ouvir o menino gritando, ficou furioso, porque não queria comprar fruta alguma. Rodrigo estava chateado porque não tinha vendido quase nada naquele dia.

Nos outros carros, cães latiam ferozmente e assustaram o menino que saiu correndo, mas não desistiu. Quando foi para outro carro, uma pessoa má pegou uma de suas frutas sem pagar. No carro da frente, uma senhora velhinha fechou o vidro e deixou Rodrigo falando sozinho. Depois foi até outro carro, onde havia uma mãe brincando com seu filhinho e nem deu atençăo para ele. Dai abre o sinal e todos os carros vão embora.

Num carro, dois homens ficaram impressionados vendo o menino que sentado na calçada comendo uma das frutas, já que a fome era tanta e não tinha dinheiro para comprar comida. Chega perto dele, um cachorro faminto e Rodrigo, cansado, depois de um dia inteiro sem conseguir vender, resolve dar a fruta que sobrou para o pobre cão. 


\section{ESCALADA INESQUECIVEL}

Vivia numa cidade cheia de montanhas, em que algumas eram pontos turísticos. Cada uma era mais bonita do que a outra e ficava dificil decidir em qual iria primeiro, pois cada uma tinha seu encanto especial.

Houve uma gincana chamada Dominó em que as pessoas desempregadas se cadastravam num site e eram sorteadas para participar. Somente oito pessoas poderiam competir, quatro mulheres e quatro homens.

As pessoas escolhidas para o domingo passado foram Diana, 30 anos, moradora da Baixada Fluminense; Pedro Henrique, 29 anos, morador de Copacabana; Viviane, 35 anos, ex-vendedora do Boticário do centro; Luis Fernando de 23 anos, morador do Borel, motoboy desempregado; Michelle, 26 anos, trabalhava no Norte Shopping; Yara, 25 anos, ex-secretária da prefeitura; João Paulo, 33 anos, expizzaiolo na Tijuca e finalmente Carlos, 40 anos que executou diferentes tarefas no comércio.

A grande vencedora foi Yara, que conseguiu alcançar 16 pontos e agora teria que escolher qual ponto turistico iria visitar, pois esse era o prêmio. Fícou numa grande dúvida porque conhecer Pão de Açúcar, Pedra da Gávea, Cristo Redentor ou Pedra Bonita seria tudo de bom, mas só podia escolher um lugar. Qual seria esse lugar?

Yara, depois de muito pensar, ver fotos, curtas sobre as famosas montanhas do Rio de Janeiro, escolheu subir a Pedra Bonita. Queria ir escalando e pediu para ser acompanhada por um experiente alpinista, pois nunca havia escalado e sabia que era dificil.

No domingo seguinte, Yara foi ao programa Sílvio Santos para receber o prêmio. Ficou combinado que o alpinista Marcelo Costa passaria bem cedo na casa de Yara para irem para Pedra Bonita. Seria então, na próxima sexta-feira, dia 13 de agosto, o que deixou a mãe de Yara um tanto preocupada. Ela era supersticiosa e acreditava em Curupira, Saci, loura do banheiro e mula sem cabeça. Vivia sempre cheia de medo de que um deles aparecesse. Pensou que não era de muito boa sorte fazer um passeio tão perigoso numa sexta-feira treze e menos ainda no mês de agosto, mês povoado pelos monstros do folclore, mas Yara nâo mudou a data e achou tudo muita besteira.

Marcelo Costa esqueceu de avisar para Yara usar tênis especial para escalada. Depois de um longo tempo de caminhada, Yara tropeçou numa pedra e torceu o tornozelo o que fez com que subissem mais devagar. Nem mesmo com um pouco de dor, Yara deixou de olhar e aproveitar as belezas da natureza que da Pedra Bonita ia avistando.

Já passava de meio dia e o céu ficou nublado e ainda faltava muito para chegar ao topo. Marcelo começou a se preocupar porque parecia que iria chover, não podiam andar mais depressa por causa do tornozelo da moça e receava pegar noite.

- Yara, será que não podemos voltar noutro dia? Parece que vai chover e talvez peguemos noite na descida.

- Acho que eu aguento andar mais depressa e dai chegaremos antes de anoitecer. Sonhei tanto com este dia e agora você quer desistir. Afinal, quem ganhou o prêmio, eu ou você? Portanto, vamos até o fim.

A mãe de Yara vendo a mudança de tempo, pensou logo que aquele prềmio poderia ser uma armadilha dos maus que povoam a Terra no mês de agosto. Os vizinhos também ficaram preocupados. 
A chuva começou a cair fininha. Tiveram que se proteger numa espécie de caverna que duas pedras juntas formavam. Não estavam distantes do topo, mas seria perigoso continuar escalando. Se de repente escorregassem, já que estava tudo molhado?

A chuva tinha parado e poderiam prosseguir até lá em cima. Foram escalando com dificuldade, mas chegaram ao topo da Pedra Bonita. Yara ficou maravilhada com a beleza da vista. Sentiu que valeu a pena ter passado por tanta dificuldade e ter ganhado o prêmio. Ela viu pessoas surfando na praia, descendo de para-paint e asa delta, o bairro da Barra da Tijuca inteirinho, as famosas montanhas da cidade do Rio de Janeiro e tantas outras coisas, que ela até perdeu o fôlego. Yara ficou tão alegre que chorou de emoção.

- Eu consegui! Sou uma grande vencedora do jogo do Dominó. Que vista linda! Não cansava de admirar.

Marcelo Costa vibrou junto com Yara. - Uhroo! Uhroo! Mas logo se lembrou que não podiam demorar muito, pois o sol já estava se pondo.

- Que tal descermos de asa delta, vai ser muito mais rápido, divertido e viveremos uma nova emoção? - propôs Yara.

- Acho muito perigoso. Se acontecer alguma coisa ruim, como vou levar você para sua mãe?

- Por favor, vamos Marcelo?! Nada vai acontecer. A sorte está do nosso lado. Não há outras pessoas descendo acompanhados de um guia profissional? É seguro!

- Tudo bem, então vamos arriscar!

Yara é amarrada na asa delta e com um frio na barriga salta da pedra. Ela fica encantada com a paisagem. A experiência de voar como um pássaro, flutuando sobre as árvores, praias e os banhistas. Contente, vibra de alegria. E todos olhavam para cima, vendo os "pássaros" descerem. Era pura emoção. Mas como tudo que é bom, dura pouco, logo chegaram à areia da praia.

A mãe de Yara já estava preocupada com a demora da filha e os vizinhos também. Todos conversavam na rua quando apareceram Yara e Marcelo Costa felizes da vida.

- Yara, o que aconteceu? Demorou muito!!! Aconteceu alguma coisa para tanto atraso?

- Não, mamãe. Deu tudo certo, apesar de ter torcido o pé, ter chovido um pouquinho e ter ficado presa numa caverna. Só que depois de tudo isso, chegamos lá em cima e descemos de asa delta.

- Minha filha, quanto perigo! Mas você foi uma guerreira, foi até o fim como todo vencedor. Que bom que deu tudo certo, mas também poderia ter dado tudo errado... É agosto e você bem sabe dos maus espiritos. Poderia ter caído dentro do mar e ser engolida por um tubarão.

- Ah, mãe! Mas estou aqui, sã e salva e deu tudo certo.

- Claro, seu nome é Yara. Yara é uma sereia, nada de mal poderia ter acontecido com uma sereia tão linda como você! 


\section{BAOBÁ EM PAQUETÁ}

Sofia morava em Paquetá e tínha paixão por uma árvore chamada baobá. Sempre que podia, descansava de baixo dela, na sua sombra.

Uma tarde pensando na origem africana do baobá, lembrou-se da lenda de como havia chegado a árvore em Paquetá. A semente, dizem que foi trazida pelos escravos que antes de serem vendidos na Praça XV, ficavam na ilha quando desembarcavam do navio. Lá plantaram o famoso baobá de Paquetá.

Sofia foi ficando cansada e olhando para cima a imensa copa do baobá... E era uma princesa do reino do Mali, estava para se casar com um belo príncipe de um reino distante, chamado Mikael. Havia uma grande movimentação no castelo, os servos preparando sua festa de casamento. Uma enorme festa com muitos convidados importantes vindos de vários reinos da África. A festança duraria o mês inteiro e a população já esperava ansiosa pelos noivos.

A princesa estava em seu quarto experimentando o vestido de noiva, quando entrou pela janela, um homem todo de preto com um imenso facão na cintura, dizendo que estava ali para levá-la para um grande navio que faria uma longa viagem.

- Eu não vou com você. Vou me casar com Mikael, meu amado príncipe. Não quero viajar para nenhum lugar sem ele.

- É melhor você me acompanhar bem quietinha Sua Alteza, senão eu a matarei.

Sofia ficou muito assustada e vendo que não podia fugir, acabou acompanhando o sinistro homem de preto. Saindo pelos fundos do castelo, viu seu querido baobả e pegou suas sementes como lembrança do tempo feliz que ali viveu.

Ela é levada para um navio negreiro que estava de partida no cais. A princesa foi jogada no porão, um lugar escuro, fedorento, sem espaço algum para se movimentar. Estava entulhado de gente com olhar muito triste. Aí ela se dá conta de que era prisioneira, assim como todos eles.

Depois da partida do navio, descobrem que estão vindo para o Brasil, carregados de sofrimento, pois seriam escravos e trabalhariam num lugar desconhecido. Não tinham idéia de onde ficava o Brasil e nem o tempo que levariam dentro daquele navio para chegar.

No porão do navio não tinha água nem alimento, de vez em quando alguém trazia algo para beber e comer. Muitos não agüentavam a viagem e morriam. Seus corpos eram jogados ao mar e viravam comida de tubarão.

Sofia estava com muita saudade de seus familiares, castelo e noivo. Chorava o tempo todo e alguns a consolavam, mas a princesa estava acostumada com um lindo castelo, comida cheirosa e gostosa, com talheres de ouro e prata e excelentes vinhos. Vivia cheia de jóias e vestidos chiques e agora... O que seria que a aguardava?

Ouviu um barulhinho no bolso e lembrou que tinha trazido sementes do baobá. Acreditava que o baobá de sua casa era uma árvore mágica, pois guardava dentro dela muita água, capaz de matar sede de todos os animais, das crianças e dos adultos. Acreditava que quando ficava perto dela, estaria protegida de todos os perigos e problemas.

De repente, cai uma fruta do baobá na cabeça de Sofia e acorda assustada dando conta de que esteve sonhando ser uma princesa africana que acabou prisioneira e foi quem trouxe a semente daquela árvore à ilha na qual morava. 


\section{LOUCURAS NO DESERTO}

Havia um grupo de biólogos que estavam reunidos para conhecer as maravilhas do deserto do Saara. Eram pesquisadores de várias partes do mundo que partiam da cidade de Ouarzazate no Marrocos que era considerada a porta do deserto, por onde iriam sair em caravana.

Todos os habitantes de Ouarzazate eram muito simpáticos. Sempre recebiam turistas que achavam curioso e desafiante conhecer o maior deserto do mundo. Gostavam de pousar para fotos, mostrar suas casas e costumes. Vestiam túnicas com véus nas cabeças que demonstrava pertencerem à religião mulçumana. Além disso, o véu protegia contra o sol e vento.

O biólogo norte-americano, Martim James, liderava o grupo e junto deles ia um guia que falava inglês e podia ir explicando tudo que iam vendo. No primeiro dia de expedição, que era composta de 15 camelos, 10 biólogos, um cozinheiro, um guia c um fotógrafo, sairam de Ouarzazate por volta das 7 horas da manhã rumo ao misterioso e desafiante deserto do Saara.

Caminharam sempre em frente, sem descanso, durante 3 dias, entre pedras e areia escaldante. Ao final do terceiro dia, eles avistaram uma cidadezinha num oásis e ficaram muito contentes, pois estavam exaustos e queriam água e comida frescas.

O grupo se separou para procurar um abrigo onde pudessem ficar e colocar também os camelos para descansar e beber água. Acabaram se perdendo, pois o guia foi procurar um banheiro.

Estava anoitecendo e toda a população fechava suas casas, porque havia ladrões no deserto que roubavam alimentos e camelos. $\mathrm{O}$ grupo não conseguia achar pouso para ficar e a temperatura estava caindo e começaram a sentir frio.

O líder da expedição estava com febre bem alta. Começou a delirar e subitamente uma curandeira apareceu. Ela usou o poder dos cristais para acabar com todos os males que faziam tremer o corpo de Martim James.

Como a curandeira não falava inglês, apenas podia se comunicar com o guia que finalmente tinha voltado do banheiro.

- Sigam-me até minha morada que darei abrigo por uma noite para todos.

Chegando lá, ela fez uma sopa que continha elementos que faziam adormecer. Todos beberam, somente o fotógrafo não tomou, disse que estava enjoado. Percebendo que todos dormiam, achou que algo muito estranho havia naquele lugar.

Pegou sua câmera, foi tirando fotos de toda casa e arredores, procurando pela curandeira que estranhamente tinha sumido. Quando foi fotografar um objeto que estava numa prateleira, percebeu que se moveu e uma porta secreta se abria. Ela dava para uma escada que descia e levava a um túnel, lá bem no fundo.

Quando ele desceu, viu muito ouro e pedras preciosas e lá bem no fundo, estava a curandeira com uma máscara que a deixava com um aspecto de bem velha $\mathrm{e}$ triste.

Ficou sem entender nada. Seria ela a dona de toda aquela riqueza? Mas não parecia, pois se fosse, estaria com outra cara. Estaria alegre, com belas roupas, jóias e tudo em volta seria cheio de luz e luxo. Que estranho aquilo tudo! - pensou o fotógrafo.

- O que posso fazer dessa tropa agora? Parece que não trouxeram nem ouro nem pedras preciosas?! Talvez seja melhor matá-los de uma vez antes do amanhecer. - pensou a curandeira. 
Então foi até a cozinha, pegou vários potes de cores diferentes e começou a colocar em uma vasilha, tudo misturado. A cor final ficou parecida com o marrom do café. Ela sai em busca de sua colher de pau, enquanto isso o fotógrafo pega no armário café de verdade e troca com a mistura que estava vasilha.

Quando ela chegou, mexeu e foi colocando na boca de cada um que ainda estava dormindo. Quando ela voltou para seu quarto e deitou para descansar, planejava como daria fim aos corpos no dia seguinte.

Enquanto isso o fotógrafo foi acordando cada um e encaminhou-os para aquela sala secreta. Ficaram muito surpresos vendo tanto ouro e pedras preciosas num lugar que parecia bem simples e em nada demonstrava ser possivel ter tanta riqueza.

Bem cedo, a curandeira acordou, não viu mais ninguém e correu para o salão onde escondia todo seu ouro. Nada tinha sobrado. Tudo havia sido roubado e não conseguia acreditar no que estava vendo.

- O que aconteceu com o meu tesouro? Isso não podia ter acontecido! Saiu rapidamente de lá a procura da expedição. Eles não escapariam com vida do deserto! Jurou para si a terrivel curandeira.

Andavam o mais rápido possível, sem parar nem para comer. Estavam cansados e nada de encontrar oásis ou alguém que pudessem escondê-los. Martim James, conversando com o guia, se perguntava o que fariam com toda aquela riqueza se no deserto, não poderiam comprar nada e o que mais valia naquele momento era sair com vida e encontrar água. Sem ela nem dinheiro, nem ouro, nem nada fazia sentido. Água, a coisa mais preciosa do deserto...

A curandeira se transformou numa bela moça e acampada no deserto, ficou a espera dos biólogos. Oferece abrigo, água e comida e espertamente consegue pegar de volta seu tesouro enquanto todos dormiam profundamente.

No dia seguinte, todos ficaram muito espantados, pois em volta só havia areia, garrafas d'água e comida dentro da tenda. A bela moça havia desaparecido e também todo ouro. Martim James perguntou:

- Será que foi delírio que tivemos por causa do sol quente do deserto? Mas e o tesouro e a curandeira, será que foi imaginação? Quanta loucura!!!

- Imaginaçã̃o não foi não, porque tirei fotos. - afirmou o fotógrafo.

- Não temos mais riqueza, mas temos água e comida suficientes para podermos sair daqui vivos.

- Vamos rumo ao sul, que temos muito pela frente para caminhar. Levantar acampamento imediatamente e partir rapazes! 